\title{
ANÁLISE DO COMPLEXO DENTINOPULPAR EM DENTES SUBMETIDOS À MOVIMENTAÇÃO DENTÁRIA INDUZIDA EM RATOS
}

RENATA BIANCO CONSOLARO

Dissertação de Mestrado apresentada à Faculdade de Odontologia de Bauru da Universidade de São Paulo, como parte dos requisitos para obtenção do título de Mestre em Odontologia, área de concentração em Patologia Bucal.

(Edição Revisada) 


\section{ANÁLISE DO COMPLEXO DENTINOPULPAR EM DENTES SUBMETIDOS À MOVIMENTAÇÃO DENTÁRIA INDUZIDA EM RATOS}

RENATA BIANCO CONSOLARO

Dissertação de Mestrado apresentada à Faculdade de Odontologia de Bauru da Universidade de São Paulo, como parte dos requisitos para obtenção do título de Mestre em Odontologia, área de concentração em Patologia Bucal.

(Edição Revisada)

Orientador: Prof. Dr. Alberto Consolaro 


\section{Ficha Técnica:}

Renata Bianco Consolaro: execução, texto e formatação final.

Alberto Consolaro: concepção, texto, orientação, fotomicrografia e revisão final.

Maria Fernanda Martins-Ortiz: concepção e execução

Tiago Novaes Pinheiro: auxílio na parte experimental.

Prof. Valdir João Afonso: revisão ortográfica e vernacular.

Maria Cristina Felipe Carrara e Valdir João Afonso: apoio técnico-administrativo.

Fátima Aparecida Silveira: apoio técnico-laboratorial.

Marcus e Ana Amélia Thame: serviços de cópias e encadernação.

\section{Consolaro, Renata Bianco}

C765a Análise do complexo dentinopulpar em dentes submetidos à movimentação dentária induzida em ratos.

Dissertação. (Mestrado) - Faculdade de Odontologia de Bauru. Universidade de São Paulo.

Orientador: Prof. Dr. Alberto Consolaro

Autorizo, exclusivamente para fins acadêmicos e científicos, a reprodução total ou parcial desta dissertação/tese, por processos fotocopiadores e outros meios eletrônicos.

Assinatura:

Bauru, 15 de agosto de 2005. 


\section{Universidade de São Paulo}

\section{Faculdade de Odontologia de Bauru}

Al. Dr. Octávio Pinheiro Brisolla, 9-75 - Bauru-SP-CEP 17012-901 - C.P. 73

PABX (0XX14)235-8000 - FAX (0XX14)223-4679

Pos. Graduaglo

e-mail: posgrad@fob.usp.br - Fone: (0XX14)235-8223

\section{FOLHA DE APROVAÇÃO}

Dissertação apresentada e defendida por

RENATA BIANCO CONSOLARO

e aprovada pela Comissão Julgadora em 29 de agosto de 2005.
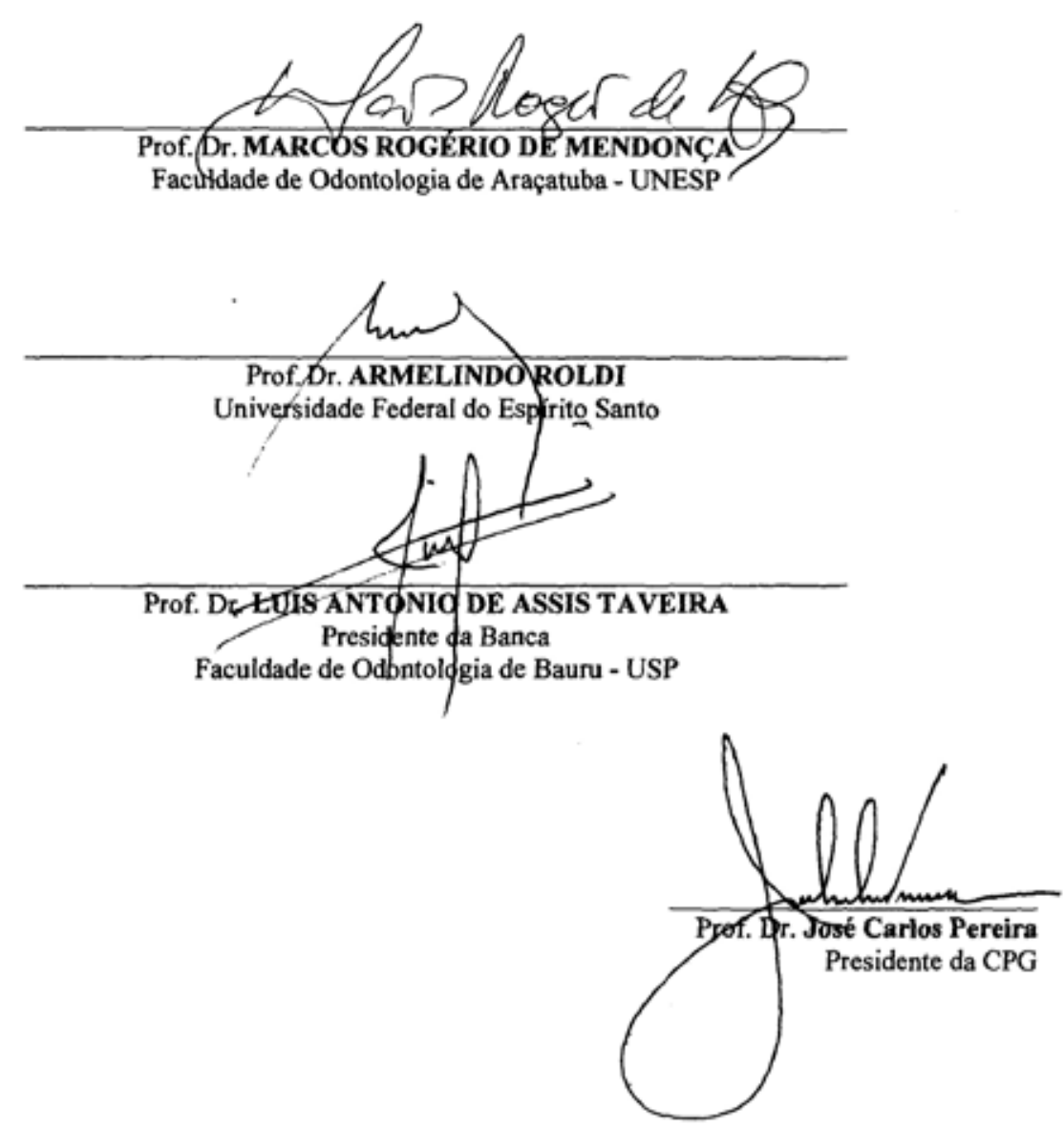


\section{RENATA BIANCO CONSOLARO}

3 de outrubro de 1979

Filiação

$1998-2002$

2002-2004

$2005-$

$2005-$
Nascimento em Presidente Prudente - SP

\author{
Alberto Consolaro e Marisa Silva Bianco
}

Graduação em Odontologia pela Universidade

Metodista de Piracicaba - UNIMEP - em Lins - SP

Curso de Mestrado em Odontologia, área de concentração em Patologia Bucal, Faculdade de Odontologia de Bauru, Universidade de São Paulo.

Professora da disciplina de Patologia da Faculdade Ingá - UNINGÁ, Maringá.

Coordenadora Geral dos Cursos de Pós-Graduação da Faculdade Ingá - UNINGÁ 


\section{Não me interrompam}

Não me interrompam, por favor!

Estou cansado de ser interrompido, de ser bloqueado, farto de sinais vermelhos, sinais para me calar.

Deixem-me falar das minhas vidas e das minhas mortes.

Deixem-me falar dos meus amores e das minhas dores.

Não me interrompam por nada, por favor!

Na minha vida, a interrupção foi uma constante.

Nos estudos, no trabalho, no lazer, na sociedade e na família.

Nos jogos que a vida desafia, no amor, até nas orações,

a interrupção presente, marcando, determinando,

cortando como lâminas afiadas meus caminhos, minhas estrelas.

Por favor, sequer esbocem perguntas, deixem-me falar.

$\mathrm{Na}$ infância, impiedosos, os adultos me interrompiam.

$\mathrm{Na}$ adolescência, professores, sacerdotes, amigos, vizinhos

calavam a minha voz, tolhiam meus movimentos, algemavam-me as mãos, cegavam minha visão,

privavam-me das fontes, negavam-me as ciências.

Homem feito, as interrupções imutáveis, incessantes

ao longo do meu percurso, dos meus espaços.

Por benevolência não me privem da minha bússola.

Não interrompam as minhas manhãs de esperanças

vestidas de verde e amarelo.

Quando atravessar o tempo para abraçar o meu amigo, não interrompam, deixem-me viver as alamedas da amizade.

Não tentem me impedir de embalar o menino de olhos azuis, que me embala com enlevo.

Não interrompam os anjos que me guardam,

a minha estrela guia, o meu pão consagrado.

Não limitem minhas avenidas para o infinito, não reprimam minha voz no meu canto universal.

Deixem-me cantar todas as emoções ocultas 
em minha memória entre flores e abrolhos.

Não interrompam o curso da minha vida,

as minhas quedas, os meus soerguimentos, as minhas mãos espalmadas, os meus braços abertos, os meus risos, meus sorrisos e as minhas lágrimas.

Quando estiver plantando, colhendo e oferecendo flores, não interrompam as minhas mãos abençoadas por pétalas e terras orvalhadas, generosas.

Não interrompam quando estiver navegando com as fadas e os duendes da minha infância.

Não me interrompam quando estiver arando corações, semeando a compreensão e a tolerância.

Por favor, não interrompam o meu amor absoluto!

Quando as nuvens do meu crepúsculo se anunciam, quando o meu verde começa a se descolorir, ainda, ironicamente, me interrompem.

Um funcionário me interrompeu.

Uma criança me interrompeu.

Uma enfermeira me reprimiu.

Um transeunte, desconhecido, me interrompeu.

As manchetes dos jornais interrompem minha paz.

Os noticiários da tv interrompem me agredindo.

Por favor, não me interrompam mais!

Não me interrompam quando estiver chorando por saudade, quando estiver escrevendo meus versos com rimas sem rimas, com angústia, com alegria, com ternura, com amor.

Não interrompam os vôos entre as nuvens das minhas fantasias.

Não interrompam a solidão, minha amante vestida de negro.

Não interrompam meus gestos de paz, não calem minha boca falando de deus!

Por favor, não me interrompam nunca mais! 
As palavras são absolutamente insuficientes para meus sentimentos de gratidão a tantas pessoas que fazem diferença em minha vida. No entanto, deixo registrado meu reconhecimento e gratidão àqueles que contribuíram direta ou indiretamente com este trabalho:

Ao Prof. Dr. Alberto Consolaro, Coordenador do Curso de Pós-Graduação da Disciplina de Patologia Bucal e Chefe do Departamento de Estomatologia, pela oportunidade e pelo privilégio de conviver em tão maravilhoso ambiente e despertar em mim o encanto pela docência.

À Diretoria da Faculdade de Odontologia de Bauru da Universidade de São Paulo e à Comissão de Pós-Graduação pelo apoio recebido. Pela atenção e disponibilidade de seus funcionários.

À Capes, pelo suporte financeiro.

Aos professores da Disciplina de Patologia Bucal: Profs. Drs. Luís Antônio de Assis Taveira, Denise Tostes Oliveira e Vanessa Soares Lara pela contribuição à minha formação profissional, pelo constante incentivo, disponibilidade e amizade.

Aos professores Prof. Dr. Luís Antônio de Assis Taveira pelo desprendimento para entender um sonho de orientação.

Aos funcionários da Patologia, Sr. Valdir, Cristina, Fatiminha, Fernando e Oziel pelo suporte, disponibilidade, mas principalmente pela dedicação e amizade sincera, também compartilhada por seus familiares. Vocês são muito mais que amigos.

Meus singelos agradecimentos a todos os professores do Departamento de Estomatologia que sempre me consideraram, acolheram e ajudaram, especialmente os Profs. Drs. Eduardo Sant'ana, Ana Lúcia Álvares Capeloza e Osny Ferreira Júnior.

A todos da Biblioteca que diariamente nos auxiliam na busca constante do conhecimento, especialmente à Cybele, Valéria, Rita, Vera Boccato, César e Salvador.

Aos funcionários da Faculdade de Odontologia de Bauru, nas pessoas do André da Micro, Camila e Josi da Cirurgia, Vera e Edmauro pela amizade e convivência carinhosa.

Ao Marcus e Ana Amélia Thame pela incrível amabilidade, presteza e excelência na impressão dos exemplares deste trabalho. 
Agradeço a todos os membros da Faculdade Ingá - UNINGÁ, especialmente ao: Dr. Ricardo Benedito de Oliveira, Dr. Roberto de Oliveira, Dr. Washington Rodrigues Camargo, Ney Stival, Paulo Sérgio Barbosa, Gisele Colombari Gomes, Gervásio Cardoso dos Santos, José Felinto e Samile, pela acolhida e confiança.

À Tereza, Laurindo, Bruno e Raquel Furquim pela amizade inconteste, apoio, incentivo e principalmente, pelo carinho da acolhida em Maringá.

Ao querido amigo Prof. Dr. Washington Rodrigues Camargo por confiar em meu potencial e principalmente pela fiel amizade, carinho e incentivo. Sou muito feliz por ser sua parceira de trabalho e poder compartilhar de seus ensinamentos e experiências.

À Tânia Grão Velloso, amiga incondicional, mestre pacienciosa e um exemplo a ser seguido, obrigada por todo o carinho, atenção, compreensão e paciência. Tenho muita sorte de poder ter convivido com você e o Marcelo que deixaram a marca da fidelidade gravada em nossos corações.

À Leda Francischone, Ledinha, pela inestimável ajuda no capítulo de referências, pela alegria, amizade, disponibilidade e cumplicidade constante.

Aos colegas de pós-graduação do Doutorado e Mestrado: Diego, Tânia, João Adolfo, Maria Fernanda, Rosa, Rosário, Marta, Patrícia, Suzana, Leda, Erick, Renata Falchete, Luciana, Renato, Bethânia, Tiago, Lidiane, Camila, Carlos Bettoni, às Éricas, Janaína, Simone e Carol pela convivência alegre e sempre amistosa. Especialmente à Renata Falchete e à Bethânia pelo carinho, amizade, sinceridade e pelas nossas longas conversas.

A minha querida amiga Meirielle Rodrigues, uma verdadeira irmã, pela inconteste amizade, confiança depositada, companheirismo e sinceridade. Por extensão a meu sobrinho de coração Vitor, Vitão, pela alegria e carinho inocentes, a Mariuza e ao André pela acolhida em suas vidas.

À Maria Fernanda, Nana, que de madrasta não tem nada, pela sincera amizade e compreensão. Por desprendidamente compreender e silenciosamente me defender. Você sabe o quanto foi importante no restabelecimento de um complicado e às vezes dolorido relacionamento.

Aos meus avós Luiz e Augusta, tio Zé, tia Diroca, tio Gervásio, meus primos Etiene e Gustavo e tio Luís Augusto obrigado pelo carinho de sempre.

À dona Maria, Seu Jonathas, Dete, Nena, Jú, Paulo e Zé pelo carinho com que me receberam em minha nova família e pelos divertidos momentos, obrigada pela acolhida. 
Ao casal Carlos Eduardo e Maura Bacchi, pela amizade singela e impressionante disponibilidade dedicadas e por viabilizar a obtenção de fotomicrografias tão maravilhosas na Consultoria em Patologia.

À família Esberard, à família Grão Veloso Damato Oliveira, à família Francischone, à família Furquim, amigos do peito que na verdade são meus tios de coração.

As queridas amigas(os) Amanda, Ana Cristina, Júlia e Alexandre, Michelle, Cidinha, Evelin e Luíza pelo carinho, mesmo que distante, e pela perseverança no cuidado de nossa amizade.

Por meus Tios, Tias, Primos e demais parentes pela amizade, alegria e torcida. De modo especial aos queridos (as): tio Roberto, tia Márcia, tio Gervásio e tia Diroca.

Ao Dr. Décio, dona Thereza Maria, seu Maciel e dona Isa, obrigada pela alegria dos momentos de convívio.

Aos animais utilizados neste trabalho, por darem suas vidas em benefício da espécie humana. Que estas mortes em holocausto à ciência não tenham sido em vão.

\section{Dedico este trabalho e agradeço especialmente:}

A Deus pelo dom da vida, pela saúde, pelas oportunidades, pela família e pelos amigos que me concedeu.

Senhor ajuda-me a ser humilde e a viver de acordo com os ensinamentos cristãos. Ajuda-me a amar o meu próximo, não apenas nos momentos simples, mas principalmente quando for mais dificil, reconciliando-me diariamente com todas as coisas do universo.

Tudo que sou é reflexo de meus pais, ancestrais e familiares, jamais serão suficientes meus agradecimentos a Deus por esta fantástica família à que me destinou, por isso agradeço- Lhe, profundamente:

A minha mãe Marisa, minha avó Laís e meu irmão Sílvio por entenderem um sonho, uma necessidade de crescimento e amadurecimento pessoal e profissional, por abrirem mão dos momentos de convívio, que sofreram com minha ausência e que muitas vezes me receberam de mau humor, quase raivosa, quer por minha ausência, por saudade ou por impaciência. A vocês que agora vêem, até com certo alivio, esse fim de mais uma etapa, meu muito obrigado. Eu os amo muito!

Ao meu pai Alberto, por muito me ensinar, e que mesmo a custas de muitos 
desgastes emocionais nunca desistiu de mim, acho que seu esforço e seus cabelos brancos adquiridos valeram a pena! Ao senhor que soube compreender meus limites, mesmo que algumas vezes impacientemente, minha eterna gratidão. Quero que o senhor saiba que mesmo não demonstrando, muito amadureci nesses dois anos, graças a sua orientação. Obrigada por despertar em mim os caminhos da docência e abrir as portas para o meu futuro, iluminando meu caminho com a luz mais brilhante que pôde encontrar. Amo você incondicionalmente!

Ao Fernando, por me amar incondicionalmente e me ensinar a cada dia que compartilhar vale a pena. A você que pacientemente $e$, às vezes, risonhamente, entendeu meus chiliques. Você é o meu grande amor! 


\section{SUMÁRIO}

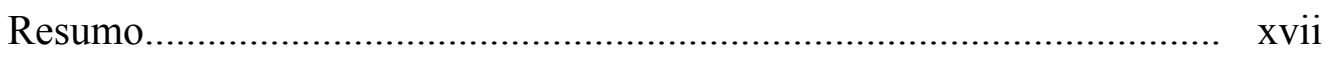

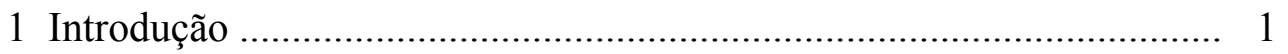

2 Revisão da Literatura ........................................................................ 7

3 Proposição .............................................................................. 31

4 Material e Métodos ....................................................................... 35

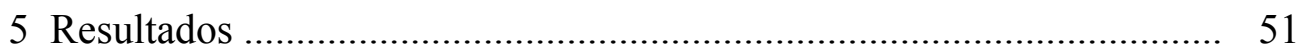

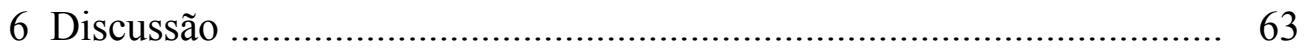

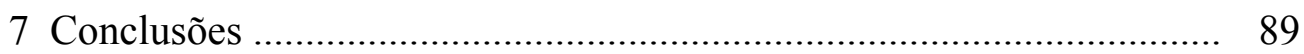

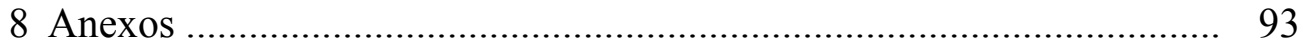

Referências Bibliográficas .................................................................... 107

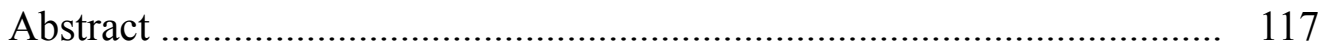




\section{Resumo}

Os efeitos pulpares da movimentação dentária induzida foram analisados na microscopia óptica, em 49 primeiros molares superiores de ratos. O aparelho ortodôntico consistiu em uma mola fechada ancorada aos incisivos superiores, movimentando mesialmente o primeiro molar superior esquerdo. Dez animais foram considerados controle, sem movimentação dentária induzida; os demais foram divididos em grupos de acordo com o período de observação após a movimentação: 1, 2, 3, 4, 5, 6 e 7 dias. A eficiência da força e comprovação do movimento dentário teve como parâmetros as alterações periodontais, incluindo-se hialinização segmentar, reabsorção óssea frontal e a distância e a reabsorção radicular. No complexo dentinopulpar não foi observada qualquer alteração morfológica que indicasse efeito da movimentação dentária induzida. 


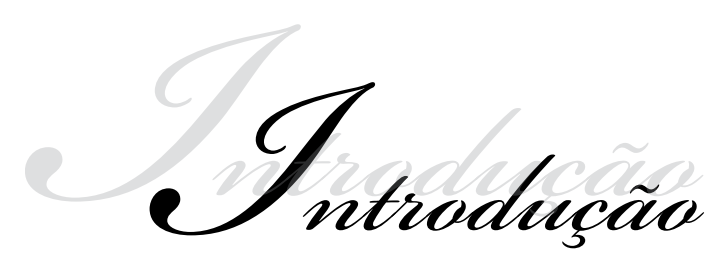




\section{Introdução}

A polpa e os tecidos periodontais são tecidos dentários moles ricamente celularizados e com índices metabólicos adaptados às suas necessidades funcionais. Mas, parece lógico que esses tecidos possam ser influenciados em sua normalidade estrutural e funcional por alguns fatores locais e sistêmicos. A detecção clínica ou o aparecimento de alterações induzidas na polpa e nos tecidos periodontais pelos fatores locais e sistêmicos, provavelmente, dependem do tipo, duração e intensidade desses fatores.

A avaliação do estado pulpar e sua relação com fatores locais e sistêmicos podem gerar conhecimentos que nos levem a diagnósticos precoces, procedimentos preventivos, mudanças ou eliminação de certas condutas ou até mesmo a criação de protocolos de controle. Mas, apesar disso, a freqüência e os perfis clínico, imaginológico e microscópico das possíveis alterações pulpares associadas a certos fatores locais, como a movimentação ortodôntica, ainda não foram evidenciados de forma clara e definitiva.

O objetivo principal deste trabalho concentrou-se em colaborar para o esclarecimento de algumas das mais freqüentes dúvidas envolvendo a polpa dentária.

1. O movimento dentário induzido pode promover o envelhecimento precoce da polpa, mesmo quando apenas observada microscopicamente?

2. O movimento dentário induzido com finalidade ortodôntica promove pulpites, mesmo que transitórias?

3. E necrose pulpar? 


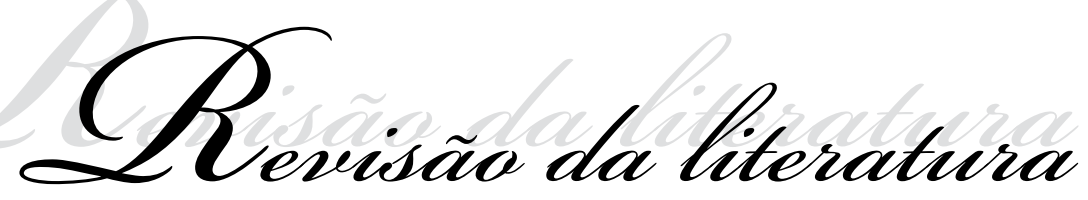




\section{Revisão da literatura}

Este capítulo apresenta uma revisão da literatura submetida a uma análise crítica sobre a relação da movimentação dentária induzida e o complexo dentinopulpar. Esse assunto pode ser considerado controvertido por duas razões:

a) a literatura pertinente não é ampla e os trabalhos, de um modo geral, apresentam metodologia e design experimental passíveis de questionamentos ${ }^{13,59,91,94,103}$.

b) os trabalhos apresentam aspectos indesejáveis relacionados às prováveis iatrogenias, gerando conflitos de interesses ${ }^{17,74}$.

Apesar das alterações vasculares apresentadas como conseqüentes da movimentação ortodôntica, uma relação precisa, com base em parâmetros bem definidos ainda não foi devidamente esclarecida, pois, nega-se a possibilidade de necrose pulpar ocorrer sob essas condições clínicas. Trabalhos mais antigos, porém, sugerem, quase que opinativamente, que as alterações vasculares promovidas pela movimentação ortodôntica levariam à necrose pulpar. Nesta revisão criteriosa e analítica da literatura pertinente, cronologicamente, vamos discorrer sobre todos esses trabalhos para embasar nossa discussão dos resultados obtidos neste estudo experimental.

Em 1936, 1937 e 1942 Oppenheim ${ }^{66,67,68}$ descreveu que dentes submetidos à movimentação ortodôntica apresentavam atrofia eventual da polpa com atresia do canal radicular quando observados radiograficamente. Microscopicamente, havia aumento dos fibroblastos e das fibras colágenas em toda a polpa com infiltração de células inflamatórias redondas na porção coronária. Descreveu, ainda, redução numérica dos vasos sangüíneos, constrição dos mesmos e rompimento focal da camada odontoblástica. Essas alterações estavam condicionadas à intensidade das forças. As alterações na camada odontoblástica aconteciam, principalmente, na região contralateral da polpa, onde havida sido aplicada a força, sendo que a principal alteração pulpar era a sua "degeneração". 
Em seu livro sobre Ortodontia (1943), Strang ${ }^{98}$ expressa sua opinião: as forças súbitas de tensão em um dente podem lesar os vasos da polpa coronária e provocar uma congestão venosa com necrose pulpar. Também forças intrusivas intensas podem impedir o suprimento arterial e levar a perda da vitalidade pulpar.

Em 1951, Butcher e Taylor ${ }^{12}$ apresentaram um estudo em que a polpa do incisivo inferior de macacos com forame apical aberto foi destruída por exuberantes forças retrativas. Essa força retrativa foi aplicada por elásticos próximos às bordas incisais e ligados a um arco que, de forma circunferencial, passava por toda a mandíbula na altura da sínfise. Essa perda da vitalidade pulpar foi atribuída à morte da polpa como resultado da perda da vascularização.

Os mesmos autores, Butcher e Taylor ${ }^{11}$, em 1952, utilizaram-se de uma quantidade não revelada de macacos Rhesus, com incisivos permanentes em fase préeruptiva, com forame apical ainda aberto não completamente formado e ainda ápices com forame fechado. Após aplicarem as forças retrativas de $250 \mathrm{Gm}$, injetava-se via intravenosa carvão da Índia para marcar os vasos sangüíneos. Para os autores, a força aplicada nos dentes com ápices incompletos estrangulavam as veias da polpa e provocava estase após 72 horas, dificultando a drenagem sangüínea da polpa. Para os autores, "indubitavelmente", havia duas vias de alteração pulpar: alteração das artérias e congestão venosa. No osso alveolar apical, havia alterações que indicavam reabsorção e até necrose pulpar. Alguns dentes foram submetidos à retração até por 10 a 20 dias.

Para os autores deste mesmo trabalho, nos dentes com forame apical pequeno e ápice completamente formado, as alterações eram bem mais leves, pois, o ápice não tocava o osso alveolar. A explicação dada sugere que o melhor suporte periodontal promovido por fibras completamente aderidas e um ligamento completamente formado não deixariam ocorrer esta compressão vascular pela ancoragem estrutural proporcionada. 
Nesse trabalho: 1) as numerosas fotomicrografias não revelam a necrose pulpar; descrita para alguns casos; 2) as alterações ósseas descritas no osso alveolar apical correspondem à morfologia óssea própria do alvéolo em formação durante a rizogênese; 3) os dentes ditos com ápices abertos, verdadeiramente, eram dentes em franca rizogênese incompleta contendo nos cortes apresentados bainha de Hertwig, papila dentária e folículo dentário. As alterações encontradas foram detectadas apenas nessa situação de desenvolvimento dentário, mas não nos dentes com ápices completamente formados; 4) o número de animais, de dentes e os critérios de análise não foram revelados; 5) o tipo de aparelho e o modo de instalação não estavam fotograficamente apresentados. Em suas conclusões, os próprios autores reconheceram que as evidências são frágeis para sugerir que forças utilizadas em movimentos ortodônticos de retração com inclinação possam ser suficientes para estrangular a árvore circulatória da polpa, pois, as forças utilizadas no trabalho não seriam comparáveis ao da clínica ortodôntica e não seriam suficientes para provocar necrose pulpar.

Ao revisar os aspectos fisiopatológicos das reações pulpares frente aos irritantes, Brannstrom $^{8}$, em 1967, afirmou que o suprimento sangüíneo é um importante fator nas reações pulpares. Para ele, o suprimento sangüíneo pulpar não difere dos vários outros tecidos conjuntivos nos quais constitui um fator significante nos mecanismos reacionais inflamatórios e hidrodinâmicos. Nesse seu trabalho, apesar de abordar numerosos irritantes pulpares, em nenhum momento, mencionou o movimento dentário.

Em 1969, Mjör e Stenvik ${ }^{60}$ estudaram as alterações da polpa e dentina após a intrusão experimental em 20 pré-molares humanos jovens, com ênfase na distribuição do seu conteúdo orgânico. Aplicaram forças que variavam de 30 a $250 \mathrm{~g}$ e utilizaram como método de observação a radiomicrografia. Detectaram vacuolização odontoblástica e pré-dentina mais densa no grupo experimental, muito embora esses fenômenos fossem notados no grupo controle. Também relacionaram discretas áreas hemorrágicas e perda de continuidade do endotélio como efeitos da intrusão experimental. 
Surpreendentemente, vários estudos foram publicados e relataram reações da polpa, pré-dentina e dentina após a movimentação ortodôntica. Fischer27,1933; Kogure et al. ${ }^{43}$, 1933; Marshall ${ }^{52}, 1933$; Oppenheim ${ }^{67,69}, 1936$ e 1942; Butcher e Taylor ${ }^{11,12,1951}$ e 1952, além de outros, indicaram que o tratamento ortodôntico leva a alterações circulatórias, degeneração pulpar, calcificações e até mesmo necrose. Entretanto, o material apresentado nessas publicações é muito limitado e nenhum trabalho recente ou extensivo avaliou essas reações detalhadamente. Nesses estudos, utilizaram forças excessivas que, se aplicadas em um tratamento ortodôntico, gerariam resultados indescritiveis; esses trabalhos parecem considerar que as forças usadas no tratamento ortodôntico não têm limites em sua magnitude. Essas frases foram extraídas de Stenvik e Mjör ${ }^{96}$ quando, em 1970, propuseram-se a estudar as reações iniciais pulpodentinárias na intrusão. Utilizaram 35 dentes hígidos de crianças entre 10 e 13 anos intruídos com forças de 35 a 250g em aparelhos fixos em condições controladas por 4 a 35 dias. Todos os dentes foram extraídos logo após a remoção da força aplicada. Um mesmo número de dentes não tratados foi utilizado como controle.

As principais alterações detectadas por Stenvik e Mjör ${ }^{96}$ (1970) foram vacuolização do tecido pulpar e distúrbios circulatórios, quase sempre representados pela estase. Os dentes com ápices completos exibiram alterações mais severas que os dentes com ápices abertos. A magnitude da força foi um fator importante. Os dentes com desenvolvimento radicular incompleto apresentaram freqüentes distúrbios na formação da raiz. Não houve infiltrado inflamatório nas polpas examinadas. Comparando-se o número e a morfologia dos nódulos pulpares, entre o grupo experimental e o de controle, os autores não detectaram diferenças. Reabsorções radiculares nas faces laterais do ápice foram diagnosticadas microscopicamente em $60 \%$ dos dentes movimentados.

As alterações microscópicas da polpa foram encontradas por esses autores em ambos os grupos, embora no grupo controle, em apenas três dentes, essas alterações 
foram consideradas como severas. Destacaram ainda que: a) a principal alteração encontrada nas polpas foi a vacuolização odontoblástica; b) as alterações eram significantes maiores na porção coronária das polpas examinadas com diminuição gradativa à medida que se chegava ao ápice; c) a magnitude da força não se relacionava com a severidade das alterações microscópicas observadas. Os autores descreveram ainda que no grupo experimental houve redução da camada de pré-dentina.

Nas fotomicrografias apresentadas por Stenvik e Mjör ${ }^{96}$ (1970), podemos notar que as alterações vacuolares observadas na polpa decorrem de dificuldades do fixador chegar às partes mais periféricas e distantes da polpa via canal radicular. Essa possibilidade de alterações representadas pela vacuolização serem artefatos de técnicas foi abordada e admitida na discussão do trabalho. Isso também pode explicar porque os dentes com ápices completos apresentaram alterações mais severas que os com raízes incompletamente desenvolvidas.

Outros 25 dentes foram examinados por Stenvik ${ }^{95}$ em 1969, sob a mesma metodologia e objetivos, agora, priorizando as reações tardias da polpa sob forças intrusivas. Encontraram as mesmas alterações descritas anteriormente, mas, com menor magnitude e com diferenças também sutis entre o grupo experimental e o grupo controle. A alteração mais valorizada continuou sendo a vacuolização odontoblástica, embora relatassem a diminuição da camada de pré-dentina. Para o autor, quanto maior a vacuolização odontoblástica encontrada, menor era a camada de pré-dentina. O autor afirmou ainda que suas observações corroboraram com a de outros autores e continuou dizendo que alterações pulpares são mais significantes em dentes com rizogênese incompleta submetidos à intrusão do que quando têm os ápices completos.

Do primeiro trabalho de 1970, Stenvik e Mjör ${ }^{96}$ acabaram por denominar os 35 dentes de grupo experimental 1; os outros 25 dentes do segundo trabalho de 1970, acabaram por serem denominados de grupo experimental 2. Dessa forma, publicaram um terceiro trabalho reunindo esses resultados. 
Um ano depois, Stenvik e Mjör ${ }^{97}$, em 1971, propuseram-se a estudar as reações pulpodentinárias na intrusão em 60 dentes. No grupo experimental 1, formado por 35 dentes hígidos de crianças entre 10 e 13 anos, foram aplicadas forças intrusivas de 35 a 250Gm em aparelhos fixos, em condições controladas por 4 a 35 dias. Todos os dentes foram extraídos logo após a remoção da força aplicada. Um mesmo número de dentes não tratados foi utilizado como controle. No grupo experimental 2, formado por 25 dentes, em iguais condições, também se aplicaram forças intrusivas, mas de 50 a 250 gramas por 4 a 104 dias. Nos dentes com rizogênese incompleta, houve alterações na bainha de Hertwig e raízes malformadas, maior número de canais acessórios e modificações na microscopia dos tecidos apicais. Notaram também um aumento de ilhotas epiteliais pulpares e de nódulos pulpares verdadeiros. As reabsorções foram freqüentes nas porções laterais do ápice radicular.

As principais alterações detectadas por Stenvik e Mjör ${ }^{97}$, no trabalho de 1971, foram estabelecidas nos dentes completamente formados e eram de natureza degenerativa e não inflamatória, pois, não detectaram infiltrado inflamatório nas polpas examinadas. Notaram a vacuolização do tecido pulpar, reconhecida pelos autores como um provável artefato de fixação tecidual. Os distúrbios circulatórios quase sempre representados pela congestão vascular, estase e pequenas áreas hemorrágicas. Áreas hialinas perivasculares também foram relatadas. Comparando-se o número de nódulos pulpares no grupo experimental e controle não detectaram diferenças, apenas um número maior de dentículos verdadeiros nos dentes com rizogênese incompleta. Para os autores, as alterações encontradas são transitórias.

Ainda em 1971, Landay e Seltzer ${ }^{47}$ propuseram estudar os efeitos pulpares de forças oclusais excessivas e do movimento dentário induzido em ratos a partir de 4 tipos diferentes de modelos experimentais. Após uma confusa apresentação de seus resultados, concluíram que novos estudos precisavam ser realizados, visto que, em suas observações, não encontraram efeitos pulpares induzidos por forças oclusais excessivas e pelo movimento dentário induzido. 
Na expansão rápida do palato, Timms e $\mathrm{Moss}^{100}$, em 1971, investigaram, microscopicamente, as modificações pulpares e observaram deposição de dentina secundária e a freqüência de nódulos pulpares.

Em dentes de cães movimentados, em 1972, Anstendig e Kronman³ observaram, microscopicamente, as reações pulpares, especialmente dos vasos, em resposta a forças ortodônticas aplicadas. Foram utilizados seis cães, nos quais foram movimentados apenas os incisivos inferiores, sendo que em três obteveram movimentos de inclinação, nos outros três, movimentos de corpo. Os dentes movimentados foram descritos com maior número de elementos fibrosos na polpa, degeneração da camada odontoblástica e diminuição do número de vasos sangüíneos. Destaca-se, na análise desse trabalho, que os cães não apresentavam raça, idade e origem definida. As alterações mais significantes apresentadas fotograficamente constituíam-se em discretas vacuolizações focais da camada odontoblástica.

Em 1974, no New York State Dentistry Journal, os endodontistas Spector, Rothenhaus e Herman ${ }^{88}$, do Queen's Hospital Center, apresentaram dois casos de necrose pulpar aque atribuíram como causa o movimento ortodôntico. Uma menina de 16 anos no segundo pré-molar inferior; o outro, uma mulher de 39 anos que há 27 anos foi submetida a tratamento ortodôntico e agora se apresentou com necrose pulpar em seu canino superior. Como não havia história de trauma anterior relatada pelos pacientes, atribuíram aos casos uma causa ortodôntica, fundamentando-se em opiniões emitidas por autores em livros textos, sem qualquer preocupação em resgatar dados experimentais ou evidências metodológicas sobre o assunto.

Em 200 casos, Stanley et al..$^{92}$, em 1978, estudaram polpas de dentes com infarto anêmico, sendo que em 150 casos havia história de traumatismos com tempos variáveis de 20 horas a 10 anos. Em dois casos, havia história de tratamento ortodôntico. O traumatismo mais freqüente foi o acidente automobilístico descrito em 31 das 121 histórias. As alterações de cor ocorrerem em apenas 79 dentes e alterações periapicais em 69 casos. Apenas um caso ocorreu em pré-molar, os demais eram dentes anteriores. 
Para Stanley et al. ${ }^{92}, 1978$, nas polpas extirpadas com material granular avermelhadoalaranjado, com núcleos picnóticos, representavam alterações degenerativas precoces de infarto anêmico. A oclusão dos vasos sangüíneos decorrentes do trauma pode levar à isquemia, rompimento das paredes capilares, escape de eritrócitos e conversão dos pigmentos de hemoglobina em debris granulares que permanecem na polpa.

Em trabalho de revisão de 1979, Freire e Tancredo ${ }^{28}$ descreveram muitos efeitos com base em opiniões resgatadas de livros textos ou de artigos não específicos sobre o assunto e reconheceram, textualmente, que: "é evidente que muitos dos temidos danos que supostamente são causados por aparelhos ortodônticos são mais teóricos do que reais." Mesmo assim, apesar da falta de fundamentação metodológica, após discutirem a literatura, os autores apresentaram quatro casos clínicos, procurando relacionar alterações pulpares com tratamento ortodôntico que deveriam ser reavaliados em sua história, diagnóstico e etiopatogenia, antes de conclusões tão taxativas como foram emitidas. Alguns casos de mineralização generalizada da polpa devem ser atribuídos à metamorfose cálcica da polpa, uma situação clínica reconhecidamente de origem traumática e não atribuída ao movimento ortodôntico.

"In vivo", em 21 incisivos de ratos movimentados experimentalmente, Guevara e MacCluggage $^{29}$, em 1980, observaram microscopicamente uma diminuição inicial do fluxo sangüíneo pulpar. Concluíram que é evidente que o movimento ortodôntico altera o fluxo sangüíneo da polpa. Entretanto, os seus resultados devem ser avaliados à luz da limitação do experimento, por ter sido realizado em um dente com morfologia muito diferente da humana, por sua curvatura e pela sua natureza de odontogênese contínua, com ápice e fisiologia completamente distintas dos dentes humanos e de outros animais ou mesmo do próprio rato. Em molares de ratos, essa diferença não existe, pois, sua forma e completa formação se assemelham às do homem.

Ainda em 1980, Hamersky et al. ${ }^{31}$ estudaram o efeito de forças ortodônticas sobre o metabolismo respiratório de polpas humanas em pré-molares, a partir da mar- 
cação com dióxido de carbono radioativo. Os dentes analisados foram escolhidos ao acaso para constituírem o grupo controle e experimental e extraídos três dias após a aplicação da força. A respiração pulpar diminuiu 27,4\% no grupo de polpas de dentes tratados com movimentos ortodônticos, utilizando-se forças de curta duração. Essas alterações bioquímicas, para os autores, podem ser mais significantes com o aumento da idade do paciente a ser submetido a essas forças ortodônticas. Resultados semelhantes foram obtidos por Unsterseher ${ }^{102}$, em 1987, com a mesma metodologia em dentes humanos submetidos a forças ortodônticas, sendo que o índice respiratório medido ,após sete dias de descanso, sem aplicação da força, foi 32,2\% menor. Entretanto, os autores sugeriram que outros trabalhos deveriam ser realizados para confirmar os resultados, pois, não havia como comparar grupos imediatamente antes e depois do descanso.

A avaliação bioquímica do índice respiratório de polpas murinas de dentes submetidos à movimentação ortodôntica em 56 polpas de incisivos centrais de 26 animais, separados por elásticos, foi realizada por Labart et al. ${ }^{46}$, em 1980 e indicou que houve um aumento de 1,2 vezes, considerado estatisticamente significante. Os autores acreditavam ser o método bioquímico mais sensível para avaliar os efeitos pulpares do movimento ortodôntico, mas o trabalho apresentou uma séria limitação metodológica para ser extrapolado para uma situação clínica em humanos: o movimento dentário experimental foi realizado em incisivos centrais, um dente com rizogênese contínua e morfologia incomparável à dos humanos.

A preocupação com os efeitos do movimento ortodôntico sobre os nervos pulpares levou Bunner e Johnsen ${ }^{10}$, em 1982, a analisarem, em microscopia eletrônica de transmissão, essas estruturas em oito pré-molares humanos de quatro pessoas. Foram estabelecidos quatro pares de pré-molares: ápices abertos e submetidos a movimentos breves, ápices completos e movimentos prolongados, ápices fechados e movimentos breves, ápices fechados e movimentos prolongados. Os dentes foram comparados com 49 dentes normais considerados como grupo controle. Os autores não detectaram qual- 
quer diferença quer nas fibras mielinizadas quer nas não mielinizadas. Algumas figuras mielínicas apresentaram-se alteradas nos movimentos de curto período (7 a 10 dias), mas, nem mesmo essas, foram encontradas nos dentes submetidos a movimentos de longa duração (171 a 225 dias).

Para Delivanis e Sauer ${ }^{19}$ (1982), os clínicos deveriam considerar a possibilidade de dentes tratados ortodonticamente apresentarem calcificações pulpares. Comparando 46 pacientes ortodonticamente tratados com um grupo controle com características semelhantes quanto à idade, esses autores encontraram três dentes com calcificação do canal, sendo dois em mesmo paciente e todos incisivos superiores. Apesar de relatar não terem sido estatisticamente significantes seus resultados, afirmaram que essa pode ser uma conseqüência do tratamento ortodôntico. Apesar de um evidente diagnóstico de metamorfose cálcica da polpa dentária, cuja etiopatogenia é traumática, em nenhum ponto da discussão há referência sobre essa possibilidade.

Em radiografias obtidas antes e imediatamente depois do tratamento ortodôntico, Matos $^{54}$, em 1983, encontrou 37 pacientes com calcificações pulpares em 320 examinados, ou seja, 11,6\%. O autor concluiu que o tratamento ortodôntico pode ser responsável por calcificações pulpares acentuadas na cavidade pulpar de dentes isolados. Essas calcificações ocorreriam independentes da idade e do sexo do paciente, além do tempo de tratamento ativo.

Em estudo microscópico sobre as reações teciduais sob forças extrusivas e intrusivas em dentes de três macacos adultos, Melsen ${ }^{57}$, em 1986, contrastou os resultados de trabalhos que indicavam alterações pulpares significantes diante de forças ortodônticas, reconhecendo apenas que as reações pulpares são de menor extensão e significado. Atribuiu os efeitos dos trabalhos anteriores a forças excessivas empregadas (60 a 275g), como no trabalho de Stenvik e Mjör ${ }^{96}$ (1970), enquanto que no seu trabalho foram empregadas $10 \mathrm{~g}$.

A partir de técnicas radiorespirométricas que marcam o dióxido de carbono e 
determinam o consumo de oxigênio pelos tecidos, em 1987, Unsterseher et al. ${ }^{102}$ detectaram em 40 pré-molares humanos, movimentados com elásticos, que o índice respiratório reduzia em 33,2\% após 72 horas da aplicação da força. Demonstraram ainda que havia uma correlação dessa redução com o fechamento apical do dente envolvido, mas, não havia qualquer relação com a idade do paciente.

A dor induzida na movimentação ortodôntica foi o motivo para Walker et al. ${ }^{110}$, em 1987, mensurarem a presença da encefalina metionina, do grupo das encefalinas que representam um dos grupos de proteínas que modulam a dor juntamente com a norepinefrina, epinefrina, dopamina, serotonina, glicina, glutamato, histamina e substância P. As enfelinas, provavelmente, inibem a dor reduzindo a secreção da substância $P$, um neuropeptídeo que aumenta a sensibilidade dos neurônios em informações nociceptivas. Em pré-molares humanos extraídos, foi mensurada a presença da encefalina metionina divididos em grupos controle e movimentado. A partir da cromatografia, radioimunoensaios e espectofotometria observaram que, nas polpas dos dentes movimentados, havia menor índice de encefalina metionina do que nas polpas de dentes do grupo controle e que isso era inversamente proporcional à intensidade da força aplicada.

Após induzir a movimentação dos primeiros molares superiores do rato, Kvinnsland et al. ${ }^{44}$ (1989) deixaram transcorrer cinco dias e aplicaram microesferas fluorescentes injetadas na circulação via catéter no ventrículo esquerdo. Após cinco dias de aplicação de forças contínuas mesiais, havia alteração no fluxo sangüíneo pulpar nos molares de ratos, pois, os autores encontraram maior número de microesferas nos tecidos pulpares e periodontais do que no grupo experimental controle. Entretanto, esse trabalho também revelou diferenças nos resultados obtidos nos segundos e terceiros molares, que não foram movimentados.

A ocorrência de vasos dilatados e congestos associados à edema pulpar em estudo microscópico realizado em 18 pré-molares humanos extruídos ortodonticamente foi relatada, em 1991, por Mostafa et al. ${ }^{62}$, após uma, duas e quatro semanas. Nesses 
períodos de observação, os autores descreveram edema, vacuolização do tecido pulpar, vasos congestos e severa degeneração odontoblástica, além de fibrose; a cada descrição, os autores indicavam figuras com notáveis artefatos de técnica e fixação, o que, infelizmente, impedeiu conclusões dessa natureza.

Diferenças não foram observadas em polpas de adolescentes submetidos à movimentação ortodôntica em relação ao grupo controle no estudo de Popp et al. ${ }^{77}$, em 1992. Foram analisados 100 adolescentes tratados ortodonticamente e 76 não tratados. A metodologia baseou-se em radiografias periapicais. Eventualmente, encontraram alterações iguais às encontradas em traumatismos. Para os autores, o tratamento ortodôntico na adolescência não representa aumento do risco de danos à polpa ou mesmo ao periodonto. Uma explicação pode estar nos períodos de descanso entre procedimentos. Outra possibilidade para essa ausência de alterações pulpares, durante a movimentação ortodôntica, pode estar na magnitude da força utilizada, sob condições clínicas, que não excederia os limites fisiológicos de tolerância do tecido pulpar. Em sua discussão, os autores afirmaram: baseados em nossos resultados, o tratamento ortodôntico não está relacionado ao desenvolvimento de nódulos pulpares.

A correlação entre o movimento ortodôntico e o estado pulpar foi o principal objetivo do estudo de Nixon et al. ${ }^{63}$, em 1993. Quatro grupos de ratos Sprague-Dawley foram estudados com magnitudes diferentes de forças aplicadas: controle, 20, $40 \mathrm{e}$ $60 \mathrm{~g}$ de força inicial designada de inclinação mesial nos primeiros molares superiores. Foram forças consideradas de baixa, média e alta magnitude do ponto de vista do movimento obtido e microscopicamente. Seis ratos foram sacrificados a cada um dos períodos experimentais: 1, 3, 5, 7, 10 e 14 dias. Em seus resultados, os autores afirmaram que não houve diferença significante entre a percentagem de vasos no tecido pulpar em qualquer tempo e magnitude de força aplicada, sem qualquer efeito específico para locais determinados da polpa. Entretanto, no resumo, consideraram que os achados indicavam um aumento representativo no número de capilares relacionados ao tempo e 
magnitude de força. Ressaltaram que os efeitos principais foram uma hiperemia inicial após a aplicação da força, mas não relacionada à magnitude da força. Também observaram um aumento força-dependente na pré-dentina. Na discussão des resultados, os autores não levaram em consideração o conceito de hiperemia: um aumento de volume sangüíneo para uma determinada área corporal que, microscopicamente, não é preciso avaliar-se em cortes teciduais, nos quais pode se observar apenas congestão vascular, que não necessariamente representa hiperemia.

A análise de 26 polpas de dentes submetidos à movimentação ortodôntica foi realizada em microscopia óptica por Oda ${ }^{65}$, em 1993. Foram obtidas de pacientes entre 11 a 23, anos de ambos os sexo. Não houve a concepção de um grupo controle no design experimental. As polpas estavam dentro da normalidade, com exceção de 13 polpas com estruturas mineralizadas de diversos tamanhos e formas, talvez em função de maturação em vários estádios. Os nódulos pulpares foram interpretados como reações defensivas da polpa, provavelmente, provenientes de estímulos mecânicos. Nesse trabalho, infelizmente, a interpretação dos resultados e sua extrapolação ficaram dificultadas pela ausência de um grupo controle.

Em 1994, a proposta do estudo de Woloshyn et al. ${ }^{111}$ foi avaliar as diferenças entre o estado pulpar e periodontal, o comprimento da raiz e o alinhamento entre incisivos laterais, caninos e pré-molares contralaterais em pacientes tratados com impacção unilateral do canino superior. Foram examinados clínica e radiograficamente 32 pacientes com idade média de 22 anos e 11 meses, por um período médio de observação de 3 anos e 7 meses. As cristas ósseas e o comprimento radicular foram diminuídos. A obliteração pulpar foi detectada em seis caninos previamente impactados (21\%) e a necrose pulpar em apenas um canino impactado. As polpas dos demais dentes se apresentavam normais, radiograficamente. Em oito caninos, previamente impactados, o teste elétrico foi negativo.

A fluxometria por Laser-Doppler foi utilizada por McDonald e Pitt Ford ${ }^{56}$, em 
1994, para verificarem que o fluxo sangüíneo pulpar humano diminuía de forma breve, aproximadamente por 32 minutos, durante a aplicação de forças de inclinação leve com 50g aplicadas em caninos superiores com aparelhos removíveis. Após 24 e 48 horas, o fluxo aumentava, mas voltava ao normal depois de 72 horas de movimentação. Para os autores, essa situação foi caracterizada como hiperemia reativa.

Os nódulos pulpares, geralmente, representam depósitos minerais, tipo calcificação ou mineralização distrófica, em: 1. áreas hialinizadas da matriz extracelular da polpa dentária associadas a maior grau de fibrosamento; 2 . áreas focais de necrose por coagulação e asséptica; 3 . áreas hialinas nas paredes vasculares e neurais da polpa ${ }^{14}$. Os nódulos pulpares podem fazer parte do envelhecimento pulpar, mas, geralmente, ocorrem precocemente e em maior número em função de inúmeros fatores que atuam sobre a polpa, promovendo redução da sua celularidade e aumento da densidade no fibrosamento, decorrente do aparecimento das áreas de hialinização. Entre os fatores associados a esse processo, têm-se: desgastes dentários, cárie dentária, restaurações, traumatismos, procedimentos operatórios etc. Do ponto de vista epidemiológico, é impossível afirmar quais os fatores que, ao longo da vida, em uma determinada população, atuaram ou não sobre os dentes para promover maior ou menor freqüência de nódulos pulpares. Além da forma localizada de mineralização pulpar, tem-se ainda a forma generalizada, na qual há evidências radiográficas de obliteração da câmara pulpar e ou dos canais radiculares e pode ocorrer em duas situações, por dois mecanismos diferentes. 1. A mineralização difusa da polpa pelo mecanismo da calcificação metastática está relacionada a estados sistêmicos caracterizados por elevadíssimo nível plasmático de cálcio. Esse nível sangüíneo está a tal ponto elevado que promove a deposição de sais minerais na matriz extracelular de tecidos conjuntivos normais, entre os quais, a polpa ${ }^{14}$. 2. Em dentes traumatizados, as células da polpa, de forma generalizada e desordenada, podem sofrer metaplasia odontoblástica e depositar, aleatoriamente, matriz de tecido mineralizado osteodentinóide, recebendo também a denominação de metamorfose cálcica da polpa. 
Em 1995, Pereira Jr. e Varoli ${ }^{75}$ selecionaram um grupo de 29 pacientes que foram tratados, e um grupo controle, também de 29 pacientes, sem tratamento ortodôntico. Os dois grupos foram comparados radiográfica e longitudinalmente. Vinte nove pacientes foram avaliados imediatamente antes do tratamento ortodôntico, logo após o tratamento e, em média 15 anos após o término do tratamento ortodôntico. Em 28, ou 96\%, dos pacientes tratados ortodonticamente havia calcificações pulpares, enquanto que no grupo controle, 18 pacientes, ou $62 \%$, apresentaram tais estruturas em suas polpas. No grupo tratado, 179 de 256 dentes analisados revelaram calcificações pulpares ou $67 \%$, enquanto que 51 em 249 dentes de pacientes não tratados, ou grupo controle, apresentaram-nas ou 22\%. Na discussão de seu trabalho, Pereira Jr. afirmou que os fatores ortodônticos relacionados seriam: quantidade de força empregada nas ativações, quantidade de movimentação de cada dente, direção, ritmo de movimento e tempo de tratamento. Esses dados obtidos levaram-no a recomendar intervalos maiores entre as ativações dos aparelhos ortodônticos e controle radiográfico periódico dos dentes envolvidos para evitar calcificações pulpares.

Os efeitos pulpares da ação de forças ortodônticas de intrusão foram estudados microscopicamente em dentes humanos por Mendonça et al. ${ }^{58}$, em 1996. Foram utilizados 30 pré-molares de pessoas com idade entre 13 e 18 anos de ambos os sexo, divididos igualmente em grupo controle e experimental. A força intrusiva foi exercida por 45 dias. Além de descrever reabsorções apicais, os autores descreveram que 77\% (provavelmente 11,55 dentes) da amostra, sobre a qual se aplicou força intrusiva, apresentou polpa completamente normal, não sendo possível detectar diferenças morfológicas. Nos dentes com alterações pulpares detectadas (33\% da casuística, provavelmente 4,95 dentes), observaram um espécime com infiltrado inflamatório crônico e calcificações nos demais, notadamente na porção radicular da polpa. Para os autores, as observações realizadas não permitiram fazer considerações a respeito das implicações clínicas e sugeriram novos estudos. Nesse trabalho, provavelmente, houve um erro de cálculo ou gráfico, pois, deve ser $23 \%$ da casuística com alterações pulpares, ou 3,45 dentes, e não 33\% . 
As pesquisas de Butcher e Taylor ${ }^{11}$, em 1952, e Stenvik e Mjör ${ }^{96}$, em 1970, especulando que o fluxo sangüíneo pulpar pudesse ser alterado durante o tratamento ortodôntico; e em, 1994, o relato de McDonald e Pitt Ford ${ }^{56}$ induziram Barwick e Ransay5, em 1996, a utilizarem a fluxometria por Laser-Doppler para detectar alterações no fluxo sangüíneo pulpar após aplicação de força intrusiva, atuando por quatro minutos em incisivos superiores humanos. Oito pessoas submeteram-se à aplicação da força intrusiva nos seus incisivos centrais superiores por um sistema de alavanca. Um casquete de cromo-cobalto foi confeccionado, copiando fielmente a coroa do incisivo de cada uma das oito pessoas e utilizado como extremidade do sistema de alavanca para aplicação da força intrusiva. Cada paciente participou de cinco sessões de testes. Em cada sessão, os testes duravam quatro minutos com aplicação de força e mensuração do fluxo sangüíneo e mais 12 minutos para mensurações sem a ação da força intrusiva. Os pesos colocados na extremidade das alavancas variaram de $0,5,50,500 \mathrm{gm}$ com forças intrusivas geradas de 75 a 4498gm. Na quinta sessão, após os quatro minutos de aplicação da força, foi aplicado no local anestésico com vasoconstritor para determinar a habilidade de detecção no sistema do fluxo sangüíneo por parte do aparelho de fluxometria por Laser-Doppler, pois, não se detectavam alterações nos testes realizados. Quando da aplicação do anestésico, após os quatro minutos, detectaram uma acentuada queda no fluxo pelos 12 minutos seguintes, demonstrando eficiência do método. A magnitude da força não gerou diferença significante entre as cinco sessões e esse resultado sugere que o fluxo sangüíneo pulpar não é alterado pela aplicação de forças intrusivas em curtos períodos.

Para colaborar com os estudos sobre o efeito do movimento ortodôntico sobre os tecidos pulpares, Derringer et al..$^{20}$, em 1996, avaliaram a secreção de fatores angiogênicos. Foram coletadas 15 polpas de pré-molares humanos, movimentados ortodonticamente, e compararam com outras 15 de dentes não movimentados como controle, dos mesmos pacientes. As polpas eram coletadas, seccionadas em cortes de $1 \mathrm{~mm}$, embebidas em colágeno e cultivadas por quatro semanas em meio apropriado. As cul- 
turas eram examinadas diariamente para verificar a formação de novos vasos, o que foi verificado iniciar-se aos cinco dias. Aos cinco e dez dias, a diferença de formação de microvasos no grupo de polpas derivadas dos dentes movimentados era grande em relação ao grupo controle e foram confirmados na microscopia eletrônica. A conclusão extraída pelos autores foi que os fatores angiogênicos aumentam na polpa de dentes movimentados ortodonticamente.

Como estudo piloto, Hall e Freer ${ }^{30}$, em 1998, analisaram as respostas dos testes pulpares elétricos ao calor e ao frio, em cinco pacientes com dentes movimentados ortodonticamente e as compararam na hora de instalação dos aparelhos e um e dois meses depois de aplicação de forças com testes anteriores nos mesmos dentes. Compararam ainda as respostas com outros dois pacientes que não tiveram dentes movimentados ortodonticamente. Foram avaliados os seis dentes anteriores superiores de cada paciente. Um mês depois, houve perda ao estímulo elétrico, embora, ao teste térmico houvesse resposta continuada. Aos dois meses, a perda de resposta ao teste elétrico continuou. $\mathrm{Na}$ conclusão, os autores recomendaram cuidados na interpretação de testes elétricos em dentes movimentados ortodonticamente e sugeriram que os testes térmicos são mais apropriados para essa situação.

Após dois anos de trabalho inicial, Derringer et al. ${ }^{21}$, em 1998, avaliaram a secreção de fatores angiogênicos em 14 polpas de pré-molares humanos movimentados ortodonticamente por duas semanas e compararam com outras 14 de dentes não movimentados como controle, dos mesmos pacientes. As polpas foram igualmente coletadas como no trabalho anterior, como também se coletaram microamostras de aorta. As culturas eram examinadas diariamente para verificar a formação de novos vasos, o que foi verificado iniciar-se aos cinco dias. Aos cinco, dez e quatorze dias, a diferença de formação de microvasos no grupo de polpas derivadas dos dentes movimentados era grande em relação grupo controle e foram confirmados na microscopia eletrônica e imunoistoquimicamente pelo uso do antígeno relacionado ao fator VIII das células endoteliais, o mesmo ocorrendo nas amostras de tecidos coletados da aorta. A conclusão 
extraída pelos autores foi que os fatores angiogênicos aumentam na polpa de dentes movimentados ortodonticamente e que esses fatores angiogênicos são difusíveis para outras partes do corpo.

Os efeitos do tratamento ortodôndico na polpa dentária foi avaliado por Wong et al. ${ }^{112}$, em 1999, em 12 pacientes, comparando-se microscopicamente pré-molares humanos movimentados de um lado com os contra-laterais. A fixação dos espécimes foi detalhadamente cuidada, incluindo-se cortes no terço médio do dente logo após sua extração. Os dentes foram movimentados por aplicação de forças na hora da instalação com reativação por mais duas semanas. Os aparelhos eram removíveis. Os resultados revelaram que não houve grande diferença entre os grupos movimentados e não movimentados, destacando-se apenas maior vasodilatação pulpar nos dentes ortodonticamente movimentados. Ao discutirem, os autores compararam seus resultados com os de Melsen ${ }^{57}$ que, em 1986, em macacos adultos, não encontraram efeitos pulpares, atribuindo-os ao uso de diferentes forças: nos humanos $170 \mathrm{~g}$ e nos primatas $10 \mathrm{~g}$.

Uma ampla revisão sobre a inter-relação endodontia e ortodontia foi apresentada em 1999 por Hamilton e Gutmann ${ }^{32}$, a qual reserva grande espaço para os efeitos pulpares do movimento ortodôntico. Apesar de utilizar como referência uma parte de artigos sobre o assunto, não relevam suas limitações metodológicas e, ao mesmo tempo, utilizam muitas citações de livros textos, sem explicarem como chegaram a tais conclusões sobre os efeitos pulpares do tratamento ortodôntico e, quando citam uma única vez a possibilidade de uma eventual necrose pulpar, utilizam o trabalho de Delivanis e Sauer ${ }^{19}$, de 1982, no qual exploram casos de calcificações pulpares em apenas três dentes de dois pacientes submetidos a movimento ortodôntico. Os autores, nesse tópico, promoveram uma ampla discussão, com base em uma hipótese levantada na literatura por Bender et al. ${ }^{7}$ (1997) sobre o papel de neuropeptídeos das polpas de dentes movimentados na iniciação e manutenção das reabsorções apicais. Em suas conclusões, afirmaram que as agressões prévias à polpa dentária são muito importan- 
tes na etiopatogenia dos problemas endodônticos diagnosticados durante o tratamento ortodôntico tais como o trauma, cáries e restaurações. Em todo o trabalho, citam como possíveis efeitos as alterações no fluxo sangüíneo, na vasodilatação e no nível de neuromediadores; não há menção a pulpites e reabsorção interna.

As reações pulpares de dentes de primatas, submetidos à disjunção palatina, foram avaliadas por Prietsch et al. $^{79}$, em 1999 , em trabalho publicado na revista Ortodontia Gaúcha. Concluíram, com base em observações dos dentes dos três animais, que os efeitos pulpares eram muito significantes. Infelizmente, devemos destacar que suas conclusões tiveram por base interpretações equivocadas, microscopicamente realizadas pela identificação de infiltrado inflamatório linfoplasmocitário, trombos, tecido de granulação e abscesso pulpares. Esses equívocos podem ser constatados na análise das fotomicrografias apresentadas no trabalho: 1. o infiltrado corresponde à celularidade normal de uma polpa jovem; 2. a vacuolização dos odontoblastos apresentada corresponde a limitações de fixação pulpar; e 3) o abscesso pulpar corresponde a um espaço anteriormente ocupado por dentina removida durante a microtomia e que permaneceu circunscrito pela camada odontoblástica, que foi interpretada como acúmulo periférico de polimorfonucleares neutrófilos, o que caracterizaria uma inflamação aguda purulenta.

$\mathrm{Na}$ expansão rápida do palato, a força supostamente exercida sobre os pré-molares é muito maior do que a exercida pelos clássicos movimentos ortodônticos; segundo Zimring and Isaacson ${ }^{114}$ (1965), na expansão rápida do palato, as forças variam de 7,54 a 15,8 kg. Com o objetivo de avaliar as reações pulpares durante a expansão rápida do palato, Kayhan et al..$^{40}$, em 2000, estudaram microscopicamente a polpa de pré-molares superiores e utilizaram ainda métodos histomorfométricos. Por indicação ortodôntica, 34 pré-molares superiores seriam extraídos. Em 23 deles, isso foi providenciado após realizar-se a expansão rápida do palato; os outros 11 pré-molares foram extraídos sem se submeterem a qualquer força ortodôntica. Os resultados revelaram que a área 
ocupada pelos vasos e seus diâmetros mostravam diferença significante entre os grupos, especialmente, entre o grupo controle e o subgrupo de três meses. Na conclusão, os autores atribuiram essas modificações a uma resposta adaptativa da polpa às forças ortodônticas, o mesmo ocorrendo com alterações fibróticas encontradas. O aumento de elementos fibróticos foi atribuído à hipótese de que haveria um envelhecimento acelerado dessas polpas; segundo os autores, isso indicava que, após três meses, o movimento ortopédico não mais atuava, iniciando-se um movimento dentário de natureza ortodôntico. Nesse trabalho, as fotomicrografias revelaram números artefatos de técnica, especialmente, relacionados à fixação da polpa dentária.

Afirmando que a compreensão dos efeitos microscópicos desencadeados pela expansão rápida da maxila sobre os dentes de ancoragem compõe a seguridade biológica de um procedimento biomecânico já conhecido e considerando alguns relatos sugerindo alterações no complexo dentinopulpar, após esse procedimento, Valladares Neto $^{103}$, em sua dissertação de mestrado, propôs-se a avaliar a resposta imediata à expansão e a ocorrida após 120 dias de contenção. Outra variável estudada foi o protocolo de ativação: duas ou quatro vezes ao dia. Para 12 adolescentes de 12 a 16,5 anos, selecionados aleatoriamente, foram estabelecidos quatro grupos experimentais; outros três adolescentes constituíram o grupo controle. As análises microscópicas descritiva e morfométrica revelaram que a expansão rápida da maxila é um procedimento biologicamente seguro para o complexo dentinopulpar e para a superfície radicular, não obstante, tenham ocorrido reabsorções radiculares externas. Não ocorreram manifestações no complexo dentinopulpar quer seja na porção coronária quer na parte radicular.

Ao relatarem que Barwick e Ransay ${ }^{5}$, em 1996, utilizaram a fluxometria por Laser-Doppler para detectar alterações no fluxo sangüíneo pulpar, Ikawa et al. ${ }^{38}$, em 2001, apontaram graves erros metodológicos e criticaram uma casuística constituída por apenas oito pessoas. Não consideraram a ausência de alterações no fluxo sangüíneo relatada como válidas e propuseram avaliá-las em 17 pessoas de forma mais cri- 
teriosa, utilizando-se também da fluxometria por Laser-Doppler. Por sua vez, Ikawa et al. ${ }^{38}$ (2001) demonstraram que forças de 0.5 , de 1 e $5 \mathrm{~N}$ por 20 segundos promoveram reduções no fluxo sangüíneo pulpar quando aplicadas nas margens de incisivos centrais superiores esquerdos de 17 pessoas, quando se realizava a fluxometria de LaserDopller, simultaneamente à ação da força.

As respostas pulpares em dentes submetidos a forças ortodônticas extrusivas foram avaliadas por Subay et al..$^{99}$, em 2001, a partir da microscopia óptica de dois grupos de dentes: 20 extruídos por aparelhos fixos e 20 por meio de elásticos. Os períodos de observação foram 10 e 40 dias após a aplicação da força. Em nenhum dente, houve detecção de processo inflamatório e ou de formação de dentina reacional. Em cinco dentes do grupo extruídos com elásticos e dois dentes do grupo com aparelhos fixos, mostraram númerosos nódulos pulpares (17,5\% de todos os casos). Em sete casos com o uso de aparelhos fixos e em dois dentes com o uso de elásticos, notou-se a aspiração de odontoblastos nos túbulos dentinários $(22,5 \%)$. Esses dados foram revelados no trabalho por lindas fotomicrografias. Os resultados levaram os autores a concluírem que forças extrusivas não induzem alterações patológicas nos tecidos pulpares humanos.

Em 2002, Sano et al. ${ }^{83}$ mensuraram, por meio do Laser Doppler, o fluxo sangüíneo da polpa de 13 incisivos centrais inferiores, submetidos a forças intrusivas contínuas, em 13 pessoas, sendo oito experimentais e cinco como parte de grupo controle. O fluxo sangüíneo pulpar foi medido antes da instalação do aparelho, durante e após a aplicação da força. Os resultados mostraram que o fluxo sangüíneo diminuiu durante a aplicação da força e retornava ao normal quando a mesma era removida.

A enzima aspartato aminotransferase representa uma enzima cujo nível no meio extracelular aumenta quando células estão entrando em necrose; também isso ocorre em condições fisiológicas caracterizadas pela aceleração do turnover tecidual. Perinetti et al. ${ }^{76}$, em 2004, mensuraram a quantidade da aspartato aminotransferase em polpas de dentes movimentados ortodonticamente. Eram 17 pré-molares humanos e 
foram utilizados aparelhos fixos; os dentes contralaterais foram utilizados como grupo controle. Após uma semana de aplicação de força, as polpas foram coletadas para os testes bioquímicos. $\mathrm{O}$ aumento da enzima foi significantemente elevado nas polpas de dentes movimentados quando comparado aos níveis do grupo controle. Os autores concluíram que o movimento ortodôntico aumenta o metabolismo pulpar nas suas fases iniciais, sem correlação com a idade do paciente.

A movimentação ortodôntica e seus efeitos pulpares foram analisados em 91 terceiros molares imaturos e transplantados por Bauss et al. ${ }^{6}$ em 2004. Alguns dos dentes transplantados ficaram rotacionados ou infra-ocluídos em sua posição em função de atrofia do processo alveolar receptor ou da morfologia radicular irregular. Após 3 a 6 meses, 28 transplantes foram girados e 21 extruídos. Os outros 42 dentes transplantados não foram movimentados e serviram como grupo controle. Todos os transplantes foram seguidos clínica e radiograficamente, em média, por quatro anos. Nos dentes extruídos, não houve qualquer diferença entre o grupo movimentado ortodonticamente e o grupo controle. Nos dentes rotacionados, houve uma correlação significante entre necrose pulpar e movimentos de rotação nos transplantes de dentes multirradiculados. Para os autores, os resultados revelam que pequenos movimentos laterais e extrusão em molares transplantados, mesmo rotações em molares monorradiculados, não alteram significantemente a polpa e o periodonto e não representam o menor risco para a sobrevida dos transplantes. Ao contrário, em molares multirradiculados, a rotação pode levar a severos danos no suprimento sangüíneo e neural da polpa.

Em 2005, Villa et al. ${ }^{108}$ procuraram analisar clínica e microscopicamente, em pré-molares humanos, os efeitos pulpares e periodontais da intrusão dentária ortodôntica bem como os efeitos de uma droga antiinflamatória não esteróide, o nabumetone, na redução da possível inflamação induzida e conseqüente dor. Foram selecionados 25 pacientes, 13 mulheres e 12 homens com idade entre 12 e 25 anos. Quinze pré-molares fizeram parte do grupo experimental e 16, do grupo controle. Uma barra 
palatina serviu de ancoragem para que um aparelho idealizado fosse aplicado sobre os pré-molares para gerar forças intrusivas. A força intrusiva atuou por oito semanas em ambos os grupos com reativação na quarta semana; no grupo controle, os pacientes receberam placebo.

De acordo com resultados, Villa et al. ${ }^{108}$ assim descreveram: $O$ terço coronal $d a$ camada odontoblástica dos dentes submetidos a forças intrusivas estava alterado. No terço apical estava normal. A quantidade de dentina foi analisada, mas não revelou diferença estatisticamente significante entre os grupos controle e experimental. Houve diferenças quanto à espessura da pré-dentina entre os dois grupos, mas no terço médio e apical eram normais e iguais. A vacuolização odontoblástica estava presente como leve no terço coronário e ausente no terço médio e apical em ambos os grupos. Na verdade, essa descrição revela que houve problemas na fixação das peças, pois, não foram seccionadas assim que os dentes foram extraídos e a formalina utilizada apenas penetrou imediatamente no terço apical. No terço médio e coronário, o fixador demorou a chegar e alterações degenerativas se instalaram nos odontoblastos e demais células da polpa, promovendo acúmulo de água com vacuolização e rompimento celular. Todas essas alterações, decorrentes da polpa, podem ser visualizadas nas fotomicrografias apresentadas no trabalho, o que inviabiliza considerar-lo como parâmetro comparativo. Nas conclusões do trabalho, Villa et al. ${ }^{108}$ afirmaram que o antiinflamatório utilizado como analgésico para dar conforto ao paciente, após a ativação do aparelho ortodôntico, não prejudica a movimentação dentária.

Em síntese, podemos afirmar que a literatura pertinente é muito variada nos seus modelos e critérios de análise bem como nos resultados e nas conclusões apresentadas. 


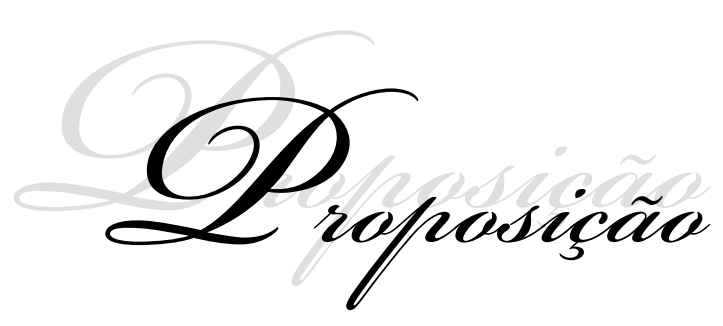




\section{Proposição}

A partir dos questionamentos sobre os efeitos pulpares da movimentação ortodôntica e da busca de dados em uma análise criteriosa da literatura pertinente sobre o assunto, em cortes teciduais de molares de ratos, propusemo-nos a:

a) analisar microscopicamente o complexo dentinopulpar de molar de rato submetido à movimentação dentária, induzida em diferentes períodos tal como a ocorrência de hialinização, fibrosamento, calcificações, pulpites e necrose pulpar;

b) comparar os dados obtidos com os da literatura para fundamentar biologicamente os efeitos pulpares da movimentação dentária induzida na clínica odontológica. 
Caterial métodos 


\section{Material e métodos}

\subsection{Amostragem}

A amostra conjunta do experimento abrangeu 49 ratos da linhagem Wistar (Rattus norvegicus, albinos), com 120 dias de vida, provenientes do Biotério Central da Faculdade de Odontologia de Bauru, da Universidade de São Paulo. Os períodos de observação foram 1, 2, 3, 4, 5, 6 e 7 dias de movimentação dentária induzida nos primeiros molares superiores (Figura 2). Em dez animais, não se movimentaram os dentes para servirem como grupo controle. A cada período, procuramos analisar três animais, mas nos 3, 5 e 7 dias, o número de animais foi 9, pois, correspondem aos melhores períodos de observação da movimentação dentária induzida. Como pretendíamos nos assegurar, observamos os períodos intermediários aos estabelecidos, e optamos por analisar três animais aos 1, 2, 4 e 6 dias após a movimentação.

A amostra foi, em parte (17 animais), a mesma utilizada como grupo controle na tese de doutoramento de Martinz-Ortiz ${ }^{53}$, em 2004, cujo objetivo principal foi investigar a influência do bisfosfonato alendronato nas reabsorções radiculares relacionadas à movimentação dentária induzida em diferentes períodos experimentais, ou seja, 3, 5 e 7 dias, quando, então, foram imolados.

“Durante todo o período experimental, os animais permaneceram acondicionados em gaiolas, contendo cada uma, de 3 a 6 animais. Manteve-se o ambiente com iluminação natural e temperatura ambiente, apresentando-se constantemente limpo e arejado. A alimentação dos animais constituiu-se de ração de nome comercial Labina, da marca Purina fornecida ad libitum, assim como o provimento de água. Mantiveram-se os animais durante o experimento no Biotério Central da Faculdade de Odontologia de Bauru até os 90 dias e posteriormente no biotério da Disciplina de Patologia Bucal da FOB/USP, durante a fase de instalação dos aparelhos até a data 
da morte dos animais. Durante o período em que os animais permaneceram com o aparelho em posição, a alimentação constituiu-se da mesma ração, triturada em um pequeno pilão e depositada em um recipiente de vidro em cada gaiola, da mesma forma sem restrição quanto à quantidade. A trituração da ração objetivou reduzir o esforço durante a mastigação, evitando a danificação e a remoção dos dispositivos ortodônticos pelos animais, durante a alimentação. ${ }^{, 53}$.

Os 49 animais foram distribuídos de acordo com o período de observação experimental. Dessa forma, caracterizaram um grupo controle negativo sem movimentação dentária induzida e sete subgrupos de 1, 2, 3, 4, 5, 6 e 7 dias de movimento dentário induzido, como revela a tabela 1 .

TABELA 1 - Distribuição dos animais de acordo com o sexo e subgrupos experimentais relacionados ao tempo de movimentação dentária induzida para análise microscópica do complexo dentinopulpar em molares de rato.

\begin{tabular}{|c|c|c|c|c|c|c|c|c|c|}
\hline Grupos & $\begin{array}{l}\text { sem } \\
\text { MDI }\end{array}$ & $\begin{array}{l}1 \text { dia } \\
\text { MDI }\end{array}$ & $\begin{array}{l}2 \text { dias } \\
\text { MDI }\end{array}$ & $\begin{array}{l}3 \text { dias } \\
\text { MDI }\end{array}$ & $\begin{array}{l}4 \text { dias } \\
\text { MDI }\end{array}$ & $\begin{array}{l}5 \text { dias } \\
\text { MDI }\end{array}$ & $\begin{array}{l}6 \text { dias } \\
\text { MDI }\end{array}$ & $\begin{array}{l}7 \text { dias } \\
\text { MDI }\end{array}$ & Total \\
\hline $\begin{array}{c}\text { número dos } \\
\text { animais }\end{array}$ & 10 & 3 & 3 & 9 & 3 & 9 & 3 & 9 & 49 \\
\hline \multirow{2}{*}{$\begin{array}{l}\text { sexo dos } \\
\text { animais }\end{array}$} & $4 \lesssim$ & 10 & 10 & $3{ }^{\lambda}$ & $1{ }^{\lambda}$ & $3{ }^{\lambda}$ & $1{ }^{\lambda}$ & $4{ }^{\lambda}$ & $18{ }^{\lambda}$ \\
\hline & 6 우 & 2 + & $2 q$ & 6 ㅇ & $2 q$ & $6 q$ & $2 q$ & $5 q$ & 31 우 \\
\hline
\end{tabular}




\subsection{Anestesia dos animais}

Para os procedimentos de instalação dos aparelhos ortodônticos, os animais foram anestesiados com uma única dose contendo a mistura de $1 \mathrm{mlP} / \mathrm{Kg}$ de cloridrato de xilazina (nome comercial Anasedan da marca Purina), um sedativo relaxante muscular analgésico, e cloridrato de ketamina (nome comercial Dopalen também da marca Purina), anestésico geral injetável, ambos os medicamentos de uso veterinário. Injetou-se a mistura anestésica por via intraperitoneal, obtendo-se um período de duas a quatro horas de anestesia ${ }^{53}$.

\subsection{Instalação e ativação dos aparelhos para movimentação dentária induzida}

Após a perda de sentidos dos animais, em decorrência da anestesia, realizava-se o posicionamento em mesa operatória, modificada por Sales ${ }^{81}$, a partir de Houston ${ }^{34}$. Instalaram-se os dispositivos para a movimentação dentária induzida, construídos de acordo com Heller; Nanda ${ }^{33}$, com alguns aprimoramentos desenvolvidos por MartinsOrtiz $^{53}$ em 2004.

Para a instalação do dispositivo ortodôntico, foram essenciais os seguintes componentes e materiais:

$\checkmark \quad$ mesa operatória modificada por Sales ${ }^{81}$, partir de Houston ${ }^{34}$ (Fig. 1A);

$\checkmark$ mola espiralada fechada de 4mm de comprimento com fio de .006 $\times .022$ polegadas, da marca comercial Morelli;

$\checkmark$ fio de amarrilho 0,12 milímetros, fornecidos pela empresa Morelli de materiais ortodônticos;

$\checkmark$ fio de aço inox com 0,25 milimetros, também Morelli;

$\checkmark \quad$ compasso de pontas secas; 
$\checkmark \quad$ compasso de Willis;

$\checkmark \quad$ alicate de corte de amarrilho;

$\checkmark$ pinça de Mathiew, $11 \mathrm{~cm}$;

$\checkmark$ pinça clínica;

$\checkmark$ dobrador de amarrilho;

$\checkmark$ broca diamantada fina $2200 F$ da KG Sorensen;

$\checkmark \quad$ resina composta da marca comercial 3M, Concise Ortodôntico;

$\checkmark \quad$ microbrush, da marca KG brush;

$\checkmark \quad$ compressor e seringa tríplice;

$\checkmark \quad$ caneta de alta rotação Kavo e

$\checkmark \quad$ refletor odontológico. 

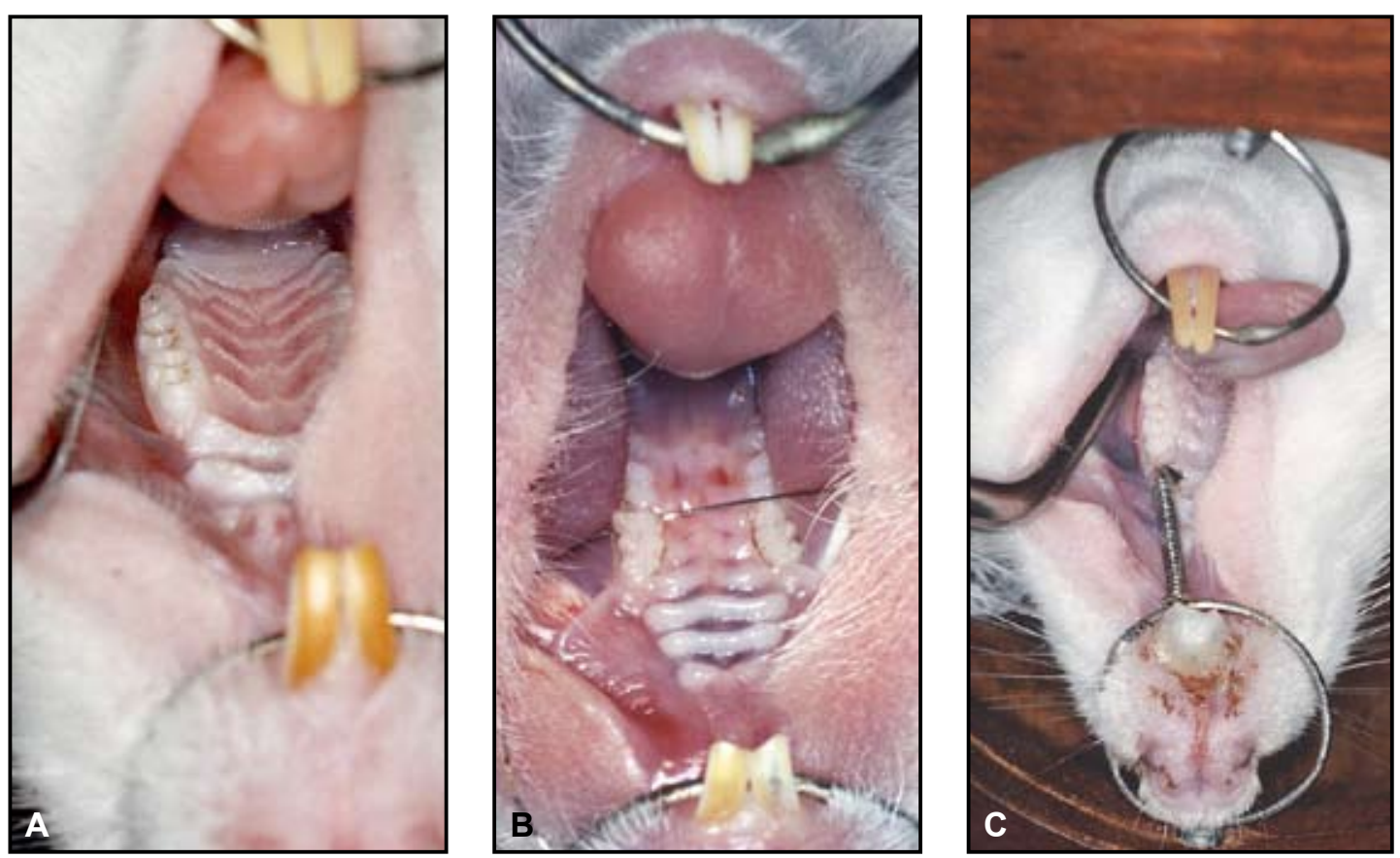

FIGURA 1 - Aspectos e passos da instalação do aparelho para movimentação dentária induzida do primeiro molar superior esquerdo murino como Martins-Ortiz ${ }^{53}$ em 2004.
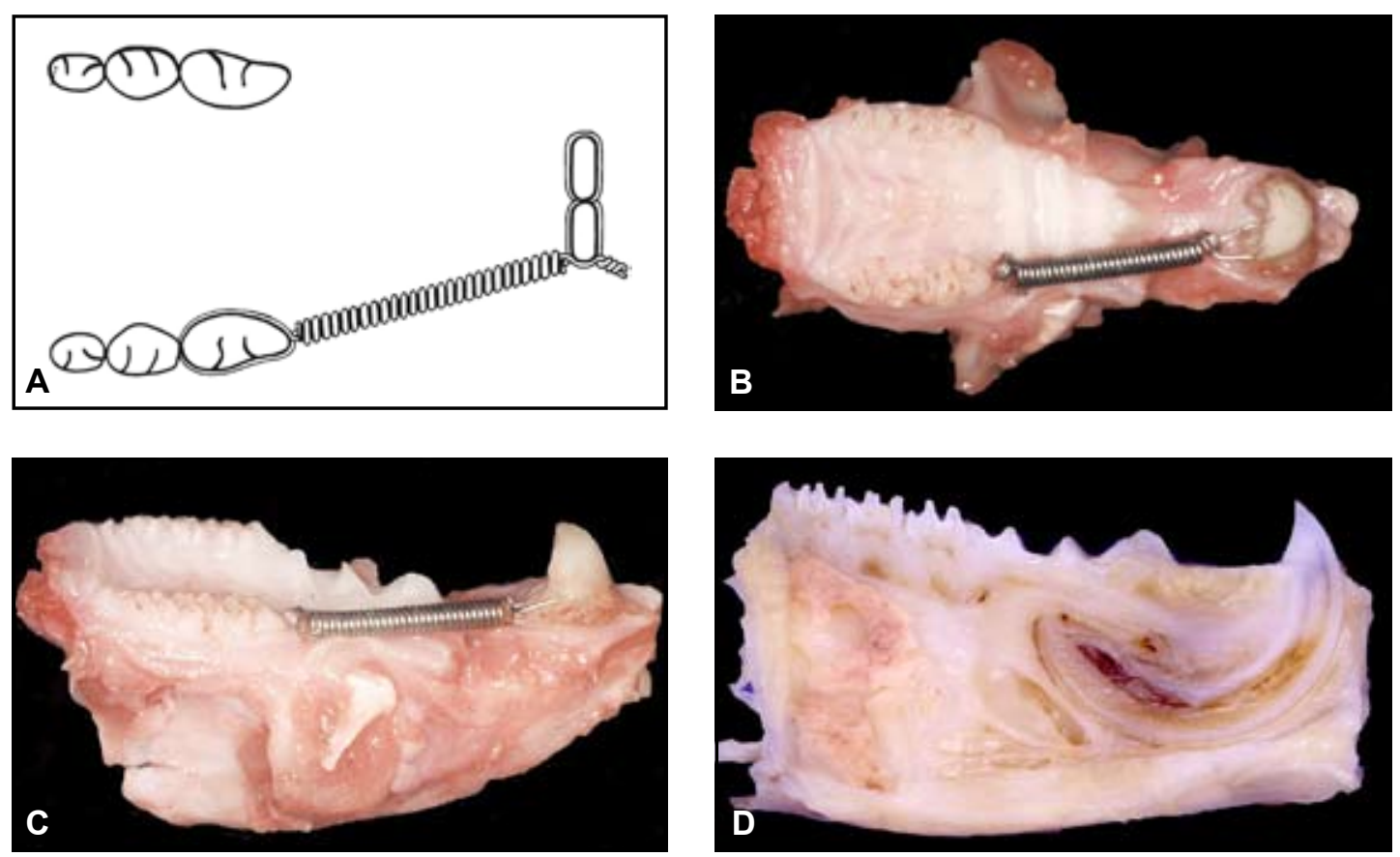

FIGURA 2 - Aparelho para movimentação dentária induzida do primeiro molar superior esquerdo de ratos demonstrando em peças cirúrgicas. Em D, a peça foi desmineralizada e seccionada para inclusão e obtendo cortes teciduais para exame microscópico. 
Cada aparelho instalado nos animais (Figuras 1A, 1B) foi confeccionado metodicamente, seguindo os passos, sempre à luz do refletor odontológico.

\section{Preparo das molas utilizadas.}

- Realizamos três marcas consecutivas no rolo de mola fechada previamente ao corte, utilizando para essa marcação o alicate de corte de amarrilho. A primeira marca, aproximadamente 2 a 3 helicóides à frente da segunda, há exatos $4 \mathrm{~mm}$ da marca anterior, foi aferida com o compasso de pontas secas previamente calibrado pelo compasso de Willis.

- Uma última marca 2 a 3 helicóides após a segunda marca. E assim sucessivamente. Cada mola, então, era composta dos $4 \mathrm{~mm}$ efetivos para a ativação e 2 a 3 helicóides em cada extremidade para a união dos amarrilhos aos dentes.

- Dois segmentos de fio de amarrilho de 0,25mm, de aproximadamente $7 \mathrm{~cm}$ de comprimento, eram amarrados a uma única extremidade da mola e cada segmento era unido em suas pontas para não se soltarem da mola. Uma vez prontas as molas inicíavamos a instalação propriamente dita.

\section{União da mola ao primeiro molar superior esquerdo}

- Utilizando uma pinça de Mathiew e afastando-se a mucosa jugal do rato com uma pinça clínica, inseríamos, inicialmente por lingual e pelo espaço interproximal, entre o primeiro e segundo molares superiores esquerdos, a ponta de um segmento de fio de aproximadamente $7 \mathrm{~cm}$ de amarrilho 0,12 $\mathrm{mm}$. Essa ponta de $5 \mathrm{~mm}$ era previamente manipulada tomando a forma de anzol. Essa passagem requer treinamento para ser realizada com sucesso e com um mínimo de dano aos tecidos periodontais circundantes.

- Uma vez apreendida a ponta desse "anzol" por vestibular do espaço interproximal com a pinça de Mathiew, puxávamos o fio até a metade de seu comprimento. 
- Inserimos a ponta da porção lingual desse segmento de amarrilho à extremidade livre da mola, amarrando-o de forma que a mola se posicionasse por mesial e o mais próximo possível da coroa do primeiro molar superior esquerdo. O fio de amarrilho 0,12mm seria análogo a uma banda, abraçando o primeiro molar superior esquerdo e, ao mesmo tempo, fixando uma das extremidades da mola.

Normalmente, os trabalhos realizam a união da mola ao incisivo superior esquerdo apenas, no máximo, fixando essa união com resina composta. Entretanto, no trabalho piloto, ocorreram dificuldades como quebras dos aparelhos pela interferência dos incisivos inferiores durante a alimentação elou quebra do incisivo superior esquerdo, mesmo triturando a ração ingerida pelos animais. Portanto, no afã de garantir a integridade dos aparelhos e a fidelidade à metodologia empregada, implementamos ainda amarração sobressalente, também com fio $0.25 \mathrm{~mm}$ no incisivo superior direito, conforme descrição a seguir.

\section{União da mola aos incisivos superiores}

- Utilizando uma broca tronco cônica diamantada fina em alta rotação, devidamente refrigerada, realizaram os nas faces distais e mesiais de ambos os incisivos superiores, sulcos de retenção o mais cervical possível. As bordas das retenções apresentavam um ângulo vivo, nunca arredondado, possibilitando maior apreensão do fio.

- Cada segmento de fio 0,25m previamente unido à extremidade da mola, era amarrado aos incisivos. Cada segmento de fio para cada incisivo separadamente, distendendo a mola $2 \mathrm{~mm}$.

- Realizamos a aferição do comprimento da mola em 6mm com o compasso de pontas secas, calibrado pelo compasso de Willis, a cada amarração, sistematicamente, garantindo, assim, o comprimento exato da mola, ao final do procedimento. 
A força despendida por essa distensão da mola sobre o primeiro molar superior esquerdo foi de $75 \mathrm{cN}^{72}$, medida e padronizada previamente com um dinamômetro da marca Morelli de 25 a 250g, devidamente calibrado e aferido. Devido às propriedades do aço, essa força dissipava-se, gradualmente, ao longo dos dias, em que o aparelho permanecia na cavidade bucal.

- Finalmente, depositávamos uma camada de resina composta recobrindo os fios de amarrilho ao redor dos incisivos. Realizávamos também o recobrimento dos fios de amarrilho 0,25mm por lingual até a extremidade da mola, protegendo-a da interferência dos incisivos inferiores durante a alimentação.

A resina depositada sobre os fios de amarrilho $0,25 \mathrm{~mm}$, por lingual dos incisivos até a extremidade da mola, serviu-nos de alarme quanto a uma quebra dos aparelhos. Todos os dias, os ratos eram examinados quanto ao correto posicionamento do dispositivo ortodôntico (Figuras $1 \mathrm{~A}$ e 1B). Os espécimes, que não mais apresentassem a resina em posição, eram anestesiados mais uma vez para um novo recobrimento de resina nessa posição, evitando o contato direto dos incisivos inferiores sobre o aparelho.

Dessa forma, não ocorreu nenhuma quebra de aparelho durante o período experimental nem tampouco se realizou qualquer ativação adicional. O correto posicionamento dos aparelhos era conferido diariamente, e não ocorreu nenhuma fratura.

Os incisivos superiores serviram como ancoragem para o movimento mesial do primeiro molar superior esquerdo, não sendo avaliados neste estudo.

Conforme mencionado, alguns segmentos de molares superiores do lado direito foram preparados para a observação microscópica, objetivando verificar as características advindas apenas do medicamento empregado nas estruturas ósseas e dentárias, sem a interferência da movimentação dentária induzida. 


\subsection{Morte dos animais, obtenção e preparo histotécnico das peças cirúrgicas}

Ao término dos períodos experimentais, os animais morriam por dose excessiva da mistura anestésica ketamina e xilazina. Em seguida, utilizando tesouras Íris e Metzembaum, os animais foram decapitados procedendo com a dessecação, removendo-se os componentes epiteliais e musculares circundantes à maxila. Padronizamos o "modus operandi" e a quantidade de dessecação, evitando que uma quantidade excessiva de tecido remanescente interferisse na velocidade de desmineralização intergrupos ou interespécimes.

As maxilas foram colocadas em uma solução tamponada de formol a 10\%, para fixação, permanecendo nessa solução até a obtenção de todos os espécimes do experimento para a realização simultânea da desmineralização das peças.

Realizamos a desmineralização em solução de Morse, por um período de uma semana, sendo a solução trocada a cada dois dias e o ponto de desmineralização verificado todos os dias. Como a desmineralização nessa solução é extremamente rápido, foi necessária, por vezes, a verificação do processo em algumas peças, a cada 6 ou 12 horas, para a obtenção do ponto perfeito de corte. O julgamento do ponto de corte, utilizando a solução desmineralizadora de Morse, demandou treinamento prévio e controle minucioso para evitar a perda de peças.

Para observação imediata, utilizamos uma lupa. Os remanescentes do aparelho foram removidos apenas após a desmineralização das peças com alicate de corte de amarrilho.

Utilizando uma lâmina de barbear para cada peça, realizamos o preparo macroscópico das maxilas desmineralizadas, que se constituiu da seguinte seqüência:

1. um corte inicial frontal $4 \mathrm{~mm}$ à frente dos primeiros molares superiores (à frente da segunda prega palatina anterior aos molares superiores), com uma inclinação de aproximadamente $45^{\circ}$, dividindo a maxila em dois segmentos, anterior e posterior; 
2. um corte no sentido ântero-posterior, perpendicular ao plano oclusal no centro do palato eqüidistante dos molares superiores esquerdos e direitos, separando as hemimaxilas. Em seguida, procedíamos à toilette das peças;

3. um corte vertical bastante conservador, paralelamente ao longo eixo do primeiro molar, determinando o plano de corte por vestibular de cada segmento de molares superiores, no sentido mesiodistal (Figura 1B).

No estudo piloto, verificamos que é extremamente arriscado realizar esse corte dividindo os molares ao meio no sentido mesiodistal. Essa manobra pode comprometer a visualização da área adequada para a análise microscópica, em virtude do posicionamento do bloco no micrótomo;

4. complementamos o acabamento das peças com um ajuste do plano de corte com delicado refinamento. Esse ajuste envolveu, no mesmo plano, pelo menos, as raízes mesial e distal do primeiro molar superior.

Foi possível observarmos, macroscopicamente e sem lupa, o aumento do espaço interproximal entre o primeiro e segundo molar superior esquerdo, nos espécimes submetidos à movimentação dentária induzida por mais de cinco dias.

Em seguidam aos cortes macroscópicos, as peças foram armazenadas individualmente, juntamente com as respectivas identificações, em formol a 10\% e desidratadas em banhos sucessivos de álcool e parafina.

Incluirmos os segmentos de molares superiores parafinizados no sentido mesiodistal, paralelamente ao longo eixo dos primeiros molares (Figura 1B). As peças foram ajustadas utilizando uma pinça clínica e realizando uma suave pressão do plano de corte de encontro no fundo da caixa.

Realizamos o posicionamento dos blocos no micrótomo, de forma que a primeira parte desgastada fosse a menos importante, envolvendo o terceiro e o segundo molar até que o corte englobasse toda a peça e atingisse a região do primeiro molar 
superior. Controlarmos os cortes passo a passo, observando a seqüência no microscópio ótico, mesmo sem coloração e orientando o aprimoramento do posicionamento do bloco. Dessa forma, possibilitamos a obtenção das raízes mesial e distal do primeiro molar superior em um mesmo corte.

Em cada lâmina, visualizamos cinco cortes, em média. Essas lâminas receberam coloração pelo método hematoxilina-eosina de Harris e Lison. Após a montagem das lamínulas de vidro em resina e secagem, acondicionamos as lâminas identificadas e os respectivos cortes corados, em caixas apropriadas, armazenadas em ambiente seco e fresco. 

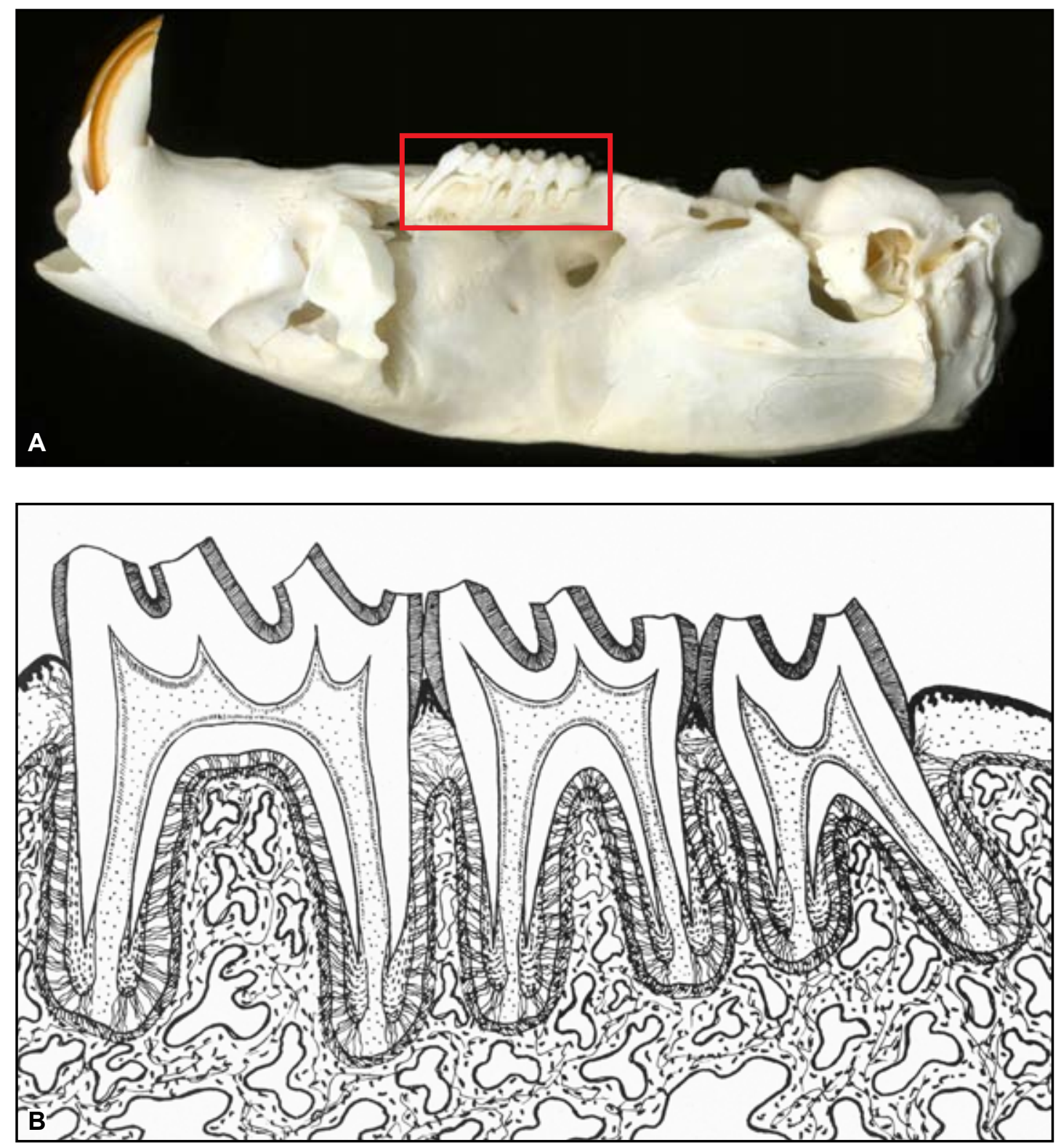

FIGURA 3 - Morfologia e relação dos tecidos dentários murinos com o tecido ósseo alveolar e gengival. O esmalte apresenta-se preenchido, a dentina branca e o cemento pontilhado. Destaca-se a forma de clava das raízes dos molares em função da espessura do cemento apical. 


\subsection{Preparação, condições e critérios para a análise microscópica}

Examinarmos os cortes teciduais, provenientes do processamento histotécnico, com microscópio binocular Olympus $\mathrm{CH}-2$. Ao lado do examinador estavam as fichas e as tabelas de registros dos dados.

Os primeiros molares superiores murinos esquerdos, com ou sem movimentação dentária induzida, foram examinados para diagnosticarmos estado pulpar quanto a sinais ou critérios morfológicos que denotem envelhecimento pulpar precoce, decorrente das alterações endócrinas que os pacientes são portadores. Entre os critérios, incluímos o que segue.

$\checkmark$ Redução da celularidade pulpar: focal ou generalizada.

$\checkmark$ Aumento do fibrosamento pulpar: focal ou generalizado.

$\checkmark \quad$ Hialinizaçao pulpar: focal ou generalizada.

$\checkmark \quad$ Nódulos pulpares:

- quanto à localização: coronários ou radiculares;

- quanto ao número: único ou múltiplos;

- calcificação difusa da polpa: coronária ou radicular;

- metamorfose cálcica da polpa (obliteração total): da câmara pulpar ou do canal radicular.

$\checkmark$ Desorganização da camada odontoblástica.

$\checkmark$ Deposição de dentina reacional nas paredes pulpares: da câmara pulpar ou do canal radicular.

$\checkmark \quad$ Distúrbios circulatórios:

- congestão vascular; 
- hemorragia: focal ou generalizada;

- trombose.

$\checkmark$ Hialinização segmentar do ligamento periodontal da raiz distal: presente ou ausente.

$\checkmark \quad$ Reabsorção dentária: presente ou ausente.

$\checkmark \quad$ Reabsorção dentária: cementária ou dentinária.

$\checkmark$ Reabsorção óssea induzida pela MDI: frontal ou a distância.

Os registros referentes foram estabelecidos em quadros especificamente elaborados para esse fim. Após a análise, os dados foram tabulados em forma de tabelas e gráficos.

\subsection{Análise estatística}

As análises estatísticas utilizadas para a verificação das diferenças intergrupos foram os seguintes testes não paramétricos: quiquadrado, Kruskal-Wallis e Dunn.

Decorridos 30 dias da primeira análise microscópica, selecionamos, aleatoriamente, 30 espécimes e comparamos os resultados da primeira e da segunda análise, obtendo-se o índice Kappa de avaliação intra-examinador. Os dados para a interpretação qualitativa do resultado desse teste apresentam-se a seguir:

QUADRO 1 - Quadro de transformação e interpretação do índice Kappa dos resultados quantitativos em variáveis qualitativas de acordo com Landis; $\mathrm{Koch}^{48}$.

\begin{tabular}{|c|c|}
\hline Coeficiente Kappa & Nível de concordância \\
\hline$<0,00$ & - \\
\hline $0,00-0,20$ & Baixo \\
\hline $0,21-0,40$ & Médio \\
\hline $0,41-0,60$ & Moderado \\
\hline $0,61-0,80$ & Substancial \\
\hline $0,81-1,00$ & Quase perfeito \\
\hline
\end{tabular}




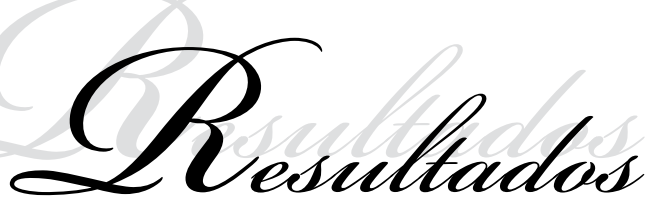




\section{Resultados}

\subsection{Análise microscópica: grupo controle e grupo experimental}

Nos dois grupos, controle e experimental, e nos vários períodos de observação, notamos uma uniformidade na morfologia da polpa dentária. Em ambos os grupos, os vasos estavam, geralmente, congestos e preenchidos por componentes sangüíneos, predominantemente por eritrócitos.

A camada odontoblástica, eventualmente, apresentava células com vacuolização e alguns pontos de ruptura em sua continuidade, associados a artefatos de técnica. Essas observações sobre a normalidade morfológica pulpar são válidas para toda a polpa, desde a região coronária até a região apical.

Na parede interna da dentina, voltada para a polpa dentária, não havia espessamento da camada de pré-dentina e sinais morfológicos de dentina reacional que indicassem qualquer efeito pulpar da força exercida na movimentação dentária induzida experimentalmente.

Nos tecidos periodontais cervicais da face mesial da raiz mesial do primeiro molar superior dos ratos, os fenômenos observados foram compatíveis com os encontrados na movimentação dentária induzida por forças biologicamente aceitáveis ${ }^{18,51}$, incluindo áreas focais de hialinização e reabsorção óssea frontal e reorganização periodontal, a partir do quinto dia de observação.

O foco das observações periodontais foi a região cervical medial da raiz distal do primeiro molar superior, na qual o modelo experimental utilizado gera forças intensas, comprovadas pela indução de áreas hialinas segmentares, reabsorção óssea a distância e reabsorção radicular. Esses três sinais morfológicos indicam que a força foi muito efetiva e, se houver efeito pulpar, esse efeito haveria de se manifestar morfologicamente. 
Nos três primeiros dias, predominaram a hialinização cervical segmentar do ligamento periodontal; a partir do quarto e quinto dia, associa-se a reabsorção óssea frontal e predominantemente a distância, quando, então, também observamos exuberantes áreas de reabsorção radicular.

No terço apical, o periodonto se apresentava comprimido, especialmente na face distal da raiz distal do primeiro molar superior murino; no periodonto apical, entretanto, e na região correspondente ao coto periodontal, não foram observadas alterações morfológicas, apenas, eventualmente, notávamos alguns vasos congestos.

Na tabela 2, o número de espécimes com cada um desses fenômenos para cada período de observação está apresentado.

As fotomicrografias apresentadas nas figuras 3 a 8 permitem analisar alguns desses principais fenômenos descritos e utilizados como parâmetros de observação.

TABELA 2 - Freqüência dos fenômenos pulpares microscopicamente observados em cada grupo experimental de movimentação dentária induzida em primeiros molares superiores de ratos

\begin{tabular}{|c|c|c|c|c|c|c|c|c|}
\hline \multirow{2}{*}{ Fenômenos } & $\begin{array}{c}\text { S/ } \\
\text { MDI }\end{array}$ & $\begin{array}{c}\mathbf{1} \\
\mathbf{d i a}\end{array}$ & $\begin{array}{c}\mathbf{2} \\
\text { dias }\end{array}$ & $\begin{array}{c}\mathbf{3} \\
\text { dias }\end{array}$ & $\begin{array}{c}\mathbf{4} \\
\text { dias }\end{array}$ & $\begin{array}{c}\mathbf{5} \\
\text { dias }\end{array}$ & $\begin{array}{c}\mathbf{6} \\
\text { dias }\end{array}$ & $\begin{array}{c}\mathbf{7} \\
\text { dias }\end{array}$ \\
\cline { 2 - 9 } & $\mathbf{n = 1 0}$ & $\mathbf{n = 3}$ & $\mathbf{n = 3}$ & $\mathbf{n = 9}$ & $\mathbf{n = 3}$ & $\mathbf{n = 9}$ & $\mathbf{n = 3}$ & $\mathbf{n = 9}$ \\
\hline Vacuolização celular & 2 & 0 & 1 & 2 & 0 & 0 & 0 & 0 \\
\hline Túbulos com núcleos & 0 & 0 & 0 & 0 & 0 & 0 & 0 & 0 \\
\hline Celularidade reduzida & 0 & 0 & 0 & 0 & 0 & 0 & 0 & 0 \\
\hline Fibrosamento aumentado & 0 & 0 & 0 & 0 & 0 & 0 & 0 & 0 \\
\hline Hialinização & 0 & 0 & 0 & 0 & 0 & 0 & 0 & 0 \\
\hline Nódulos pulpares & 1 & 0 & 0 & 0 & 0 & 0 & 0 & 0 \\
\hline Calcificação difusa & 0 & 0 & 0 & 0 & 0 & 0 & 0 & 0 \\
\hline Dentina reacional & 0 & 0 & 0 & 0 & 0 & 0 & 0 & 0 \\
\hline Congestão vascular & 10 & 3 & 2 & 8 & 3 & 9 & 2 & 9 \\
\hline Hemorragia & 0 & 0 & 0 & 0 & 0 & 0 & 0 & 0 \\
\hline Trombose & 0 & 0 & 0 & 0 & 0 & 0 & 0 & 0 \\
\hline
\end{tabular}

* Significante para nível de $5 \%$ em relação ao Grupo Controle sem MDI

** Significante para nível de 10\% em relação ao Grupo Controle sem MDI 
TABELA 3 - Freqüência dos fenômenos periodontais microscopicamente observados em cada grupo experimental de movimentação dentária induzida em primeiros molares superiores de ratos.

\begin{tabular}{|c|c|c|c|c|c|c|c|c|}
\hline Grupos & $\begin{array}{c}\text { S/ } \\
\text { MDI }\end{array}$ & $\begin{array}{c}1 \\
\text { dia }\end{array}$ & $\begin{array}{c}2 \\
\text { dias }\end{array}$ & $\begin{array}{c}3 \\
\text { dias }\end{array}$ & $\begin{array}{c}4 \\
\text { dias }\end{array}$ & $\begin{array}{c}5 \\
\text { dias }\end{array}$ & $\begin{array}{c}6 \\
\text { dias }\end{array}$ & $\begin{array}{c}7 \\
\text { dias }\end{array}$ \\
\hline Fenômenos & $\mathrm{n}=\mathbf{1 0}$ & $\mathbf{n}=\mathbf{3}$ & $\mathbf{n}=\mathbf{3}$ & $\mathbf{n}=\mathbf{9}$ & $\mathbf{n}=\mathbf{3}$ & $\mathbf{n}=\mathbf{9}$ & $\mathbf{n}=\mathbf{3}$ & $\mathbf{n}=\mathbf{9}$ \\
\hline Hialinização focal & 0 & 2 & 0 & 2 & 0 & 2 & 0 & 3 \\
\hline Hialinização segmentar & 0 & 1 & 3 & $7 *$ & 3 & $7 *$ & 3 & 6 \\
\hline Reabsorção óssea frontal & 0 & 0 & 1 & 3 & 1 & 2 & 0 & 3 \\
\hline $\begin{array}{c}\begin{array}{c}\text { Reabsorção óssea a } \\
\text { distância }\end{array} \\
\end{array}$ & 0 & 0 & 0 & $6 * *$ & 2 & $7 *$ & 3 & $6 * *$ \\
\hline Reabsorção radicular & 0 & 0 & 0 & 0 & 1 & $8^{*}$ & 3 & $9 *$ \\
\hline
\end{tabular}

* Significante para o nível de 5\% em relação ao Grupo Controle sem MDI

** Significante para o nível de 10\% em relação ao Grupo Controle sem MDI 

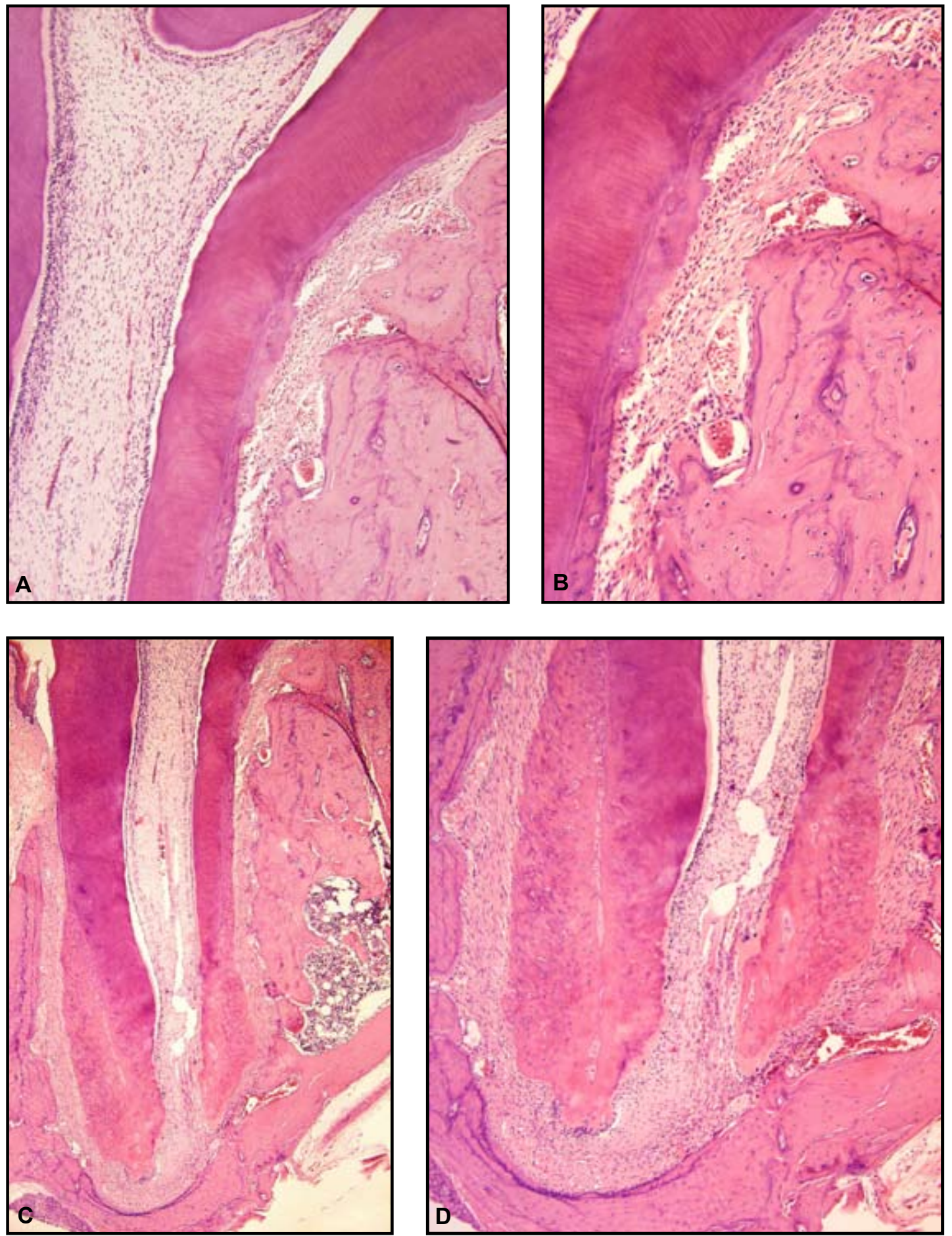

FIGURA 3 - Aspectos microscópicos pulpares e periodontais normais, sem movimentação dentária, da raiz mesial do molar murino, (HE - aumentos originais: $\mathrm{A}$ e $\mathrm{D}=40 \mathrm{X} ; \mathrm{B}=100 \mathrm{X} ; \mathrm{C}=20 \mathrm{X}$ ). 

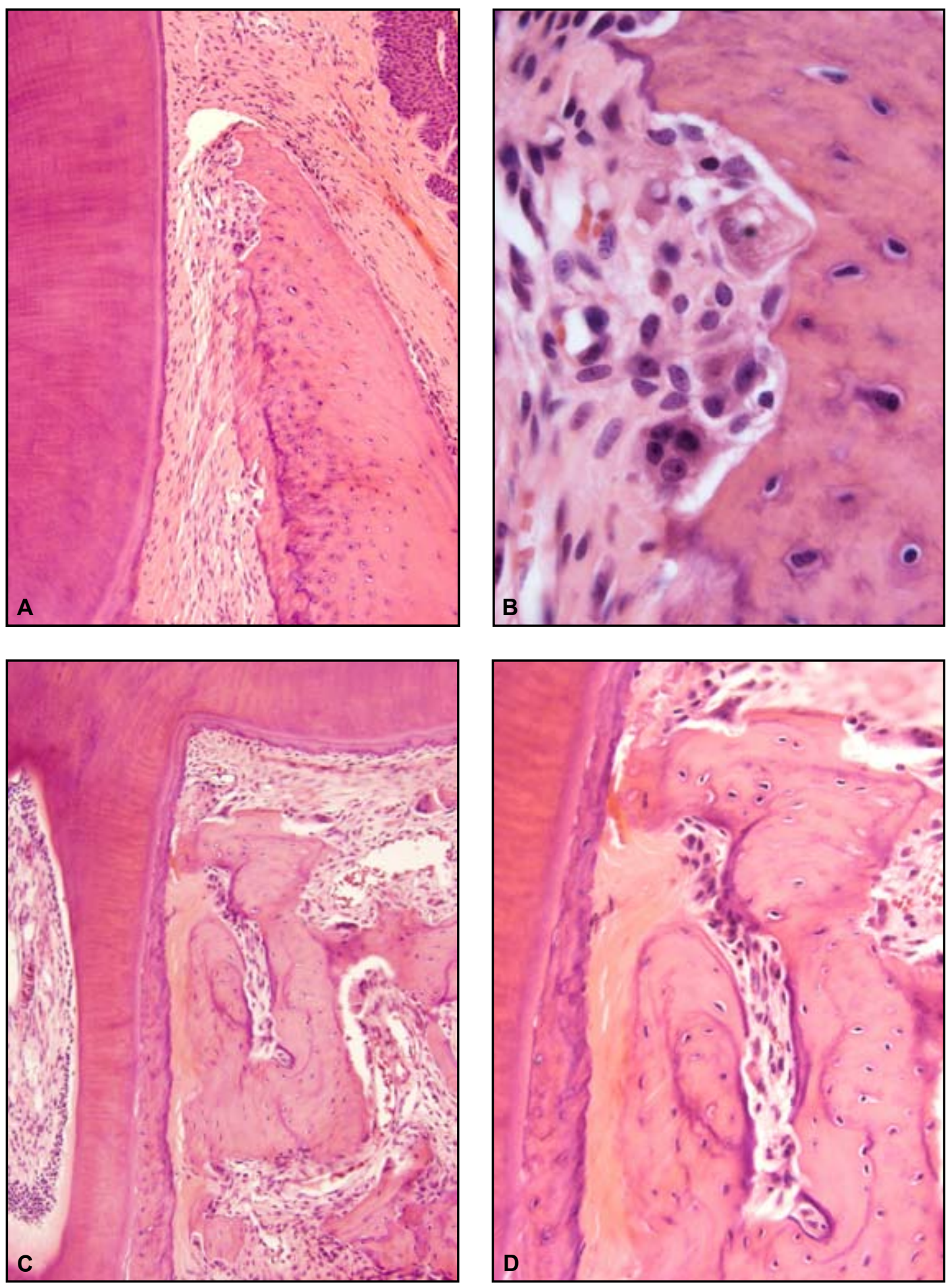

FIGURA 4 - Alterações morfológicas induzidas na região cervical da raiz mesial (A e B), submetida a forças moderadas com reabsorção óssea frontal; na região cervical da raiz distal, submetida a forças intensas (C e D); no Grupo Experimental, após 3 dias de movimentação dentária induzida. Destacamos que a polpa apresenta aspecto de normalidade (H.E. - aumentos originais A e C = 40X, B e D = 100X). 


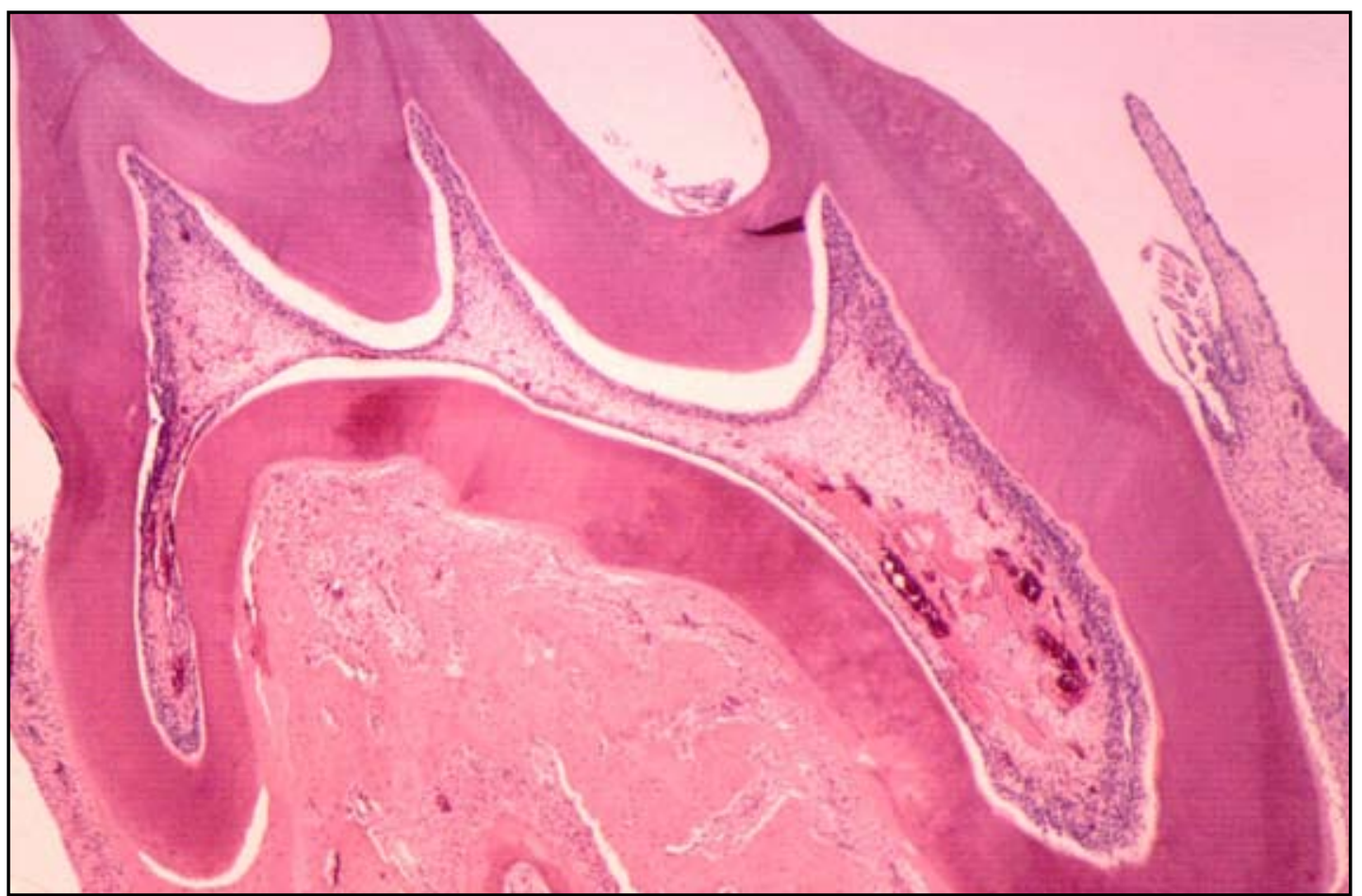

FIGURA 5 - Aspectos microscópicos dos fenômenos observados na polpa dentária e na região periodontal cervical, submetida a forças intensas na face mesial da raiz distal do primeiro molar murino, após 4 dias de movimentação dentária induzida. Observamos a hialinização segmentar do ligamento periodontal. A polpa apresenta aspectos de normalidade. A congestão vascular na polpa dentária observada decorre de procedimentos operatórios na coleta do material para processamento histotécnico. (H.E. - aumento original: 10X).
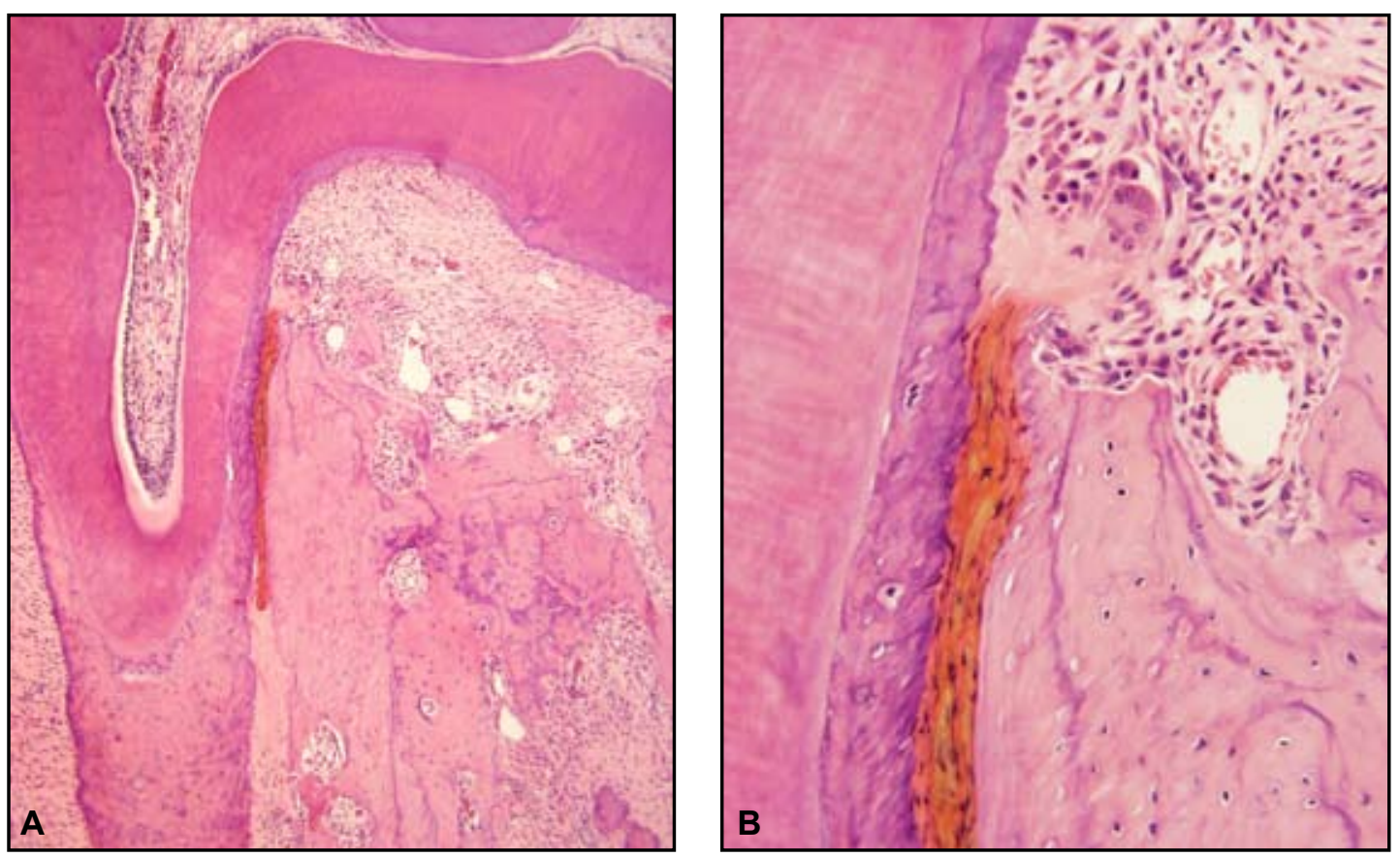

FIGURA 6 - Aspectos microscópicos dos fenômenos observados na polpa dentária e na região periodontal cervical, submetida a forças intensas na face mesial da raiz distal do primeiro molar murino, após 5 dias de movimentação dentária induzida. Observammos a hialinização segmentar do ligamento periodontal e a reabsorção óssea a distância, caracterizada pela grande quantidade de unidades osteorremodeladoras nos espaços medulares e na face periodontal do osso alveolar. A polpa apresenta aspectos de normalidade. A congestão vascular na polpa dentária observada decorre de procedimentos operatórios na coleta do material para processamento histotécnico. (H.E. - aumentos originais: A=20X; $B=40 X$ ). 

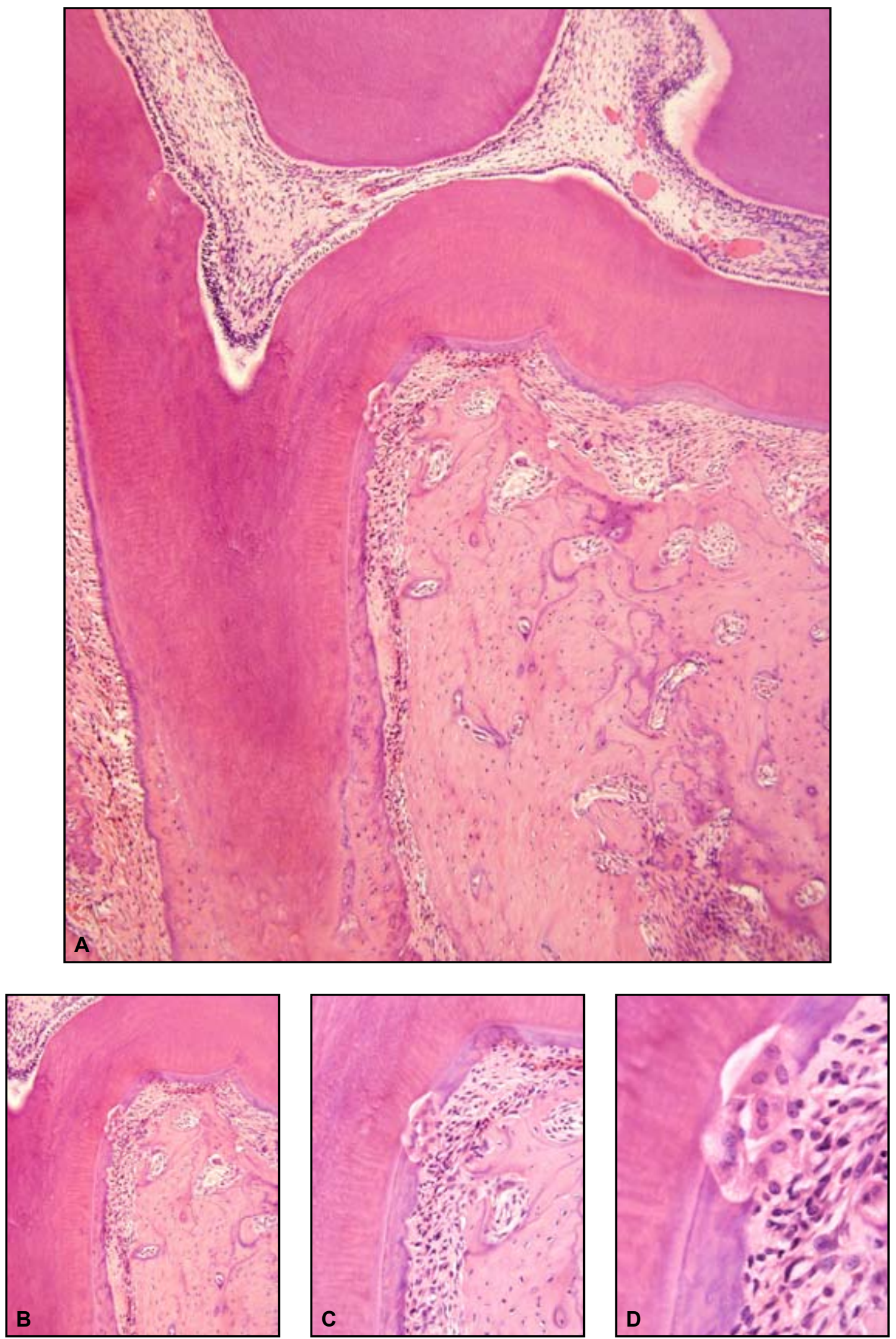

FIGURA 7 - Aspectos microscópicos dos fenômenos observados, na área cervical, submetida a forças intensas, na face mesial da raiz distal do primeiro molar murino, após 7 dias de movimentação dentária induzida. Observamos a fagocitose da hialinização segmentar do ligamento e exuberante reabsorção radicular, com diversas unidades osteorremodeladoras (H.E. - aumentos originais: $-\mathrm{A}=10 \mathrm{X}, \mathrm{B}=20 \mathrm{X}, \mathrm{C}=40 \mathrm{X}, \mathrm{D}=100 \mathrm{X}$ ). 

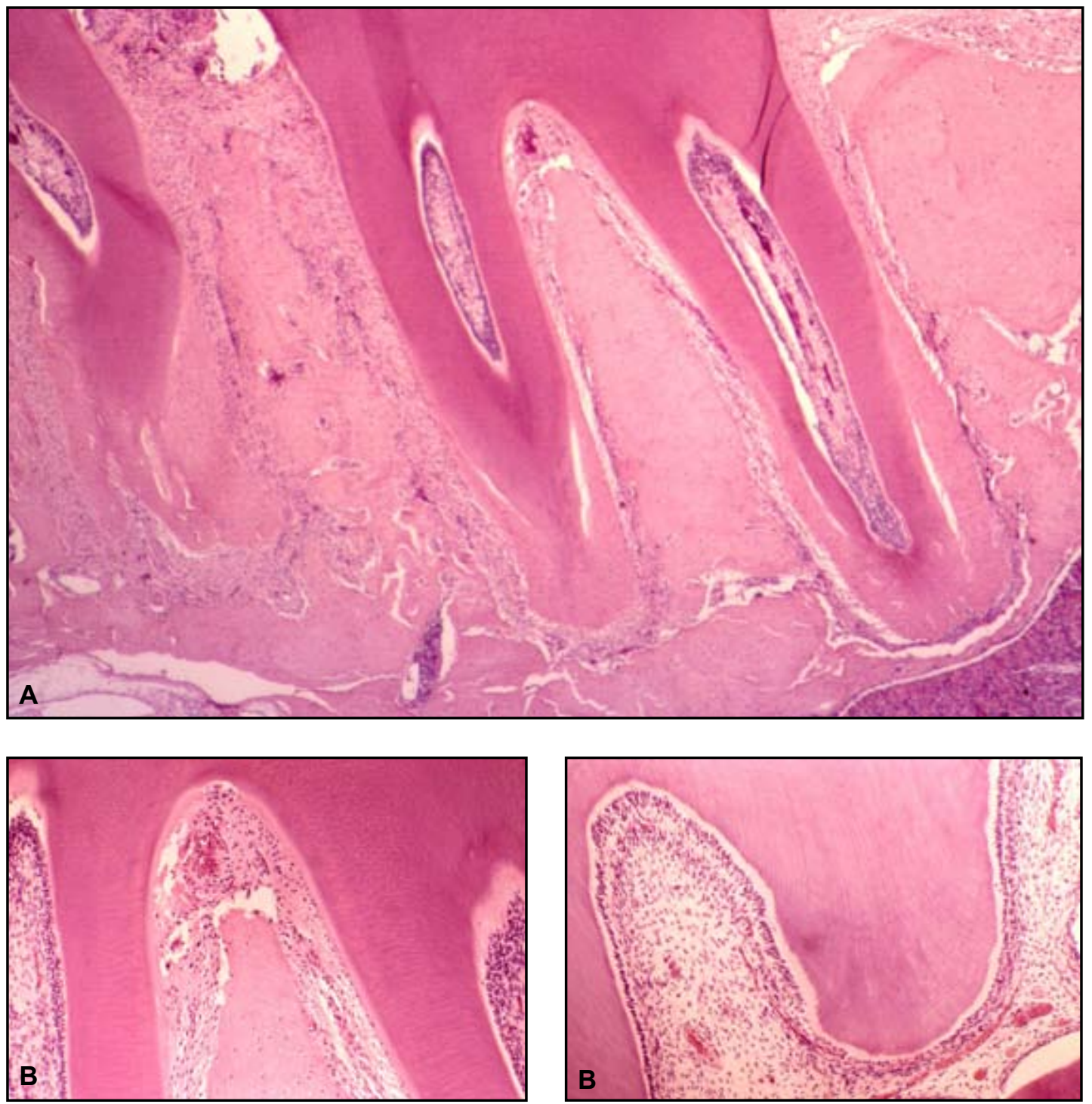

FIGURA 8 - Aspectos microscópicos dos fenômenos observados, na área cervical, submetida a forças intensas, na face mesial da raiz distal do primeiro molar murino, após 7 dias de movimentação dentária induzida. Observamos a morte de cementoblastos e, ainda, a desorganização estrutural do ligamento periodontal. A polpa apresenta-se normal na região coronária, em C, e.cervical, em B. (H.E. - aumentos originais: $\mathrm{A}=10 \mathrm{X}, \mathrm{B}=20 \mathrm{X}, \mathrm{C}=40 \mathrm{X}$ ).

\subsection{Análise estatística}

Aplicamos o índice Kappa para a análise da calibração intra-examinador, sob nova leitura de 30 dos cortes microscópicos, exaustivamente conferidos na checagem dos critérios de observação e determinação do escores. O coeficiente de concordância apresentou o valor de 0,83 que, de acordo com o quadro de transformação (Quadro $1)^{47}$, corresponde, qualitativamente, a um nível quase perfeito.

Os testes estatísticos não paramétricos, quiquadrado, Kruskal-Wallis e Dunn, 
foram aplicados para os aspectos pulpares e periodontais em virtude da observação de qualquer alteração microscópica intergrupos. Os critérios considerados na análise estatística pulpar foram: a vacuolização celular, presença de nódulos pulpares e congestão vascular. Os aspectos relacionados a túbulos com núcleos, celularidade reduzida, fibrosamento aumentado, hialinização, calcificação difusa, dentina reacional, hemorragia e trombose, não foram avaliados estatisticamente, uma vez que permaneceram totalmente inalterados, como demonstrado na Tabela 3.

Os critérios considerados na análise microscópica periodontal foram: a hialinização focal do ligamento periodontal, hialinização segmentar, reabsorção óssea frontal, reabsorção óssea a distância e reabsorção dentária (Tabela 3 e Anexos).

Como podemos observar na Tabela 3 e nos Anexos, não houve diferença estatisticamente significante intergrupos quando da avaliação microscópica da polpa. Os grupos controle e com movimentação dentária induzida demonstraram-se estatisticamente iguais.

Quanto à avaliação dos fenômenos microscópicos periodontais, pudemos constatar diferenças estatisticamente significantes entre os grupos controle e com movimentação dentária induzida (Tabela 3 e Anexos).

Os resultados estatísticos não indicaram diferença intergrupos quanto à hialinização segmentar do ligamento periodontal, mas apresentaram significância quanto à hialinização segmentar aos 3 e 5 dias de movimentação dentária induzida em comparação com o grupo controle (Tabela 3 e Anexos).

A análise da presença de reabsorção óssea frontal não se demonstrou significante entre os grupos, entretanto, a reabsorção óssea a distância apresentou-se significantemente diferente do grupo controle, principalmente, aos cinco dias de movimento dentário induzido. Para um nível de significância um pouco menos exigente de $10 \%$, podemos considerar diferença estatística entre os três grupos movimentados ortodonticamente e o grupo controle, confirmando a efetividade da força ortodôntica e do 
movimento dentário (Tabela 3 e Anexos).

Os resultados mais significantes demonstrados pelos testes estatísticos foram quanto à presença de reabsorção dentária. Com uma diferença intergrupos de p menor que 0.000000 , os grupos movimentados por 5 e 7 dias apresentaram-se estatisticamente diferentes do grupo controle e do movimentado por três dias. Pudemos detectar reabsorções dentárias, típicas do emprego de forças intensas na movimentação ortodôntica, contudo, a polpa permaneceu inalterada estatisticamente (Tabela 3 e Anexos). 
Oiscussão 


\section{Discussão}

\section{Da nomenclatura, conceitos e critérios utilizados}

\subsection{Movimento ortodôntico e movimento dentário induzido}

O conhecimento da biopatologia da movimentação dentária induzida facilita a compreensão das pequenas e grandes variações clínicas. E leva-nos a trabalhar com tranqüilidade e segurança frente a certas condições sistêmicas e locais, mesmo que fora de um contexto de completa normalidade. No termo "movimentação dentária induzida" estão incluídos todos os tipos de movimento dentário provocado, não exclusivamente com finalidade ortodôntica. Muitos movimentos dentários induzidos têm outras finalidades clínicas, terapêuticas, inclusive experimentais, e os fenômenos biológicos envolvidos são os mesmos. O movimento dentário induzido experimentalmente, por exemplo, não revela finalidade ortodôntica.

Em 2005, Consolaro ${ }^{17}$ diferenciou movimento dentário induzido e movimento ortodôntico: Por definição, o adjetivo "ortodôntico" se aplica àquilo relativo à Ortodontia. O movimento ortodôntico é realizado com fios ortodônticos e será considerado ortodôntico se as movimentações dentárias objetivarem a correção de problemas estéticos e funcionais aos níveis dentário e facial. Percebe-se, então, o movimento ortodôntico como um movimento dentário especifico na medida em que apresenta objetivos bem definidos.

O movimento dentário induzido, por definição, não é fisiológico, como se estabelece para o movimento de erupção dos dentes ou seus movimentos de deslocamento durante o processo de crescimento. O movimento dentário induzido representa um movimento desencadeado por outros estímulos externos aos dentes e ossos, normalmente mecânicos, advindos de forças liberadas geralmente por dispositivos adaptados aos dentes. 
Confrontando-se os termos, movimento ortodôntico e movimento dentário induzido, podemos dizer que o movimento ortodôntico resulta da terapia ortodôntica e corresponde a um movimento dentário induzido.

O movimento dentário induzido não corresponde necessariamente a um movimento ortodôntico, uma vez que seus objetivos podem ser outros não definidos como ortodônticos, ou seja, de correção de alterações dentomaxilofaciais.

Quando se realiza um estudo experimental em animais, o objetivo da movimentação dentária realizada está em verificar as alterações nos tecidos dentários envolvidos. A definição mais apropriada para esse tipo de deslocamento é movimento dentário induzido, mesmo que se utilize um aparelho normalmente empregado em Ortodontia. O dispositivo utilizado, mesmo assim não poderia ser definido como aparelho ortodôntico se considerarmos o preciso significado das palavras.

\subsection{Polpa dentária e complexo dentinopulpar}

Originariamente, a polpa e a dentina constituem uma unidade estrutural e funcional, pois, a papila dentária ao mesmo tempo em que dá origem à polpa dentária permite também levar à formação da dentina. A dentina constitui o produto de síntese das células pulpares, deixando no seu interior prolongamentos citoplasmáticos, em torno dos

quais se formam os túbulos dentinários. Entre as finalidades desses prolongamentos, está manter o equilíbrio hídrico e iônico da dentina bem como propiciar mecanismos de defesa frente a agressores externos.

No estudo da evolução das alterações dentárias, próprias da idade e das patologias inflamatórias induzidas por agentes físicos, químicos e/ou bacterianos, torna-se impossível separar a polpa da dentina. A compreensão desses processos requer o conceito de unidade estrutural e funcional do ponto de vista embriológico.

No diagnóstico, tratamento e prognóstico das doenças que afetam o dente de- 
vem considerar a polpa separadamente da dentina, porque isso permite determinar o grau de profundidade e a espessura dentinária remanescente nos preparos cavitários e protéticos, a capacidade de retenção e de suporte mecânico da estrutura dentária bem como a necessidade e a possibilidade de proteção pulpar em procedimentos clínicos operatórios. Delinear e prever os limites entre a dentina e a polpa significa estabelecer parâmetros para certas condutas terapêuticas e prognósticas.

Adotamos o termo complexo dentinopulpar para nos referirmos a questões embriológicas e funcionais; entretanto, para conduta terapêutica, usam os termos dentina e polpa como tecidos topograficamente distintos.

\subsection{Estímulo e agressão: tipos de respostas celulares induzidas}

Estímulo ou agressão em biologia são tenuamente delineados. A intensidade e a duração de um estímulo/agressão bem como o tipo de célula e a sua situação funcional definirão as conseqüências.

A resposta celular e tecidual frente a um estímulo/agressão passa por várias vias metabólicas e processos extracelulares. A mensuração mais comumente utilizada para se avaliar um maior ou menor grau de agressão celular e tecidual tem sido a inflamação. Entretanto, alterações no metabolismo celular podem ser diagnosticadas mais precocemente como níveis enzimáticos intra e extracelulares, o mesmo ocorrendo com os níveis locais de mediadores químicos utilizados na intercomunicação celular13.

A matriz extracelular apresenta-se constituída por glicoproteínas, proteoglicanas, fibras colágenas e elásticas, além de membranas basais. A troca de estímulos pela ação de mediadores químicos sobre as células decorre da difusibilidade e da seletividade da matriz extracelular. Na reparação, por exemplo, a migração, a diferenciação e a síntese celular são dependentes dessas propriedades da matriz extracelular; sem elas, os mediadores não interagirão com os receptores de superfície celular e os estímulos não serão induzidos. Na polpa dentária, o envelhecimento, natural ou acelerado, leva 
à diminuição da capacidade reparatória em decorrência do aumento da densidade da matriz extracelular e da fibrose pulpar. Agressões ou estímulos podem afetar a matriz extracelular.

A morte celular pode ocorrer por diferentes mecanismos e situações. Quando todo o organismo morre, temos a morte somática e necrose "post mortem". Quando a morte celular acontece em células isoladas ou agrupadas, ou mesmo em um órgão por inteiro, mas dentro de um organismo vivo, temos a necrose celular.

A necrose implica a dilaceração celular em função da ruptura da membrana celular, sem a qual as células não sobrevivem, pois, é responsável pelo equilíbrio iônico entre o meio intra e extracelular. Dependendo da intensidade e duração da agressão, a necrose pode ser precedida pela "degeneração", um estádio ainda de reversibilidade celular à normalidade e caracterizado pelos depósitos intracelulares de produtos como, por exemplo, a água, lipídeos e outros. Atualmente, recomenda-se substituir o termo “degeneração" por lesão celular reversível.

A necrose implica a liberação de enzimas para o meio extracelular, digerindo os componentes da matriz e atuando sobre as outras células. A agressão gerada pela necrose leva geralmente à inflamação e não é geneticamente controlada. A necrose celular pode ser determinada pela ação de agentes físicos, como as radiações e traumatismos, de agentes químicos, como os álcalis e ácidos, e de agentes biológicos, como as bactérias, vírus, fungos e parasitas.

\subsection{Vacuolização odontoblástica versus “degeneração” ou alteração hidrópica}

No preparo dos dentes para análise, a fixação adequada da polpa e a desmineralização são pontos críticos de uma avaliação microscópica precisa e confiável. Os cortes devem ser centrais à área exposta da polpa; eles devem ser seriados ou semi- 
seriados, analisados criteriosamente e devem ser os centralmente localizados. Esses cuidados não estão presentes em muitos dos trabalhos que analisam a reação pulpar frente aos movimentos dentários induzidos.

A fixação na avaliação microscópica de polpas constitui um passo técnico críti$\operatorname{co}^{9,87,89,103}$. A densidade da matriz extracelular, aumentada pela desnaturação de proteínas ou diminuída pela ação de enzimas e exsudato, pode ser prejudicada pela fixação inadequada e assim ser sub ou superdimensionada. A fixação com soluções formuladas precisamente e tamponadas é recomendável. A exposição imediata da polpa via secção do terço médio das raízes dentárias também contribui para a rápida fixação pulpar. A fixação por perfusão pode dificultar a avaliação das alterações circulatórias associadas, a relação dos leucócitos com as paredes vasculares bem como o grau de exsudação plasmática. Esses parâmetros quando se encontram em processos inflamatórios de grande extensão ou intensidade não afetam significantemente os resultados, no entanto, na delicada e especializada estrutura pulpar podem ser determinantes. O somatório dos volumes ocupados pelas polpas dentárias em uma pessoa corresponde a $0,76 \mathrm{cc}$; para cada polpa, o volume médio é de $0,02 \mathrm{cc}^{25,26}$, ou seja, na polpa, as alterações, por mais sutis que sejam, devem ser valorizadas.

A experiência do examinador na interpretação de resultados da reação frente ao um material escolhido para os testes, o conhecimento profundo e amplo da biologia do complexo dentinopulpar e suas alterações e variações devem ser requisitos prévios obrigatórios. A formação básica do patologista examinador constitui premissa fundamental para o conhecimento mínimo da biologia celular aplicada ${ }^{13}$.

Ao patologista examinador cabe um elevado grau de exigência com a fixação, microtomia, coloração e critérios de análise. Infelizmente, em boa parte dos trabalhos referentes a esse assunto, esses quesitos deixam muito a desejar e equívocos grosseiros são cometidos, esquecendo-se de que a concessão a critérios e condutas duvidosas atuam contra a credibilidade científica. $\mathrm{Na}$ apresentação do material e métodos e dos 
resultados, a descrição minuciosa e detalhada dos procedimentos e das observações microscópicas são necessárias, de preferência, espécime por espécime, de forma descritiva ou, no mínimo, em tabelas criativas e bem elaboradas. O conteúdo e critérios de diagnóstico para cada fenômeno observado são determinantes passíveis de avaliação, também por parte da comunidade científica.

Vários trabalhos de avaliação geram preocupação pelos resultados, mais especificamente, pela forma como são apresentados esses resultados. As fotomicrografias revelam cortes com vacuolização odontoblástica sendo interpretada como alteração celular induzida por fenômenos vasculares decorrentes da movimentação dentária induzida.

O acúmulo de água no interior do citoplasma celular em forma de vacúolos intracelulares corresponde à hipóxia ou anóxia por falta de fixação adequada. A solução fixadora demora chegar às partes mais coronárias e cervicais do dente extraído; enquanto não chega, as células entram em processo de hipóxia e anóxia com decorrentes lesões celulares, inicialmente, subletais ou reversíveis. Depois de alguns minutos, quando a solução fixadora atua, essas células irão se apresentar com vacuolização citoplasmática. Nos trabalhos sobre movimentação dentária induzida e seus efeitos pulpares, quase todos destacam que essas alterações ocorrem predominantemente nos terços cervicais e coronários da polpa ${ }^{96}$.

\subsection{Odontoblastos no interior dos túbulos dentinários}

$\mathrm{Na}$ interpretação de resultados experimentais em polpas dentárias, é muito importante relevar tanto as considerações de fixação como também de coleta do material. Durante a extração com fórceps e, às vezes, com alavancas, exerce-se uma pressão intrapulpar na região cervical das raízes dos dentes a serem extraídos e nos quais se fará a análise da polpa. Após essa apreensão, a dentina voltará à situação anterior e à 
pressão intrapulpar igualmente; nesse processo, haverá "aspiração" dos odontoblastos para os túbulos ${ }^{71,94,103}$. Em alguns trabalhos, essa observação está incluída como um dos efeitos deletérios do movimento ortodôntico sobre os tecidos pulpares. Nesses estudos, ressalta-se que esse fenômeno ocorre, principalmente, na porção cervical dos dentes analisados, justamente na área referida.

\subsection{Hiperemia e congestão vascular}

Nos trabalhos de avaliação dos efeitos pulpares de movimentação ortodôntica, os fenômenos vasculares decorrentes da movimentação dentária induzida são relevados, especialmente, a vasodilatação e a hiperemia. Esses fenômenos, conceitualmente, são ativos e fisiológicos, ou seja, dinâmicos, não morfológicos e mensuráveis em uma análise microscópica, muito menos ainda de tecidos pulpares. A hiperemia significa aumento da quantidade de sangue para uma determinada área corporal e isso pode ser conseguido de várias maneiras, como a vasodilatação, aumento da velocidade do fluxo e funcionamento contínuo de toda árvore circulatória da região.

$\mathrm{Na}$ análise microscópica de um tecido conjuntivo, não é possível afirmarmos, com um mínimo de precisão, que o tecido está hiperêmico, mas sim que os vasos estão congestos, com sua luz preenchida por elementos sangüíneos individualizados ou sem distinção que caracterizaria a estase. A congestão vascular, por sua vez, não obrigatoriamente, representa a tradução morfológica da hiperemia, ainda mais de uma hiperemia pulpar.

A exodontia constitui manobra cirúrgica, traumática para os tecidos periodontais que serão rompidos, mas, para os tecidos pulpares, haverá um estrangulamento e rompimento no terço apical, juntamente com as manobras preliminares, o que induzirá uma hiperemia ativa e passiva, que pode gerar uma congestão vascular e estase ao analisarmos microscopicamente os tecidos. $\mathrm{Na}$ polpa, por essa razão, recomendamos 
não considerar a vasodilatação, a hiperemia e a estase bem como a própria congestão vascular, como eventos pulpares que possam representar efeitos de agentes externos, como preparo cavitário, material restaurador e movimentação ortodôntica. Infelizmente, a maioria dos trabalhos, relacionados com o tema efeitos pulpares da movimentação ortodôntica, utilizam esses critérios.

\subsection{Designs experimentais de estudos em polpas dentárias}

Em seu " Design for a human pulp study" voltado para o estudo dos efeitos pulpares de procedimentos operatórios e restauradores, Stanley ${ }^{91}$, em 1968, relacioou alguns aspectos experimentais, que, infelizmente, não são relevados na maioria dos trabalhos, sobre a relação alterações pulpares e movimentação ortodôntica. Entre esses critérios de observações clínicas e radiográficas estão:

- números de dentes humanos para cada grupo: entre 15 e 25 espécimes;

- idade dos pacientes: entre 23 a 58 anos de idade as polpas apresentariam o mesmo potencial biológico, mas o ideal idade inferior a 45 anos e, se possível, com variação média de 5 anos;

- tamanho da coroa: o mais uniforme possível entre os espécimes;

- tempo de observação: períodos inferiores a 24h são muito precoces. Os fenômenos iniciais se obtêm no período de 1 a 3 dias; os períodos de 4 a 12 dias devem ser reservados para efeitos tardios.

Quanto aos critérios microscópicos, incluirmos uma classificação que varie de 0 a 3 em seus escores:

$\checkmark \quad$ espessura da dentina; 
$\checkmark$ deslocamento celular;

$\checkmark \quad$ infiltrado inflamatório: severidade, localização e predominância celular;

$\checkmark \quad$ abscesso pulpar;

$\checkmark \quad$ focos de necrose;

$\checkmark \quad$ reparo tardio;

$\checkmark \quad$ restabelecimento da camada odontoblástica;

$\checkmark$ formação de dentina reacional.

Apesar de este trabalho ter utilizado dentes de ratos como modelo animal experimental, em linhas gerais, no que foi possível, procuramos seguir as orientações para os dentes humanos, que foram aplicadas e úteis na análise criteriosa dos estudos realizados e publicados, utilizando dentes humanos para avaliar os efeitos pulpares da movimentação ortodôntica. No trabalho de Subay et al. ${ }^{99}$ em 2001, esses critérios foram exemplarmente seguidos.

\section{Da metodologia empregada}

\subsection{Sobre o modelo experimental: o animal}

A interpretação das mudanças nos dentes e em seus tecidos de suporte, durante o movimento dentário induzido, baseiamo-nos em simulações e nos estudos de modelos experimentais desde Sandstedt ${ }^{82}$ (1901) em cães, Oppenheim ${ }^{70}$ (1911), em $\operatorname{coelhos}^{4}$, gatos $^{22}$, posteriormente, em macacos ${ }^{18} \mathrm{e}$, mais freqüente e atualmente, em $\operatorname{ratos}^{1,2,9,36,45,50,51,55,75,84,85,101,105,109}$. Nos ratos, o primeiro molar é o dente movimentado pela ativação de mola ancorada nos incisivos. Os molares murinos são bem menos volumosos que os incisivos e apresentam 5 a 6 raízes cuja formação se completa, aproximadamente, aos 70 dias $^{26}$. Os incisivos são monorradiculados e apresentam rizogênese 
contínua durante toda a vida, para compensar o constante desgaste promovido pela sua função de roer; sua raiz é longa e curva para trás e o ápice fica localizado logo abaixo da região periapical do primeiro e do segundo molares. Sua exuberante base de implantação óssea permite a sua utilização como ancoragem para a movimentação do primeiro molar.

Para Martins-Ortiz ${ }^{53}$, 2004: a colocação de fios e molas nos molares exige habilidade para não lesar as papilas gengivais e sua permanência pelo tempo necessário não devem promover a instalação de doença periodontal. Ambas as situações comprometem direta ou indiretamente a análise dos efeitos da movimentação dentária induzida na crista óssea e região cervical das raízes, a ponto de afirmar-se que se houver sangramento durante a colocação dos aparelhos, algo deve ter acontecido de errado e o espécime deve ser descartado da amostra. Muitos trabalhos publicados apresentam resultados comprometidos por inflamação extensa da papila gengival e do ligamento periodontal com perda óssea distal ao primeiro molar, pela utilização de fios grossos, elásticos grandes, traumatismos na instalação do aparelho, por contaminação bacteriana, dieta inapropriadamente sólida e outros fatores.

A figura geométrica formada por planos tangenciais às faces mesial, vestibular, distal e lingual dos primeiros molares murinos mais os planos tangenciais dos seus ápices radiculares e de suas cúspides está representada por um trapézio. A ativação da mola com ancoragem no incisivo promove forças biologicamente aceitáveis na raiz mesial em suas áreas de pressão e tensão. Nas regiões cervicais e apicais da raiz mesial do primeiro molar murino, ocorrem os fenômenos celulares e teciduais em níveis desejáveis para que ocorra a movimentação dentária induzida com o mínimo dano estrutural e compativel com a normalidade das estruturas periodontais. Estas alterações podem assim ser estudadas em modelos experimentais para análises comparativas de variáveis propostas que possam interferir na movimentação dentária induzida.

$\mathrm{Na}$ raiz distal do primeiro molar murino, em função da forma trapezoidal deste 
dente, além das forças geradas pela mola, há uma rotação potencial do dente no alvéolo, principalmente da raiz distal, aumentando o efeito das forças nos tecidos periodontais. Dessa forma, na raiz distal de um mesmo molar tem-se a oportunidade de confirmar, comparativamente, os efeitos de variáveis sob condições de forças intensas biologicamente mais lesivas aos tecidos periodontais. Ao analisarmos os tecidos pulpares nesses dentes sob essas condições, podemos ter segurança de que as forças foram realmente efetivas e atuaram sobre aqueles tecidos pulpares.

Os molares murinos não apresentam rizogênese contínua e, essa característica, associada à morfologia radicular favorável, permite a extrapolação para humanos de resultados obtidos nesse modelo experimental de movimentação dentária induzida, considerando-se as limitações inerentes a qualquer metodologia e animal experimental. Apesar de sua dentição diferir da humana, por serem monofiodontes e seus incisivos apresentarem crescimento contínuo, os molares assemelham-se aos dos humanos, guardando as mesmas proporções de tamanho e outras peculiaridades anatômicas, que permitem seu uso nesses tipos de experimentos ${ }^{78,86}$, inclusive para estudos de efeitos pulpares.

O primeiro molar superior do rato apresenta cinco a seis raízes, sendo a mesiovestibular e a distovestibular ${ }^{35}$ as maiores e mais utilizadas nas análises microscópicas, devido à localização das raízes em planos diferentes, impossibilitando a obtenção de todas em um mesmo corte longitudinal.

Discutindo sobre o modelo experimental, Martins-Ortiz ${ }^{53}$ discorreu:

O rato apresenta-se como um animal experimental acessível e de fácil manuseio e sua manutenção é mais barata quando comparada com às dos primatas, gatos e cães. A utilização de ratos em experimentos com movimentação dentária induzida oferece algumas vantagens, como a facilidade de obtenção dos animais, devido ao curto tempo de procriação e às ninhadas com muitos filhotes, o que permite, também, um melhor controle genético, padronização do experimento, facilidade de repetições e 
amostras com grande número de animais com padronização da alimentação e a docilidade dos animais. Apesar do seu tamanho reduzido, possibilita condições adequadas para a instalação e manutenção do aparelho e a obtenção de quantidades representativas de tecidos para a inclusão e análise microscópica ${ }^{78,86}$.

Os molares dos ratos apresentam as maiores semelhanças com os dentes humanos. O ciclo completo de seu desenvolvimento processa-se aos 100 - 120 dias iniciais de vida dos animais. (Esses dentes sofrem desgaste muito lentamente, o que permite observações, mesmo na idade adulta, de alterações nos processos de desenvolvimento dentário). A formação do cemento secundário inicia-se em torno do $35^{\circ}$ dia, concomitantemente ao estresse funcional imposto aos dentes e, a partir daí, sua deposição torna-se constante durante toda a vida do rato, de modo que, na idade adulta, 1/3, ou mais, da raiz do dente é formado por cemento.

O primeiro molar superior apresenta cinco a seis raizes, sendo a mesiovestibular e a distovestibular as maiores e mais utilizadas nas análises microscópicas, devido à localização das raízes em planos diferentes, impossibilitando a obtenção de todas em um mesmo corte longitudinal. Os molares inferiores são pouco utilizados em pesquisas devido ao seu tamanho e às dificuldades que a mandibula oferece para a instalação de dispositivos ortodônticos. A região inter-radicular é ampla, havendo pouca deposição de cemento acelular no terço cervical ${ }^{86}$.

O osso alveolar murino apresenta poucos espaços medulares e maior densidade em relação ao osso alveolar humano. O tecido osteóide é abundante, com linhas de reversão relacionadas à periodicidade dos processos de remodelação óssea. As fibras de Sharpey estão presentes, com inclinação peculiar, nas regiões cervical e supra-alveolar, diferindo, apenas moderadamente, das observadas em dentes humanos.

No ligamento periodontal, os vasos sangüíneos, os fibroblastos e as células mesenquimais encontram-se proporcionalmente distribuidos, lembrando o periodonto humano, inclusive na largura entre o osso e o dente. Os restos epiteliais de Malassez en- 
contram-se presentes em número reduzido e caracteristicamente em forma de ilhotas.

No presente trabalho, utilizaramos ratos da linhagem Wistar (Rattus norvergicus). Um rato de 90 dias correspondente a um adulto jovem, já não existe mais crescimento e os animais encontram-se sexualmente maduros. A maturidade sexual desses animais ocorre em torno do $50^{\circ}$ e $60^{\circ}$ dia de vida. Recentes trabalhos indicam que $60 \%$ dos animais dessa linhagem atingem a maturidade sexual em torno do $30^{\circ}$ ao $50^{\circ}$ dia, no sexo feminino e entre o $18^{\circ}$ e o $31^{\circ}$ para $85 \%$ dos animais do sexo masculino. A menopausa acontece por volta do $450^{\circ}$ dia de vida ${ }^{78,86}$.

Para estudarmos a movimentação dentária induzida experimentalmente em ratos, devemos considerar a idade dos animais durante o experimento. A idade e o peso corporal mais utilizados na literatura correspondem a animais de 90 a 120 dias pe-

sando em média $350 g^{55,72,104,105}$. Características que equivalem à fase adulta jovem do homem, pois os ratos apresentam um periodo de vida médio de um ano e meio ${ }^{26}$. Nesse período, ocorre a completa formação das raízes dos molares.

\subsection{Sobre o modelo experimental: o aparelho}

No trabalho de Martins-Ortiz ${ }^{53}$, analisaram-se criteriosamente os aspectos metodológicos do aparelho utilizado, relatando suas vantagens e limitações.

O tipo de aparelho utilizado para a movimentação dentária induzida em ratos pode variar em alguns trabalhos, mas nos dias atuais predominam designs semelhantes aos utilizados neste trabalho. As variações principais estão relacionadas com o tipo de fio, a extensão da mola, a forma de fixação no molar e no incisivo. A padronização deve ser promovida em todos os trabalhos para evitar-se que influências decorrentes das variáveis estudadas sofram modificações conseqüentes de componentes não padronizados dos aparelhos.

Alguns trabalhos ${ }^{55,73,75,105,106,107}$ utilizaram o mesmo aparelho, mas com fios mais 
espessos, que promovem lesões na papila interdentária e favorecem a instalação de doença periodontal. As lesões na papila dentária e a doença periodontal concomitante interferem significantemente nos resultados dos trabalhos de movimentação dentária induzida em ratos. Como sugestão, na análise crítica de trabalhos sobre o assunto e na elaboração de trabalhos sobre o tema é sempre importante a apresentação de fotomicrografias, em aumento menor, que permitam a observação das estruturas periodontais vizinhas.

Outros modelos de aparelhos experimentais para a movimentação dentária induzida em ratos são parafusos expansores entre os primeiros molares superiores, molas promovendo a vestibularização dos primeiros molares superiores ${ }^{1,36,37}$ ou ainda a introdução de elastômeros entre o primeiro e o segundo molar superior ${ }^{41,42,109,113}$.

O modelo de aparelho, utilizando mola transversal ${ }^{1,41,42}$, atua tanto nos dentes quanto na sutura palatina sem uma determinação segura da proporção em que isso ocorre. Não é possível uma aferição da padronização dessas molas. A tábua óssea do rato é muito fina e limita o grau de observação microscópica, além de provocar deiscências.

Muitos trabalhos apresentam metodologias mal padronizadas, os aparelhos são instalados de forma muito aleatória. O modelo mais crítico é o de Waldo ${ }^{106}$, que preconiza a inserção de um elastômero entre o primeiro e o segundo molares superiores para induzir movimentação dentária. Essa forma de aplicação de força não permite a sua padronização ou quantificação exata, exercendo uma força não tão eficiente nem tão contínua, mas rapidamente dissipante, pois, atua sobre dois dentes, em vez de apenas um. Além disso, a força ainda é absorvida por uma considerável deflexão das cristas e septos ósseos de dois dentes, não apenas de um.

O modelo utilizando as molas transversais de vestibularização dos molares e a inserção de um elastômero entre os molares do rato não permitem uma quantificação exata das forças e, portanto, impedem uma padronização do modelo.

Em trabalhos anteriores, realizados na Disciplina de Patologia Bucal, utilizou- 
se uma mola de $6 \mathrm{~mm}$ distendendo-a $2 \mathrm{~mm}$ quando da ativação. No trabalho piloto dessa tese, percebeumos que a mola distendida em um comprimento total de $8 \mathrm{~mm}$, juntamente com as alças de dois a três helicóides nas extremidades, tornava-se um pouco grande para o espaço entre o primeiro molar superior esquerdo e o incisivo, dificultando a ativação em animais menores como nas fêmeas, por exemplo. Por isso, optou-se por uma nova medida da mola de 4mm, ativando-se $2 \mathrm{~mm}$ na instalação do aparelho e despendendo uma força de aproximadamente $75 c N^{39}$, no momento da ativação.

A utilização desse modelo como mola fechada permite a quantificação e a padronização das forças utilizadas nesse modelo experimental, conferindo maior credibilidade aos resultados obtidos.

\subsection{Sobre o modelo experimental: o tempo de observação e critérios de análise}

O tempo de observação dos efeitos periodontais das forças aplicadas na movimentação dentária induzida é fundamental para a consistência dos resultados obtidos. Pudemos verificar que, antes dos 3 dias, os efeitos periodontais são ainda iniciais e de difícil avaliação morfológica microscópica, provavelmente porque ainda estão ocorrendo no nível molecular e bioquímico, predominando, ainda, a ativação metabólica celular e a mobilização celular.

Aos 3 dias, podemos observar as áreas hialinas, as primeiras BMUs, a partir da verificação dos clastos multinucleados e as primeiras lacunas de Howship. Aos 5 dias, as áreas hialinas chegam à sua expressão morfológica máxima, as BMUs são numerosas e, se houver lesão da camada cementoblástica morfologicamente, ela pode ser detectamos. Nas áreas com hialinização segmentar do ligamento periodontal, detecta-se a reabsorção óssea a distância. Em alguns espécimes, pode ser detectada área de reabsorção dentária, ainda focal e inicial. Aos 7 dias, os fenômenos já estão em resolução; as áreas hialinas encontram-se em fagocitose com muitos macrófagos pre- 
sentes permeados a fibroblastos e outras células mesenquimais participantes do reparo periodontal. Os cementoblastos ainda estão ausentes e áreas mais extensas de reabsorção radicular podem ser detectadas. Na periferia da área periodontal, as BMUs são numerosas e presentes, caracterizando, classicamente, a reabsorção óssea a distância.

Esses períodos de tempos experimentais permitem avaliar o amplo espectro de fenômenos periodontais da movimentação dentária induzida que se estende do primeiro aos 7-10 dias, quando os tecidos periodontais tendem à normalidade. Após esse período, a mola perde sua ativação, não exercendo mais forças em decorrência da movimentação dentária obtida, e da erupção contínua do incisivo que, ao elevar a ancoragem para a margem incisal, diminui a força exercida.

A análise dos efeitos de forças antes dos três dias ou após sete dias, do ponto de vista microscópico óptico, não traz resultados comparativamente significantes entre as variáveis propostas a serem estudadas, pois, não abrangem os principais fenômenos teciduais e celulares da movimentação dentária induzida

\section{Dos resultados}

Os trabalhos mais bem fundamentados da literatura quanto à sua metodologia, design e critérios interpretativos indicam que a movimentação ortodôntica não induz alterações na polpa dentária tal como aumento do número de nódulos pulpares, metamorfose cálcica da polpa e envelhecimento precoce representado pela hialinização da matriz extracelular e fibrosamento. Essas alterações são genericamente denominadas de involutivas, regressivas ou degenerativas ${ }^{19,77}$.

Embora alguns trabalhos revelem aumento ${ }^{44}$, ou diminuição ${ }^{38,56}$ do fluxo sangüíneo, redução ${ }^{31,102}$ ou aumento ${ }^{46}$ do índice respiratório celular, aumento da angiogênese $\mathrm{e}^{20,21}$, mudança do nível local de certas enzimas e mediadores a partir de culturas e testes bioquímicos laboratoriais de tecido pulpar $^{76,110}$, esses resultados indicam possíveis mudanças nos níveis metabólicos do tecido pulpar e não sua inviabilidade biológica ou perda de vitalidade. 
Alguns estudos bioquímicos de amostras de tecidos pulpares de dentes movimentados ortodonticamente e outros trabalhos revelaram diminuição do nível metabólico respiratório, enquanto outros relataram aumento da circulação sangüínea mensurada, é inclusive da angiogênese. São resultados contraditórios e que podem ser atribuídos às limitações dos métodos utilizados, mas denotam que os efeitos pulpares da movimentação dentária são sutis e no nível bioquímico. Esses resultados, portanto, não permitem justificar pulpites e necrose pulpar associadas ao movimento ortodôntico.

O modelo experimental com animais como o utilizado neste trabalho permite eliminar variáveis. As disparidades na literatura sobre o tema e a fragilidade dos resultados apresentados, segundo Valladares Neto ${ }^{103}$ (2000), decorrem da interferência que alguns fatores exercem na comparação direta dos resultados encontrados entre as pesquisas publicadas, como exemplo:

$\checkmark \quad$ alguns dentes utilizados nas amostras são portadores de lesões traumáticas ${ }^{77}$;

$\checkmark \quad$ há graus diferentes de rizogênese ${ }^{11,12,19,31,62,96,97,102}$;

$\checkmark \quad$ as idades são diferentes entre os pacientes ${ }^{31,77,102}$;

$\checkmark \quad$ os diferentes modelos de animal utilizados ${ }^{80}$;

$\checkmark \quad$ as diferenças na direção $0^{3,58,61,96,97}$, na magnitude ${ }^{19,63,96,97}$ e na duração ${ }^{19,96,97}$ das forças aplicadas;

$\checkmark$ quantidade de movimentação dentária realizada ${ }^{111}$;

$\checkmark$ técnica e variação interprofissional no ato da exodontia das amostras;

$\checkmark \quad$ fixação dos espécimes ${ }^{96,97}$;

$\checkmark \quad$ método de avaliação ${ }^{19,29,30}$;

$\checkmark \quad$ ocorrência de artefatos de técnica erroneamente interpretados como efeito do tratamento ${ }^{62,63}$; 
$\checkmark$ equívocos na interpretação microscópica dos espécimes ${ }^{79,96}$;

$\checkmark \quad$ ausência de grupo controle $11,12,57,65,88$;

$\checkmark \quad$ variação de intervalo de tempo decorrido após a interrupção da força ${ }^{64}$;

$\checkmark$ ocorrência simultânea de achados independentes caracterizando uma associação ${ }^{88,92}$

$\checkmark \quad$ amostra insuficiente numericamente para exames estatísticos ${ }^{88}$;

$\checkmark \quad$ falta de averiguação pelo erro do método.

Outra dificuldade, encontrada na análise dos resultados da literatura pertinente, corresponde à falta de correlação clínica radiográfica com os achados microscópicos no diagnóstico das alterações pulpares ${ }^{14,23}$. A ausência de sensibilidade clínica não está relacionada, necessariamente, a um quadro microscópico de alteração pulpar.

Esses aspectos relevam a necessidade de estudos experimentais com variáveis controladas, pois, as imagens radiográficas de casuísticas são insensíveis a mudanças vasculares, celulares e moleculares que pudessem estar presentes nos eventos iniciais do envelhecimento pulpar, como a hialinização e os nódulos pulpares representam; apenas aparecem radiograficamente quando superiores a 200 micrometros ${ }^{14}$. Esses dados revelam que o exame radiográfico para verificar os efeitos pulpares do movimento ortodôntico não é o mais adequado. As calcificações pulpares em forma de nódulos e ou metamorfose cálcica não foram observados em nossos espécimes.

$\mathrm{Na}$ literatura, não há qualquer referência e citação da mais leve evidência de que a movimentação ortodôntica e outros tipos de movimento dentário em dentes normais possam, clinicamente ou experimentalmente, ter induzido envelhecimento precoce, pulpites e necrose pulpar

Em 2002, Mjör ${ }^{59}$, como se estivesse representando o pensamento coletivo da lite- 
ratura pertinente sobre os efeitos pulpares da movimentação ortodôntica, escreveu: As implicações para a Odontologia Restauradora das alterações pulpares após a intrusão ortodôntica ou qualquer outro movimento dentário são especulativas. Os designs experimentais para estudos pulpares associados com o movimento ortodôntico usam diferentes forças e tipos de movimentos em diferentes espécies e não chegam a conclusões substantivas. As evidências clínicas têm claramente demonstrado que o movimento ortodôntico não produz efeitos ruins na polpa e dentina ${ }^{59}$.

Em nossos resultados, a congestão vascular e estase observadas não foram consideradas, pois, são decorrentes dos procedimentos pré-operatórios. Da mesma forma, procedemos com a vacuolização odontoblástica e com a inclusão de núcleos no interior de túbulos dentinários.

Mesmos nos dentes com intensa reabsorção radicular indicando ação da força, os componentes do complexo dentinopulpar revelaram-se morfologicamente iguais em todos os grupos experimentais e períodos de observação de 1 a 7 dias. Em alguns dentes, a compressão periodontal era evidente também na região apical, mas os tecidos pulpares apresentavam-se tal como os dos dentes do grupo controle.

\section{Das implicações clínicas}

Para afirmarmos que "o dente está com necrose pulpar e foi provocada pelo movimento ortodôntico", devemos relembrar que nenhum caso foi publicado e devidamente explorado incluindo-se toda a documentação e discussão que elimine qualquer outra possibilidade etiológica. Esses casos deveriam apresentar a fotografia do dente, a radiografia periapical antes e durante o tratamento ortodôntico e descartar qualquer possibilidade de traumatismo dentário ${ }^{15}$.

Para o endodontista, o importante é diagnosticar com precisão e segurança o estado pulpar, no caso, a necrose pulpar ${ }^{15}$. Uma vez diagnosticada, o tratamento deve levar a um bom prognóstico. Prognosticar representa a arte de prever a evolução do 
tratamento instituído. Em dentes sem cárie, sem restaurações e sem doença periodontal, o traumatismo deve ser resgatado como principal suspeita de alterações pulpares, em especial, a necrose.

A necrose dos tecidos ocorre por dois mecanismos ${ }^{92}$. O primeiro, pela invasão bacteriana e ação com os neutrófilos com grande derramamento de enzimas proteolíticas e geração de pus; o tecido sofreu uma necrose por liquefação. O segundo mecanismo ocorre quando falta suprimento sangüíneo em tecidos pobres em enzimas proteolíticas, como a polpa dentária; as células perdem vitalidade, suas proteínas perdem água e coagulam, permanecendo na área por longos períodos. Esse segundo mecanismo representa a necrose por coagulação e ocorre na trombose, nos infartos e nos rompimentos dos vasos.

Os tecidos com necrose por coagulação não estão contaminados e os neutrófilos cedem lugar aos macrófagos que, lentamente, fagocitam na periferia. A polpa necrosada por coagulação está circunscrita pela dentina e em contato com o periodonto apenas pelo pequenino forame apical. Por meses e anos após o traumatismo, acumulam-se macrófagos e outros leucócitos ao redor do ápice, estabelecendo-se uma discreta pericementite crônica, e depois, um granuloma periapical. Essas duas situações clínicas são assintomáticas e descobertas em exames de rotina ou para documentação ortodôntica ${ }^{15}$.

O traumatismo dentário pode promover lesões severas, inclusive com fraturas alveolares e dentárias. Às vezes, há sangramento, avulsão, luxação, dor e muito desconforto, marcando a memória do paciente. O grau de gravidade das lesões e do desconforto está relacionado com a intensidade das forças no traumatismo, principalmente, com a sua concentração e distribuição ao longo da raiz e do osso. Muitas vezes, uma força, aparentemente severa, distribui-se por uma extensa região, lesa gengiva e tecidos moles, mas afeta muito pouco os dentes. Em outra situação, uma força pode não provocar dano aos tecidos gengivais e outros tecidos, mas, de forma concentrada, atua subitamente nos tecidos periapicais e rompe o feixe vascular, sem lesões visíveis 
clinicamente e sem sintomatologia. Nesse caso, o paciente não toma consciência da gravidade e não memoriza o fato. Em uma futura anamnese, não lembrará da cabeçada, da batida e do brinquedo, mas a polpa estará com necrose por coagulação. Apenas o escurecimento do dente ou uma eventual radiografia pode induzir ao diagnóstico.

A necrose pulpar induzida por traumatismo pode ser diagnosticada durante o tratamento ortodôntico. As alterações teciduais, próprias do movimento dentário, podem exacerbar os sinais clínicos e radiográficos da pericementite crônica e do granuloma periapical não diagnosticados na documentação ortodôntica inicial. Infelizmente, a maioria ainda analisa os dentes apenas pela radiografia panorâmica, sem radiografias periapicais.

Para Consolaro" ${ }^{17}$, em 2005, no "mundo das forças", as forças ortodônticas são muito pequenas, mesmo quando as chamamos de pesadas ou intensas. Em experimentos com intrusão experimental e movimentos dentários com forças muitíssimas intensas, não se conseguiu produzir necrose pulpar em um contexto similar ao tratamento ortodôntico.

Para identificar a causa, devemos resgatar o histórico do dente, as práticas esportivas, os acidentes, as brincadeiras, as férias e as radiografias anteriores ao tratamento; a causa deve ter sido um traumatismo. Se, mesmo assim, não identificarmos a causa, a falta de relatos criteriosos publicados e os dados experimentais recomendam que esses casos sejam considerados idiopáticos, um termo usado quando as causas são desconhecidas ou não identificadas. O movimento ortodôntico não tem magnitude de força suficiente para romper o feixe vascular apical, mesmo quando utilizamos força considerada excessiva. Nossas observações nesse experimento fundamentam essas afirmações. Para ocorrer essa ruptura vascular, devemos encontrar duas características: grande e rápido deslocamento dentário e forças intensas e bruscas ${ }^{17}$. Essas duas características são típicas do traumatismo e não do movimento ortodôntico.

Considerando que a literatura não apresenta evidência quer seja clínica, radio- 
gráfica e/ou experimental, em 2002, Consolaro ${ }^{16}$ explicou por que afirmara que o tratamento ortodôntico não promove alterações pulpares.

O dente está ligado ao osso pelas fibras do ligamento periodontal. Entre as fibras estão os fibroblastos, vasos, nervos e a parte geleificada da matriz extracelular. Os cementoblastos e osteoblastos estão nas superfícies radiculares e ósseas. O deslocamento dentário induzido por forças ortodônticas se faz principalmente a custas da compressão do ligamento periodontal sobre a superfície óssea alveolar nas áreas de pressão. Também ocorre certo grau de movimentação por uma deformação da crista óssea alveolar que cede um pouco na porção cervical, contribuindo para o deslocamento dentário. Essa capacidade pode ser denominada de deflexão óssea.

Nos movimentos de inclinação, por maior que seja a força ortodôntica, o máximo de movimento dentário conseguido está limitado pela espessura do espaço periodontal, isso se conseguirmos comprimir totalmente o ligamento. Na região apical, dificilmente, poderemos atribuir parte do deslocamento dentário à deflexão, pois, a massa óssea é maior e não deformável como a crista alveolar. O espaço ocupado pelo ligamento periodontal nos dentes humanos tem 200 a 400 micrometros, em média, 250 micrometros ou 0,25mm. Numa régua, veremos que esse espaço é muito fino. Ao percebermos a real dimensão do espaço, entenderemos por que as forças ortodônticas são realmente diminutas; precisamos de pouca intensidade para deslocar o dente nesses $0,25 \mathrm{~mm}$ periodontais.

O suprimento sangüineo e a inervação da polpa se fazem por nervos e vasos que, advindos do osso, atravessam o ligamento e adentram pelo forame apical. Os tecidos moles são distensíveis e suportam deslocamentos consideráveis, como observamos ao esticá-los nos braços e na face. Um deslocamento de 0,25mm no ligamento periodontal apical não é suficiente para romper os vasos e nervos que se direcionam para a polpa.

Traumatismos com forças súbitas e fortemente aplicadas nos tecidos moles rompem os vasos e provocam hemorragias. No ligamento periodontal, deslocamentos 
bruscos e fortes, com ou sem luxação e avulsão dentária, tendem a promover rompimento dos vasos e nervos e conseqüente necrose pulpar.

Para Consolaro ${ }^{16}$ (2002), a principal referência na afirmação de que o tratamento ortodôntico não provoca necrose pulpar está nas dimensões anatômicas da região apical, que limitam a extensão do movimento dentário, e nas características das forças ortodônticas necessárias, mesmo quando intensas. As forças ortodônticas têm uma ação mais lenta e menos intensa do que as forças geradas nos procedimentos de separação dentária durante os preparos cavitários e procedimentos protéticos nas faces proximais; nem por isso eles provocam necrose pulpar. Para ele, o traumatismo é a principal causa da necrose pulpar em dentes hígidos e descoberta durante o tratamento ortodôntico. 
Conchusão 


\section{Conclusão}

A partir dos resultados obtidos e relevando as limitações inerentes ao modelo experimental aplicado, podemos concluir que a movimentação dentária induzida não promove alterações morfológicas, na polpa dentária, detectáveis na microscopia óptica, quer sejam de natureza degenerativa, quer sejam de natureza inflamatória. 


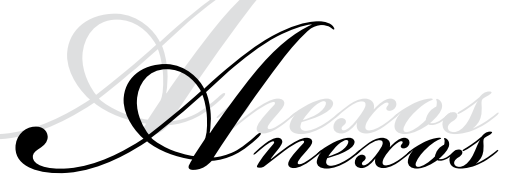




\section{Anexos}

\section{Testes referentes às análises pulpares}

Teste não paramétrico de Kruskal Wallis

Arquivo: F:\ESTATISTICA_RENATA ICONGESTAO VASCULAR.DBF Variável independente: CONTROLE/ S.MDI, Variável dependente: N2

\begin{tabular}{lccccc}
\multicolumn{1}{c}{ Grupo } & Mediana & \multicolumn{2}{c}{ Soma de postos } & Posto médio & N. de valores \\
3 dias de MDI & 1.00000000 & 143.000000 & 15.8888888 & 9 & \\
5 dias de MDI & 1.00000000 & 180.000000 & 20.0000000 & 9 \\
7 dias de MDI & 1.00000000 & 180.000000 & $20.000-0000$ & 9 \\
controle/ S.MDI & 1.00000000 & 200.000000 & 20.0000000 & 10
\end{tabular}

$\mathrm{Hc}=6.400000$

Quiquadrado com 3 graus de liberdade Probabilidade $=0.093690$

Teste de Dunn para comparações individuais

Nível de significância $=0.05$

\begin{tabular}{|c|c|c|c|}
\hline Comparação & - & Valor crítico & Interpretação \\
\hline & - & & \\
\hline 3 dias de MDIX 5 dias de MDI & -4.1111111 & 13.4620778 & Não signific. \\
\hline 3 dias de MDIX 7 dias de MDI & -4.1111111 & 13.4620778 & Não signific. \\
\hline 3 dias de MDIX controle/ S.MDI & -4.1111111 & 13.1212104 & Não signific. \\
\hline 5 dias de MDIX 7 dias de MDI & 0.00000000 & 13.4620778 & Não signific. \\
\hline 5 dias de MDIX controle/ S.MDI & 0.00000000 & 13.1212104 & Não signific. \\
\hline 7 dias de MDIX controle/ S.MDI & 0.00000000 & 13.1212104 & Não signific. \\
\hline
\end{tabular}

Teste de Dunn para comparações individuais

Nível de significância $=0.01$

\begin{tabular}{|c|c|c|c|}
\hline Comparação & Diferença & Valor crítico & Interpretação \\
\hline 3 dias de MDIX 5 dias de MDI & -4.1111111 & 16.0424836 & Não signific. \\
\hline 3 dias de MDIX 7 dias de MDI & -4.1111111 & 16.0424836 & Não signific. \\
\hline 3 dias de MDIX controle/ S.MDI & -4.1111111 & 15.6362789 & Não signific. \\
\hline 5 dias de MDIX 7 dias de MDI & 0.00000000 & 16.0424836 & Não signific. \\
\hline 5 dias de MDIX controle/ S.MDI & 0.00000000 & 15.6362789 & Não signific. \\
\hline 7 dias de MDIX controle/ S.MDI & 0.00000000 & 15.6362789 & Não signific. \\
\hline
\end{tabular}


Teste não paramétrico de Kruskal Wallis

Arquivo: F:IESTATISTICA_RENATA\NODULOS_PULPARES.DBF

Variável independente: CONTROLE/ S.MDI, Variável dependente: N2

\begin{tabular}{lcccc}
\multicolumn{1}{c}{ Grupo } & Mediana & Soma de postos & Posto médio & N. de valores \\
\hline 3 dias de MDI & 0.00000000 & 166.500000 & 18.5000000 & 9 \\
5 dias de MDI & 0.00000000 & 166.500000 & 18.5000000 & 9 \\
7 dias de MDI & 0.00000000 & 166.500000 & 18.5000000 & 9 \\
controle/ S.MDI & 0.00000000 & 203.500000 & 20.3500000 & 10
\end{tabular}

$\mathrm{Hc}=2.700000$

Quiquadrado com 3 graus de liberdade Probabilidade $=0.440227$

Teste de Dunn para comparações individuais

Nível de significância $=0.05$

\begin{tabular}{lccl} 
Comparação & Diferença & Valor crítico & Interpretação \\
\hline 3 dias de MDIX 5 dias de MDI & 0.00000000 & 13.4620778 & Não signific. \\
3 dias de MDIX 7 dias de MDI & 0.00000000 & 13.4620778 & Não signific. \\
3 dias de MDIX controle/ S.MDI & -1.8500000 & 13.1212104 & Não signific. \\
5 dias de MDIX 7 dias de MDI & 0.00000000 & 13.4620778 & Não signific. \\
5 dias de MDIX controle/ S.MDI & -1.8500000 & 13.1212104 & Não signific. \\
7 dias de MDIX controle/ S.MDI & -1.8500000 & 13.1212104 & Não signific.
\end{tabular}

Teste de Dunn para comparações individuais

Nível de significância $=0.01$

\begin{tabular}{llll} 
Comparação & Diferença & Valor crítico & Interpretação \\
\hline 3 dias de MDIX 5 dias de MDI & 0.00000000 & 16.0424836 & Não signific. \\
3 dias de MDIX 7 dias de MDI & 0.00000000 & 16.0424836 & Não signific. \\
3 dias de MDIX controle/ S.MDI & -1.8500000 & 15.6362789 & Não signific. \\
5 dias de MDIX 7 dias de MDI & 0.00000000 & 16.0424836 & Não signific. \\
5 dias de MDIX controle/ S.MDI & -1.8500000 & 15.6362789 & Não signific. \\
7 dias de MDIX controle/ S.MDI & -1.8500000 & 15.6362789 & Não signific. \\
\hline
\end{tabular}


Teste não paramétrico de Kruskal Wallis

Arquivo: F:IESTATISTICA_RENATAIVACUOLIZACAO CELULAR.DBF

Variável independente: CONTROLE/ S.MDI Variável dependente: N2

\begin{tabular}{lllll} 
Grupo & Mediana & Soma de postos & Posto médio & N. de valores \\
\hline 3 dias de MDI & 0.00000000 & 176.000000 & 19.5555555 & 9 \\
5 dias de MDI & 0.00000000 & 157.500000 & 17.5000000 & 9 \\
7 dias de MDI & 0.00000000 & 157.500000 & 17.5000000 & 9 \\
controle/ S.MDI & 0.00000000 & 212.000000 & 21.2000000 & 10
\end{tabular}

$\mathrm{Hc}=3.498039$

Quiquadrado com 3 graus de liberdade Probabilidade $=0.321016$

Teste de Dunn para comparações individuais

Nível de significância $=0.05$

\begin{tabular}{lccl} 
Comparação & Diferença & Valor crítico & Interpretação \\
\hline 3 dias de MDIX 5 dias de MDI & 2.05555556 & 13.4620778 & Não signific. \\
3 dias de MDIX 7 dias de MDI & 2.05555556 & 13.4620778 & Não signific. \\
3 dias de MDIX controle/ S.MDI & -1.6444444 & 13.1212104 & Não signific. \\
5 dias de MDIX 7 dias de MDI & 0.00000000 & 13.4620778 & Não signific. \\
5 dias de MDIX controle/ S.MDI & -3.7000000 & 13.1212104 & Não signific. \\
7 dias de MDIX controle/ S.MDI & -3.7000000 & 13.1212104 & Não signific.
\end{tabular}

Teste de Dunn para comparações individuais

Nível de significância $=0.01$

\begin{tabular}{lccl}
\multicolumn{1}{c}{ Comparação } & Diferença & Valor crítico & Interpretação \\
\hline 3 dias de MDIX 5 dias de MDI & 2.05555556 & 16.0424836 & Não signific. \\
3 dias de MDIX 7 dias de MDI & 2.05555556 & 16.0424836 & Não signific. \\
3 dias de MDIX controle/ S.MDI & -1.6444444 & 15.6362789 & Não signific. \\
5 dias de MDIX 7 dias de MDI & 0.00000000 & 16.0424836 & Não signific. \\
5 dias de MDIX controle/ S.MDI & -3.7000000 & 15.6362789 & Não signific. \\
7 dias de MDIX controle/ S.MDI & -3.7000000 & 15.6362789 & Não signific.
\end{tabular}




\section{Testes referentes as análises periodontais}

Teste não paramétrico de Kruskal Wallis

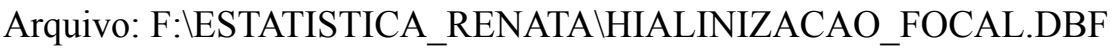
Variável independente: CONTROLE/ S.MDI, Variável dependente: N2

\begin{tabular}{lllll} 
Grupo & Mediana & Soma de postos & Posto médio & N. de valores \\
\hline 3 dias de MDI & 0.00000000 & 176.500000 & 19.6111111 & 9 \\
5 dias de MDI & 0.00000000 & 176.500000 & 19.6111111 & 9 \\
7 dias de MDI & 0.00000000 & 195.000000 & 21.6666666 & 9 \\
controle/ S.MDI & 0.00000000 & 155.000000 & 15.5000000 & 10
\end{tabular}

$\mathrm{Hc}=3.580952$

Quiquadrado com 3 graus de liberdade Probabilidade $=0.310413$

Teste de Dunn para comparações individuais

Nível de significância $=0.05$

\begin{tabular}{lccl} 
Comparação & Diferença & Valor crítico & \multicolumn{1}{c}{ Interpretação } \\
\hline 3 dias de MDIX 5 dias de MDI & 0.00000000 & 13.4620778 & Não signific. \\
3 dias de MDIX 7 dias de MDI & -2.0555555 & 13.4620778 & Não signific. \\
3 dias de MDIX controle/ S.MDI & 4.11111111 & 13.1212104 & Não signific. \\
5 dias de MDIX 7 dias de MDI & -2.0555555 & 13.4620778 & Não signific. \\
5 dias de MDIX controle/ S.MDI & 4.11111111 & 13.1212104 & Não signific. \\
7 dias de MDIX controle/ S.MDI & 6.16666667 & 13.1212104 & Não signific.
\end{tabular}

Teste de Dunn para comparações individuais

Nível de significância $=0.01$

\begin{tabular}{llcl} 
Comparação & Diferença & Valor crítico & Interpretação \\
\hline 3 dias de MDIX 5 dias de MDI & 0.00000000 & 16.0424836 & Não signific. \\
3 dias de MDIX 7 dias de MDI & -2.0555555 & 16.0424836 & Não signific. \\
3 dias de MDIX controle/ S.MDI & 4.11111111 & 15.6362789 & Não signific. \\
5 dias de MDIX 7 dias de MDI & -2.0555555 & 16.0424836 & Não signific. \\
5 dias de MDIX controle/ S.MDI & 4.11111111 & 15.6362789 & Não signific. \\
7 dias de MDIX controle/ S.MDI & 6.16666667 & 15.6362789 & Não signific.
\end{tabular}


Teste não paramétrico de Kruskal Wallis Arquivo: F:IESTATISTICA_RENATAUHIALINIZACAO_SEGMENTAR.DBF Variável independente: CONTROLE/ S.MDI , Variável dependente: N2

\begin{tabular}{lcccc} 
Grupo & Mediana & Soma de postos & Posto médio & N. de valores \\
\hline 3 dias de MDI & 1.00000000 & 210.500000 & 23.3888888 & 9 \\
5 dias de MDI & 1.00000000 & 210.500000 & 23.3888888 & 9 \\
7 dias de MDI & 1.00000000 & 192.000000 & 21.3333333 & 9 \\
controle/ S.MDI & 0.00000000 & 90.0000000 & 9.00000000 & 10
\end{tabular}

$\mathrm{Hc}=15.97647$

Quiquadrado com 3 graus de liberdade Probabilidade $=\mathbf{0 . 0 0 1 1 4 6}$

Teste de Dunn para comparações individuais

Nível de significância $=0.05$

\begin{tabular}{lcll}
\multicolumn{1}{c}{ Comparação } & Diferença & Valor crítico & Interpretação \\
\hline 3 dias de MDIX 5 dias de MDI & 0.00000000 & 13.4620778 & Não signific. \\
3 dias de MDIX 7 dias de MDI & 2.05555556 & 13.4620778 & Não signific. \\
3 dias de MDIX controle/ S.MDI & 14.3888888 & 13.1212104 & signific./entre 3 dias de MDI e controle \\
5 dias de MDIX 7 dias de MDI & 2.05555556 & 13.4620778 & Não signific. \\
5 dias de MDIX controle/ S.MDI & 14.3888888 & 13.1212104 & signific./entre 5 dias de MDI e controle \\
7 dias de MDIX controle/ S.MDI & 12.3333333 & 13.1212104 & Não signific.
\end{tabular}

Teste não paramétrico de Kruskal Wallis

Arquivo: F:IESTATISTICA_RENATA \REABSORCAO_FRONTAL.DBF

Variável independente: CONTROLE/ S.MDI Variável dependente: N2

\begin{tabular}{lcccc} 
Grupo & Mediana & Soma de postos & Posto médio & N. de valores \\
\hline 3 dias de MDI & 0.00000000 & 190.500000 & 21.1666666 & 9 \\
5 dias de MDI & 0.00000000 & 172.000000 & 19.111111 & 9 \\
7 dias de MDI & 0.00000000 & 190.500000 & 21.1666666 & 9 \\
controle/ S.MDI & 0.00000000 & 150.000000 & 15.0000000 & 10
\end{tabular}

$\mathrm{Hc}=4.103448$

Quiquadrado com 3 graus de liberdade Probabilidade $=0.250508$ 
Teste de Dunn para comparações individuais

Nível de significância $=0.05$

\begin{tabular}{lccc}
\multicolumn{1}{c}{ Comparação } & Diferença & Valor crítico & Interpretação \\
\hline 3 dias de MDIX 5 dias de MDI & 2.05555556 & 13.4620778 & Não signific. \\
3 dias de MDIX 7 dias de MDI & 0.00000000 & 13.4620778 & Não signific. \\
3 dias de MDIX controle/ S.MDI & 6.16666667 & 13.1212104 & Não signific. \\
5 dias de MDIX 7 dias de MDI & -2.0555555 & 13.4620778 & Não signific. \\
5 dias de MDIX controle/ S.MDI & 4.11111111 & 13.1212104 & Não signific. \\
7 dias de MDIX controle/ S.MDI & 6.16666667 & 13.1212104 & Não signific.
\end{tabular}

Teste não paramétrico de Kruskal Wallis

Arquivo: F:IESTATISTICA RENATA $\backslash$ REABSORCAO DISTANCIA.DBF

Variável independente: CONTROLE/ S.MDI, Variável dependente: N2

\begin{tabular}{lcccc} 
Grupo & Mediana & Soma de postos & Posto médio & N. de valores \\
\hline 3 dias de MDI & 1.00000000 & 196.500000 & 21.8333333 & 9 \\
5 dias de MDI & 1.00000000 & 215.000000 & 23.8888888 & 9 \\
7 dias de MDI & 1.00000000 & 196.500000 & 21.8333333 & 9 \\
controle/ S.MDI & 0.00000000 & 95.0000000 & 9.50000000 & 10
\end{tabular}

$\mathrm{Hc}=14.36257$ Quiquadrado com 3 graus de liberdade $\quad$ Probabilidade $=\mathbf{0 . 0 0 2 4 5 0}$

Teste de Dunn para comparações individuais

Nível de significância $=0.10$ significante entre todos os dias e o controle

\begin{tabular}{llll}
\multicolumn{1}{c}{ Comparação } & Diferença & Valor crítico & Interpretação \\
\hline 3 dias de MDIX 5 dias de MDI & -2.0555555 & 12.2154961 & Não signific. \\
3 dias de MDIX 7 dias de MDI & 0.00000000 & 12.2154961 & Não signific. \\
3 dias de MDIX controle/ S.MDI & 2.3333333 & 11.9061929 & signific,/entre 3 dias de MDI e o controle \\
5 dias de MDIX 7 dias de MDI & 2.05555556 & 12.2154961 & Não signific. \\
5 dias de MDIX controle/ S.MDI & 14.3888888 & 11.9061929 & signific./entre 5 dias de MDI e o controle \\
7 dias de MDIX controle/ S.MDI & 12.3333333 & 11.9061929 & signific./entre 7 dias de MDI e o controle
\end{tabular}


Teste de Dunn para comparações individuais Nível de significância $=0.05$

\begin{tabular}{lcll}
\multicolumn{1}{c}{ Comparação } & Diferença & Valor crítico & Interpretação \\
\hline 3 dias de MDIX 5 dias de MDI & -2.0555555 & 13.4620778 & Não signific. \\
3 dias de MDIX 7 dias de MDI & 0.00000000 & 13.4620778 & Não signific. \\
3 dias de MDIX controle/ S.MDI & 12.3333333 & 13.1212104 & Não signific. \\
5 dias de MDIX 7 dias de MDI & 2.05555556 & 13.4620778 & Não signific. \\
5 dias de MDIX controle/ S.MDI & 14.3888888 & 13.1212104 & signific./entre 5 dias de MDI e o controle \\
7 dias de MDIX controle/ S.MDI & 12.3333333 & 13.1212104 & Não signific.
\end{tabular}

Teste não paramétrico de Kruskal Wallis Arquivo: F:IESTATISTICA_RENATA \REABSORCAO_RADICULAR.DBF Variável independente: CONTROLE/ S.MDI, Variável dependente: N2

\begin{tabular}{lcccc} 
Grupo & Mediana & Soma de postos & Posto médio & N. de valores \\
\hline 3 dias de MDI & 0.00000000 & 94.5000000 & 10.5000000 & 9 \\
5 dias de MDI & 1.00000000 & 242.500000 & 26.9444444 & 9 \\
7 dias de MDI & 1.00000000 & 261.000000 & 29.0000000 & 9 \\
controle/ S.MDI & 0.00000000 & 105.000000 & 10.5000000 & 10
\end{tabular}

$\mathrm{Hc}=32.51764$

Quiquadrado com 3 graus de liberdade $\quad$ Probabilidade $=\mathbf{0 . 0 0 0 0 0 0}$

Teste de Dunn para comparações individuais

Nível de significância $=0.05$

\begin{tabular}{lcll} 
Comparação & Diferença & Valor crítico & \multicolumn{1}{c}{ Interpretação } \\
\hline 3 dias de MDIX 5 dias de MDI & -16.444444 & 13.4620778 & signific./entre 3 e 5 dias de MDI \\
3 dias de MDIX 7 dias de MDI & -18.500000 & 13.4620778 & signific./entre 3 e 7 dias de MDI \\
3 dias de MDIX controle/ S.MDI & 0.00000000 & 13.1212104 & Não signific. \\
5 dias de MDIX 7 dias de MDI & -2.0555555 & 13.4620778 & Não signific. \\
5 dias de MDIX controle/ S.MDI & 16.4444444 & 13.1212104 & signific./entre 5 dias de MDI e o controle \\
7 dias de MDIX controle/ S.MDI & 18.5000000 & 13.1212104 & signific./entre 7 dias de MDI e o controle
\end{tabular}


Teste de Dunn para comparações individuais

Nível de significância $=0.01$

\begin{tabular}{lcll} 
Comparação & Diferença & Valor crítico & \multicolumn{1}{c}{ Interpretação } \\
\hline 3 dias de MDIX 5 dias de MDI & -16.444444 & 16.0424836 & signific./entre 3 e 5 dias de MDI \\
3 dias de MDIX 7 dias de MDI & -18.500000 & 16.0424836 & signific./entre 3 e 7 dias de MDI \\
3 dias de MDIX controle/ S.MDI & 0.00000000 & 15.6362789 & Não signific. \\
5 dias de MDIX 7 dias de MDI & -2.0555555 & 16.0424836 & Não signific. \\
5 dias de MDIX controle/ S.MDI & 16.4444444 & 15.6362789 & signific./entre 5 dias de MDI e o controle \\
7 dias de MDIX controle/ S.MDI & 18.5000000 & 15.6362789 & signific./entre 7 dias de MDI e o controle
\end{tabular}




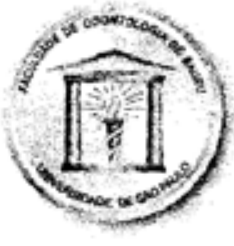

Of. $n^{\circ}$ CEEPA 06/2004

\section{Universidade de São Paulo}

\section{Faculdade de Odontologia de Bauru}

Al. Dr. Octávio Pinheiro Brisolla, 9-75 - Bauru-SP - CEP 17012-901 - C.P. 73

PABX (0XX14)3235-8000 - FAX (0XX14)3223-4679

Comissão de Ética no Ensino e Pesquisa em Animais

Bauru, 05 de novembro de 2004.

Senhor Professor,

Em atenção a sua consulta referente à pesquisa desenvolvida sob sua orientação, intitulada "Influência dos bisfosfonatos na movimentação induzida, na freqüência $e$ nas dimensões das reabsorçōes radiculares associadas", de autoria da C.D. Maria Fernanda Martins-Ortiz, tendo em vista seu início ser anterior à constituição desta Comissão, informamos que, não cabe, no momento, a análise ética da referida pesquisa.

Sendo o que nos apresenta para o momento, despedimo-nos,

Atenciosamente,

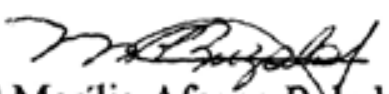

Prof $\mathrm{Dr}^{\mathrm{a}}$ Marilia Afonso Rábelo Buzalaf

Presidente da Comissão de Ética no Ensino e Pesquisa em Animais 


\section{Unesp UNIVERSIDADE ESTADUAL PAULISTA \\ "CÂMPUS" DE ARAÇATUBA - FACULDADE DE ODONTOLOGIA \\ CURSOS DE ODONTOLOGIA E DE MEDICINA VETERINÁRIA}

\section{COMISSÃO DE ÉTICA NA EXPERIMENTAÇÃO ANIMAL (CEEA)}

\section{CERTIFICADO}

Certificamos que o Projeto "Determinação do perfil morfológico da movimentação dentária induzida em ratos de 1 a 7 dias", sob a responsabilidade do PROF. DR. ALBERTO CONSOLARO e MARIA FERNANDA MATINSORTIZ / TÂNIA REGINA GRÃO VELLOSO está de acordo com os Principios Éticos na Experimentação Animal adotado pelo Colégio Brasileiro de Experimentação Animal (COBEA) e foi aprovado pela CEEA em reunião de 11/06/2002.

Araçatuba, 12 de junho de 2002.

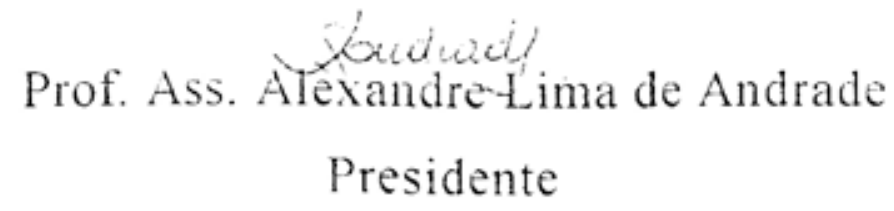




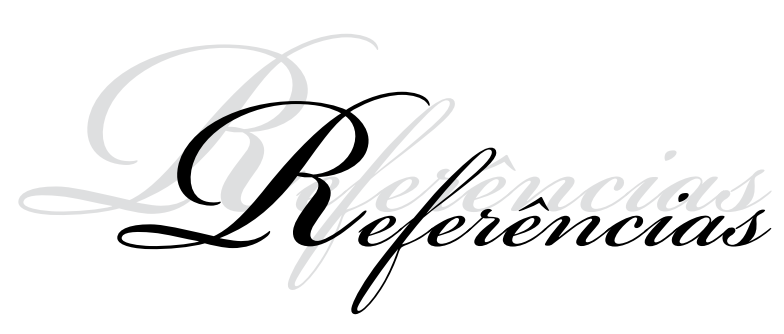




\section{Referências}

1. ADACHI, H. et al. Effects of topical administration of a bisphosphonate (risedronate) on orthodontic tooth movements in rats. J. Dent. Res., 1994 Aug;73(8):1478-86.

2. ALATLI-KUT, I.; HULTENBY, K.; HAMMARSTROM, L. Disturbances of cementum formation induced by single injection of 1-hydroxyethylidene-1,1-bisphosphonate (HEBP) in rats: light and scanning electron microscopic studies. Scand. J. Dent. Res., v.102, n.5, p.260-8. Oct. 1994.

3. ANSTENDIG, H.S.; KRONMAN, J.H. A histologic study of pulpal reaction to orthodontic tooth movement in dogs. Angle Orthod., v.42, n.1, p.50-5, Jan. 1972.

4. ASHCRAFT, M.B.; SOUTHARD, K.A.; TOLLEY, E.A. The effect of corticosteroid-induced osteoporosis on orthodontic tooth movement. Am. J. Orthod. Dentofacial Orthop., v.102, n.4, p.310-9, Oct. 1992

5. BARWICK, P.J.; RAMSAY, D.S. Effect of brief intrusive force on human pulpal blood flow. Am. J. Orthod. Dentofacial Orthop., v.110, n.3, p.273-9, Sept. 1996.

6. BAUSS, O.; SCHWESTKA-POLLY, R.; KILIARIDIS, S. Influence of orthodontic derotation and extrusion on pulpal and periodontal condition of autotransplanted immature third molars. Am. J. Orthod. Dentofacial Orthop., v.125, n.4, p.488-96, Apr. 2004.

7. BENDER, I. B.; BYERS, M. R.; MORI, K. Periapical replacement resorption of permanent, vital, endodontically treated incisors after orthodontic movement: report of two cases. J. Endod., v.23, n.12, p.768-73, Dec. 1997.

8. BRÄNNSTRÖN, M. Dentinal and pulpal reactions: physio-pathological aspects of dentinal and pulpal response to irritants. Periódico não identificado, p.231-46, 1967.

9. BRIDGES. T.; KING, G.; MOHAMMED, A. The effect of age on tooth movement and mineral density in the alveolar tissues of the rat. Am. J. Orthod. Dentofacial Orthop., v.93, n.3, p.24550, Mar. 1988.

10. BUNNER, M.; JOHNSEN, D. Quantitative assessment of intrapulpal axon response to orthodontic movement. Am. J. Orthod., v.82, n.3, p.244-50, Sept. 1982.

11. BUTCHER, E.O.; TAYLOR, A.C. The vascularity of the incisor pulp of the monkey and its alteration by tooth retraction. J. Dent. Res., v.31, n.2, p.239-47, Apr. 1952.

12. BUTCHER, E.O.; TAYLOR. A.C. The effects of denervation and ischemia upon the teeth of the monkey. J. Dent. Res., v.30, n.2, p.265-75, Apr. 1951.

13. CONSOLARO, A. Ácidos e sistemas adesivos sobre a polpa dentária: uma abordagem crítica. RBO, v.54, n.4, p.198-203, jul./ago. 1997.

14. CONSOLARO, A. Alterações pulpares: correlações clínico-radiográficas e microscópicas. In: LEONARDO, M. R.; LEAL, J.M. Endodontia: tratamento de canais radiculares. 3ed. São Paulo, Editorial Médica Panamericana, 1998. Cap.3, p.41-61.

15. CONSOlARO, A. Movimento ortodôntico não promove necrose pulpar. R. Clin. Ortodon. Dental Press, v.1, n.4, p.99-100, Aug.-Set. 2002. 
16. CONSOLARO, A. Ortodontia não induz necrose pulpar: qual a referência? R. Clin. Ortodon. Dental Press, v.1, n.5, p. 100, Out.-Nov. 2002.

17. CONSOLARO, A. Reabsorções dentárias nas especialidades clínicas. 2ed. Maringá, Dental Press, 2005

18. CUOGHI, O. A. Avaliação macro e microscópica dos primeiros momentos da movimentação dentária induzida em macacos da espécie Cebus apella. Bauru, 1997. 138p. Tese (Doutorado) - Faculdade de Odontologia de Bauru, Universidade de São Paulo.

19. DELIVANIS, H.P.; SAUER, G.J. Incidence of canal calcification in the orthodontic patient. Am. J. Orthod., v.82, n.1, p.58-61, July 1982.

20. DERRINGER, K.A.; JAGGERS, D.C.; LINDEN, R.W. Angiogenesis in human dental pulp following orthodontic tooth movement. J. Dent. Res., v.75, n.10, p.1761-6, Oct. 1996.

21. DERRINGER, K.A.; LINDEN, R.W. Enhanced angiogenesis induced by diffusible angiogenic growth factors released from human dental pulp explants of orthodontically moved teeth. Eur. J. Orthod., v.20, n.4, p.357-67, Aug. 1998.

22. ENGSTROM, C. Root resorptions during orthodontic tooth movement and boné remodelling dynamics during hypocalcaemia and treatment with biphosphonate. In: DAVIDOVITCH, Z. The biological mechanisms of tooth eruption and root resorpition. EBSCO Media, Birmingham, p.391-7, 1988.

23. ESTRELA, C.; FIGUEIREDO, J. A. C. Endodontia: princípios biológicos e mecânicos. São Paulo, Artes Médicas, 1999.

24. FANIBUNDA, K.B. A preliminary study of the volume of the pulp in the permanent human teeth. Personal Comunication., 1975 apud AVERY, J.K. Polpa. In: BHASKAR, S.N. Histologia e embriologia oral de Orban. 8.ed. São Paulo, Artes Médicas, 1978. P.143-81.

25. FANIBUNDA, K.B. Volume of the dental pulp cavity-method of measurement. J. dent. Res., v.52, n.5, p.971, Apr. 1973.

26. FARRIS, E. J. Breeding of the rat. In: York, Hafner Publishing, 1963. Cap.1, p.1-18

The rat in laboratory investigation. 2ed. New

27. FISCHER, G. Beiträge zur Biologie der zahnpulpa Berlin, Berlinische Verlagsanstalt, 1933 apud STENVIK, A.; MJÖR, I. A. Pulp and dentine reactions to experimental tooth intrusion. A histologic study of the initial changes. Am. J. Orthod., v.57, n.4, p.370-85, Apr. 1970.

28. FREIRE, A.; TANCREDO, N. Implicações pulpares na movimentação ortodôntica. Rev. Bras. Odontol., v.36, n.3, p.56-64, maio/jun. 1979.

29. GUEVARA, M.J.; MCCLUGAGE, S.G.Jr. Effects of intrusive forces upon the microvasculature of the dental pulp. Angle Orthod., v.50, n.2, p.129-34, Apr. 1980.

30. HALL, C.J.; FREER, T.J. The effects of early orthodontic force application on pulp test responses. Aust. Dent. J.,v.43, n.5, p.359-61, Oct. 1998.

31. HAMERSKY, P.A.; WEIMER, A.D.; TAINTOR, J.F. The effect of orthodontic force application on the pulpal tissue respiration rate in the human premolar. Am. J. Orthod., v.77, n.4, p.368-78, Apr. 1980. 
32. HAMILTON, R.S.; GUTMANN, J.L. Endodontic-orthodontic relationships: a review of integrated treatment planning challenges. Int. Endod. J., v.32, n.5, p.343-60, Sept. 1999.

33. HELLER, I.J.; NANDA, R. Effect of metabolic alteration of periodontal fibers on orthodontic tooth movement. An experimental study. Am. J. Orthod., v.75, n.3, p.239-58, Mar. 1979.

34. HOUSTON, W. J. A new design of rat mouth prop. J. Dent. Res., v.43, p.458, May-June 1964.

35. HYVONEN, P. M.; HANHIJARVI, H. The effect of clodronate (dichloromethylene bisphosphonate) on fluoride kinetics during a 30-day treatment in the rat. Proc. Finn. Dent. Soc., v.85, n.6, p.429-33, 1989.

36. IGARASHI, K. et al. Anchorage and retentive effects of a bisphosphonate (AHBuBP) on tooth movements in rats. Am. J. Orthod. Dentofacial Orthop., v.106, n.3, p.279-89, Sept. 1994.

37. IGARASHI, K. et al. Inhibitory effect of the topical administration of a bisphosphonate (risedronate) on root resorption incident to orthodontic tooth movement in rats. J. Dent. Res., v.75, n.9, p.1644-9, Sept. 1996.

38. IKAWA, M. et al. The effect of short-term tooth intrusion on human pulpal blood flow easured by laser Doppler flowmetry. Arch. Oral Biol., v.46, n.9, p.781-7, Sept. 2001.

39. JERRARD, H. G.; McNEILL, D.B. Dictionary of scientific units. 6ed. London, Ed. Chapman \& Hill, 1992.

40. KAYHAN, F.; KUCUKKELES, N.; DEMIREL, D. A histologic and histomorphometric evaluation of pulpal reactions following rapid palatal expansion. Am. J. Orthod. Dentofacial Orthop., v.117, n.4, p.465-73, Apr. 2000.

41. KIM, K. J. et al. A novel bisphophonate inhibits inflammatory bone resorption in rat osteolysis model with continuous infusion of polyethylene particles. J. Orthod. Res., v.20, n.3, p.499-505, 2002.

42. KIM, T. W. et al. An ultrastructural study of the effects of bisphosphonate administration on osteoclastic bone resorption during relapse of experimentally moved rat molars. Am. J. Orthod. Dentofacial Orthop., v.115, n.6, p.645-53, June 1999.

43. KOGURE, T.; YAMADA, S.; TUNODA, T.; Über die na menschlichen Zälinen angewandten Regulierungskräfte im ZUsammenhang mit ihren patho-histologischen Varänderungen. Fortschr, Orthodont., v.3, p.544-51, 1933 apud STENVIK, A.; MJÖR, I. A. Pulp and dentine reactions to experimental tooth intrusion. A histologic study of the initial changes. Am. J. Orthod., v.57, n.4, p.370-85, Apr. 1970 .

44. KVINNSLAND, S.; HEYERAAS, K.; OFJORD E.S. Effect of experimental tooth movement on periodontal and pulpal blood flow. Eur. J. Orthod., v.11, n.3, p.200-5, Aug. 1989.

45. KYOMEN, S.; TANNE, K. Influences of aging changes in proliferative rate of PDL cells during experimental tooth movement in rats. Angle Orthod., v.67, n.1, p.67-72, 1997.

46. LABART, W. A. et al. The effect of orthodontic forces on pulp respiration in the rat incisor. J. Endod., v.6, n.9, p.724-7, Sept. 1980.

47. LANDAY, M.A.; SELTZER, S. The effects of excessive occlusal force on the pulp. Oral Surg. Oral Med. Oral Pathol., v.32, n.4, p.623-38, Oct. 1971. 
48. LANDIS, J. R.; KOCH, G. G. The measurement of observer agreement for categorical data. Biometrics., v.33, n.1, p.159-74, Mar. 1977.

49. LANGELAND, K. Histologia e fisiologia da polpa. In Cohen, S.; Burns, R. C. Caminhos da Polpa, 2ed. Rio de Janeiro; Guanabara Koogan, 1982, Cap.10, p. 196-282.

50. LEIKER, B. J. et al. The effects of exogenous prostaglandins on orthodontic tooth movement in rats. Am. J. Orthod. Dentofacial Orthop., v.108, n.4, p.380-8, Oct. 1995.

51. MACAPANPAN, L. C. et al. Early tissue changes following tooth movement in rats. Angle Orthodont., v.24, n.2, p.79-95, 1954.

52. MARSHALL, J.A. A study of bone and tooth changes incident to experimental tooth movement and its application to orthodontic practice. Int. J. Orthod. Dent. Child., v.19, n.1, p.1-17, 1933 apud MARSHALL, J.A. A study of bone and tooth changes incident to experimental tooth movement and its application to orthodontic practice. Int. J. Orthod. Dent. Child., v.19, n.1, p.1-17, 1933.

53. MARTINS-ORTIZ, M.F. Influência dos bisfosfonatos na movimentação dentária induzida, na freqüência e nas dimensões das reabsorções radiculares associadas. Bauru, 2004. 188p. Tese (Doutorado) - Faculdade de Odontologia de Bauru, Universidade de São Paulo.

54. MATOS, J.L.B. Calcificações nas cavidades pulpares em dentes de pacientes tratados ortodonticamente. Rio de Janeiro, 1983. 61p. Dissertação (Mestrado) - Faculdade de Odontologia, Universidade Federal do Rio de Janeiro.

55. MAZZIEIRO, E. T. Bifosfonato e movimentação dentária induzida: avaliação microscópica de seus efeitos. Bauru, 1999. 154p. Tese (Doutorado) - Faculdade de Odontologia de Bauru, Universidade de São Paulo.

56. McDONALD, F.; PITT FORD T.R. Blood flow changes in permanent maxillary canines during retraction. Eur. J. Orthod.; v.16, n.1, p.1-9, Feb. 1994.

57. MELSEN B. Tissue reaction following application of extrusive and intrusive forces to teeth in adult monkeys. Am. J. Orthod., v.89, n.6, p.469-75, June 1986.

58. MENDONÇA, M.R. et al. Avaliação histológica da polpa dental humana após o emprego da força ortodôntica de intrusão. Ortodontia, v.29, n.1, p.13-18, jan/abr. 1996.

59. MJÖR, I. A. Pulp-dentin biology in restorative dentistry. Mjör New Malden, Chicago, Quintessence, 2002.

60. MJÖR, I.A.; STENVIK A. Microradiography and histology of decalcified human teeth following experimental intrusion; with emphasis on resorption. Arch. Oral Biol., v.14, n.12, p.1355-64, Dec. 1969.

61. MOSS-SALENTIJN, L.; HENDRICKS-KLYVERT, M. Calcified structures in human dental pulps. J. Endod., v.14, n.4, p.184-9, Apr. 1988.

62. MOSTAFA, Y.A.; ISKANDER, K.G.; EL-MANGOURY, N.H. Iatrogenic pulpal reactions to orthodontic extrusion. Am. J. Orthod. Dentofacial Orthop., v.99, n.1, p.30-4, Jan. 1991.

63. NIXON, C.E. et al. Histomorphometric study of dental pulp during orthodontic tooth movement. J. Endod., v.19, n.1, p.13-6, Jan. 1993. 
64. NOREVALL, L. I.; FORSGREN, S.; MATSSON, L. Expression of neuropeptides (CGRP, substance P) during and after orthodontic tooth movement in the rat. Eur. J. Orthod., v.17, n.4, p.311-25, Aug. 1995.

65. ODA, M. Contribuição ao estudo histomorfológico das reações pulpares in vivo em decorrência da aplicação de forças ortodônticas. São Paulo, 1993. 73p. Tese (Doutorado) - Faculdade de Odontologia da Universidade de São Paulo.

66. OPPENHEIM, A. Biologic orthodontic therapy and reality. Angle Orthod., v.7, p.58-9, 1937.

67. OPPENHEIM, A. Biologic orthodontic therapy and reality. Angle Orthod., v.6, p.153, 1936.

68. OPPENHEIM, A. Biologisch-orthodontisch therapie und wirklichkeit. Wien, Urban und Schwarzenberg, 1936 apud MARSHALL, J.A. A study of bone and tooth changes incident to experimental tooth movement and its application to orthodontic practice. Int. J. Orthod. Dent. Child., v.19, n.1, p.1-17, 1933.

69. OPPENHEIM, A. Human tissue response to orthodontic intervention of short and long duration. Am. J. Orthod., v.28, p.263-301, 1942.

70. OPPENHEIM, A. Tissue changes particulary of the bone. Trans. Europ. Orthodont. Soc., v.8, n.11, 1911 apud DAVIDOVITCH, Z. Tooth movement. Crit. Rev. Oral Biol. Méd., v.2, n.4, p.411-50, 1991.

71. ORBAN, B. Odontoblastes in the dentinal tubule. J. Dent. Res., v.20, n.4, 553-7 Aug. 1941.

72. PEREIRA, A. C. Influência da gravidez e dos anticoncepcionais na reabsorção radicular na remodelação óssea, conseqüente a movimentação dentária induzida. Avaliação microscópica. Bauru, 1995. 141p. Dissertação (Mestrado) - Faculdade de Odontologia de Bauru, Universidade de São Paulo.

73. PEREIRA, A. C. Influência da ovariectomia na movimentação dentária induzida: Avaliação microscópica. Bauru, 2000. 127p. Tese (Doutorado) - Faculdade de Odontologia de Bauru, Universidade de São Paulo.

74. PEREIRA, W. Jr. Dentes movimentados ortodonticamente podem ter sua polpa prejudicas? Revista da APCD, V.51, n.1, p.90, Jan./Fev. 1997.

75. PEREIRA, W. Jr.; VAROLI, O.J. Alterações pulpares em resposta à movimentação ortodôntica dos dentes: Calcificações pulpares - estudo radiográfico longitudinal. Rev. Odontol. Univ. São Paulo., v.9, n.4, p.265-77, out./dez. 1995.

76. PERINETTI, G. et al.Aspartate aminotransferase activity in pulp of orthodontically treated teeth. Am. J. Orthod. Dentofacial Orthop., v.125, n.1, p.88-92, Jan. 2004.

77. POPP, T.W.; ARTUN, J.; LINGE, L. Pulpal response to orthodontic tooth movement in adolescents: a radiographic study. Am. J. Orthod. Dentofacial. Orthop., v.101, n.3, p.228-33, Mar. 1992.

78. POTER, G. The norway rat (Rattus norvegicus). In: LANNE-PETTER, W. et al. The UFAW handbook on the care and manegement of laboratory animals. 3ed. London, Livingstone, 1967. Cap.22, p.353-90.

79. PRIETSCH, J.R. et al. Reações pulpares de dentes de primatas jovens (Cebus apella), submetidos a disjunção palatal. Ortodontia Gaúcha, v.3, n.2, p.77-84, jul./dez. 1999. 
80. REITAN, K.; KVAM, E. Comparative behavior of human and animal tissue during experimental tooth movement. Angle Orthod., v.41, n.1, p.1-14, Jan. 1971.

81. SALES, C. L. F. Avaliação dos efeitos do glutaraldeido sobre os tecidos pulpares e periapicais após pulpotomias em molares de ratos: estudo microscópico. Bauru, 1989, 92p. Dissertação (Mestrado) - Faculdade de Odontologia de Bauru, Universidade de São Paulo.

82. SANDSTEDT, C. 1901. [Nagra bigrag til tandregleringens teori, P. A. Nordstedt \& Sttoner, Stockholm] apud DAVIDOVITCH, Z. Tooth movement. Crit. Rev. Oral Biol. Méd., v.2, n.4, p.411-50, 1991.

83. SANO, Y. et al. The effect of continuous intrusive force on human pulpal blood flow. Eur. J. Orthod., v.24, n.2, p.159-66, Apr. 2002.

84. SATO, M. et al. Bisphosphonate action. Alendronate localization in rat bone and effects on osteoclast ultrastructure. J. Clin. Invest., v.88, n.6, p.2095-105, Dec. 1991.

85. SATO, M. et al. Bisphosphonate administration alters subcellular localization of vacuolar-type $\mathrm{H}(+)$-ATPase and cathepsin $\mathrm{K}$ in osteoclasts during experimental movement of rat molars. Anat. Rec., v.260, n.1, p.72-80, Sept. 2000.

86. SCHOUR, I.; MASSLER, M. The teeth. In: FARRIS, E. J.; GRIFFITH, J. Q. The rat in laboratory investigation. 2ed. New York, Hafner Publishing Co., 1963, Cap.6, p.104-65.

87. SHAFER, W.G.; HINE, M. K.; LEVY, B. M. Tratado de patologia Bucal. 4ed. Rio de Janeiro, Interamericana, 1985.

88. SPECTOR, J.K.; ROTHENHAUS, B.; HERMAN, R.I. Pulpal necrosis following orthodontic therapy. Report of two cases. N. Y. State Dent. J., v.40, n.1, p.30-2, Jan. 1974.

89. STANLEY H. R. Pulp response to dental techniques and materials. Dental Clin. North. Am., v.15, n.1, p.115-26, jan. 1971.

90. STANLEY, H.R. Design for a human pulp study. I. Oral Surg. Oral Med. Oral Pathol., v.25, n.4, p.633-47, Apr. 1968.

91. STANLEY, H.R. Design for a human pulp study. II. Oral Surg. Oral Med. Oral Pathol., v.25, n.5, p.756-64. May 1968.

92. STANLEY, H.R. et al. Ischemic infarction of the pulp: sequential degenerative changes of the pulp after traumatic injury. J. Endod., v.4, n.11, p.325-35, Nov. 1978.

93. STANLEY, H.R. Methods and criteria in evaluation of dentin and pulp response. Int. Dent. J., v.20, n.3, p.507-27, Sept. 1970.

94. STANLEY, H.R.Jr.; SWERDLOW, H. Aspiration of cells into dentinal tubules? Oral Surg. Oral Med. Oral Pathol., v.11, n.9, p.1007-17, Sept. 1958.

95. STENVIK, A. Pulp and dentine reactions to experimental tooth intrusion: A histologic study - long-term effects. Rep. Congr. Eur. Orthod. Soc., p.449-64, 1970.

96. STENVIK, A.; MJÖR, I. A. Pulp and dentine reactions to experimental tooth intrusion. A histologic study of the initial changes. Am. J. Orthod., v.57, n.4, p.370-85, Apr. 1970. 
97. STENVIK, A.; MJÖR, I. A. The effect of experimental tooth intrusion on pulp and dentine. Oral Surg. Oral Med. Oral Pathol., v.32, n.4, p.639-48, Oct. 1971.

98. STRANG, R.H.W. A textbook of orthodontia. Philadelphia, Lea and Febiger, 1943. p.323.

99. SÜBAY, R.K. et al. Response of human pulpal tissue to orthodontic extrusive applications. J. Endod., v.27, n.8, p.508-11, Aug. 2001.

100. TIMMS, D. J.; MOSS, J. P. An histological investigation into the effects of rapid maxillary expansion on the teeth and their supporting tissues. Trans. Eur. Orthod. Soc., p.263-71, 1971.

101. TOMS, S. R.; EBERHARDT, A. W. A nonlinear finite element analysis of the periodontal ligament under orthodontic tooth loading. Am. J. Orthod. Dentofacial Orthop., v.123, n.6, p.657-65, June 2003.

102. UNTERSEHER, R.E. et al. The response of human pulp tissue after orthodontic force application. Am. J. Orthod. Dentofacial Orthop., v.92, n.3, p.220-224, Sept. 1987.

103. VALLADARES NETO, J.. Análise microscópica do complexo dentinopulpar e da superfície radicular externa após expansão rápida da maxila em adolescentes. Goiania, 2000. 196p. Dissertação (Mestrado) -Universidade Federal de Goiás.

104. VASCOCELOS et al. A histological study of tooth movement in rats under contraceptive use. In: DAVIDIVITCH, Z.; MAH, J. Biologicam mechanisms of tooth eruption, resorption and replacement by implants. Alabama, Harvard Society for the Advancement of Orthodontics, 1998.

105. VASCONCELOS, M.H.F. Análise morfológica comparativa do periodonto de sustentação submetido a forças biologicamente excessivas, em ratas adultas sem e sob o uso de anticoncepcionais e ratas prenhes. Bauru, 1996. 148p. Dissertação (Mestrado) - Faculdade de Odontologia de Bauru, Universidade de São Paulo.

106. VERNA, C.; DALSTRA, M.; MELSEN, B. The rate and the type of orthodontic tooth movement is influenced by bone turnover in a rat model. Eur. J. Orthod., v.22, n.4, p.343-52, Aug. 2000.

107. VERNA, C.; DALSTRA, M.; MELSEN, B. Tissue reaction to orthodontic tooth movement in different bone turnover conditions. Orthod. Craniofac. Res., v.6, n.3, p.155-63, Aug. 2003.

108. VILLA, P. A. et al. Pulp-dentine complex changes and root resorption during intrusive orthodontic tooth movement in patients prescribed nabumetone. J. Endod., v.31, n.1, p.61-6, Jan. 2005.

109. WALDO, C. M.; ROTHBLATT, J. M. Histologic response to tooth movement in the laboratory rat; procedure and preliminary observations. J. Dent. Res., v.33, n.4, p.481-6, Aug. 1954.

110. WALKER, J.A.Jr. et al. The enkephalin response in human tooth pulp to orthodontic force. Am. J. Orthod. Dentofacial Orthop., v.92, n.1, p.9-16, July 1987.

111. WOLOSHYN, H. et al. Pulpal and periodontal reactions to orthodontic alignment of palatally impacted canines. Angle Orthod., v.64, n.4, p.257-64, 1994.

112. WONG, V.S. et al. Tooth movement and vascularity of the dental pulp: a pilot study. Aust. Orthod. J., v.15, n.4, p.246-50, Apr. 1999. 
113. YOKOYA, K.; SASAKI, T.; SHIBASAKI, Y. Distributional changes of osteoclasts and preosteoclastic cells in periodontal tissues during experimental tooth movement as revealed by quantitative immunohistochemistry of H(+)-ATPase. J. Dent. Res., v.76, n.1, p.580-7, Jan. 1997.

114. ZIMRING, J.F.; ISAACSON, R.J. Forces produced by rapid maxillary expansion. 3. forces present during retention. Angle Orthod., 1965 Jul;35:178-86. 
Elbstriact 
Abstract

\section{Dentin-pulp analysis of induced dental movement in rats}

The effects of induced tooth movement on the pulp of Wistar rats were analyzed through light microscopy in 49 first upper molars. The orthodontic appliance consisted of a coil spring moving the fist left molar foreword supported by the incisor. The sample was divided into 4 groups according to the period of observation. The control group consisted of 10 animals without any orthodontic movement. The other 39 rats were evaluated after: 1, 2, 3, 4, 5, 6 and 7 days of dental movement. The efficiency of induced tooth movement was verified trough the expected classic periodontal phenomena, such as segmental hyalinization of the ligament, bone resorption and even dental resorption, due to intense forces on the distal root. The dentin-pulp complex did not demonstrate any morphological alteration which indicated effects of induced tooth movement. 